Supporting Materials for

\title{
Synthesis of Imino-Amido Hafnium and Zirconium Complexes from Bis-Imine Ligands. A New Family of Olefin Polymerization Catalysts.
}

Philip De Waele, Brian A. Jazdzewski, Jerzy Klosin*, Rex E. Murray', Curt N. Theriault and Paul C. Vosejpka

Corporate R\&D, The Dow Chemical Company, 1776 Building, Midland, MI 48674.

jklosin@dow.com

Jeffrey L. Petersen

C. Eugene Bennett Department of Chemistry, West Virginia University, Morgantown, WV 26506-6045.

Contents:

1. Polymerization procedure and polymer analysis

2. Experimental procedures and NMR spectra

3. Decomposition kinetics of 5 at $50-80{ }^{\circ} \mathrm{C}$.

4. ORTEP drawings and single crystal X-ray data for $\mathbf{5 , 7 , 8}$ and 13.

1. Current address: Chevron Phillips Chemical Company, West Highway 60, Bartlesville, OK 74004. 
General Considerations. All syntheses and manipulations of air-sensitive materials were carried out in an inert atmosphere (nitrogen or argon) glove box. Solvents were first saturated with nitrogen and then dried by passage through activated alumina and Q- $5^{\mathrm{TM}}$ catalyst prior to use. Deuterated NMR solvents (toluene- $\mathrm{d}_{8}, \mathrm{C}_{6} \mathrm{D}_{6}$ ) were dried over sodium/potassium alloy and filtered prior to use unless otherwise noted. NMR spectra were recorded on Varian INOVA 300 and Mercury 300 (FT $300 \mathrm{MHz},{ }^{1} \mathrm{H} ; 75 \mathrm{MHz},{ }^{13} \mathrm{C}$ ) spectrometers. ${ }^{1} \mathrm{H}$ NMR data are reported as follows: chemical shift (multiplicity $(\mathrm{br}=$ broad, $\mathrm{s}=$ singlet, $\mathrm{d}=$ doublet, $\mathrm{t}=$ triplet, $\mathrm{q}=$ quartet, $\mathrm{p}$ $=$ pentet, and $\mathrm{m}=$ multiplet), integration and assignment). Chemical shifts for ${ }^{1} \mathrm{H}$ NMR data are reported in ppm downfield from internal tetramethylsilane (TMS, $\delta$ scale) using residual protons in the deuterated solvents $\left(\mathrm{C}_{6} \mathrm{D}_{6}, 7.15 \mathrm{ppm}, \mathrm{C}_{6} \mathrm{D}_{5} \mathrm{CD}_{3}, 2.09 \mathrm{ppm}\right)$ as references. ${ }^{13} \mathrm{C}$ NMR data were determined with ${ }^{1} \mathrm{H}$ decoupling and the chemical shifts are reported in ppm vs tetramethylsilane $\left(\mathrm{C}_{6} \mathrm{D}_{6}, 128 \mathrm{ppm}, \mathrm{C}_{6} \mathrm{D}_{5} \mathrm{CD}_{3}, 20.4 \mathrm{ppm}\right)$. [HNMe $\left.\left(\mathrm{C}_{18} \mathrm{H}_{37}\right)_{2}\right]\left[\mathrm{B}\left(\mathrm{C}_{6} \mathrm{~F}_{5}\right)_{4}\right]^{2},{ }^{2} \mathrm{~N}, \mathrm{~N}$ bis(2,6-diisopropylpenyl)-1,2-ethaneimine ${ }^{3} \quad$ and N,N'-bis(2,6-diisopropylphenyl)-2,3butanediimine $^{4}$ were prepared according to literature procedures. Mass spectra (ElectroSpray) were recorded on a QTOF-2 (s/n UC-175) mass spectrometer. Elemental analyses were performed by University of Michigan analytical services.

\section{Ethylene-1-octene Polymerization Procedures and Polymer Characterizations.}

Ethylene-1-octene copolymerization. A 2-liter Parr reactor was used in the polymerizations. All feeds were passed through columns of alumina and Q-5 ${ }^{\mathrm{TM}}$ catalyst (available from Englehardt Chemicals Inc.) prior to introduction into the reactor. Catalyst and cocatalyst (activator) solutions were handled in the glove box. A stirred 2-liter reactor was charged with about $533 \mathrm{~g}$ of mixed alkanes solvent and $250 \mathrm{~g}$ of 1-octene comonomer. Hydrogen was added as a molecular weight control agent by differential pressure expansion from a $75 \mathrm{~mL}$ addition tank at $300 \mathrm{psi}(2070 \mathrm{kPa})$. The reactor contents were heated to the polymerization temperature of $120{ }^{\circ} \mathrm{C}$ and saturated with ethylene at $460 \mathrm{psig}$ (3.4 MPa). Preparation of catalyst solution: To a vial was added $100 \mu \mathrm{l}$ of $0.1 \mathrm{M}$ MMAO toluene solution

2. Rosen, R. K.; Vanderlende, D. D. PCT Int. Application WO 9735893, 1997 (Dow Chemical Company)

3. Jinkun, H.; Nolan, S. P. J. Am. Chem. Soc. 1999, 121, 9889-9890.

4. Tom Dieck, H.; Svoboda, M.; Greiser, T. Z. Naturforsch., B: Chem. Sci. 1981, 36B, 823-832 
$(10 \mu \mathrm{mol})$ followed by addition of cocatalyst $\left(\left[\mathrm{HNMe}\left(\mathrm{C}_{18} \mathrm{H}_{37}\right)_{2}\right]\left[\mathrm{B}\left(\mathrm{C}_{6} \mathrm{~F}_{5}\right)_{4}\right]\right)(0.005 \mathrm{M}$ solution in toluene) followed by addition of catalyst solution ( $0.005 \mathrm{M}$ solution in toluene). Solution was mixed for a few seconds and then transferred to a catalyst addition tank and injected into the reactor. The polymerization conditions were maintained for $15 \mathrm{~min}$ with ethylene added on demand. Heat was continuously removed from the reaction through an internal cooling coil. The resulting solution was removed from the reactor, quenched with isopropyl alcohol, and stabilized by addition of $10 \mathrm{~mL}$ of a toluene solution containing approximately $67 \mathrm{mg}$ of a hindered phenol antioxidant (Irganox ${ }^{\mathrm{TM}} 1010$ from Ciba Geigy Corporation) and $133 \mathrm{mg}$ of a phosphorus stabilizer (Irgafos ${ }^{\mathrm{TM}} 168$ from Ciba Geigy Corporation). Between polymerization runs a wash cycle was conducted in which $850 \mathrm{~g}$ of mixed alkanes were added to the reactor and the reactor was heated to $150{ }^{\circ} \mathrm{C}$. The reactor was then emptied of the heated solvent immediately before beginning a new polymerization run. Polymers were recovered by drying for about $12 \mathrm{~h}$ in a temperature ramped vacuum oven with a final set point of $140{ }^{\circ} \mathrm{C}$. Melting and crystallization temperatures of polymers were measured by differential scanning calorimetry (DSC 2910, TA Instruments, Inc.). Samples were first heated from room temperature to $180{ }^{\circ} \mathrm{C}$ at $10{ }^{\circ} \mathrm{C} / \mathrm{min}$. After being held at this temperature for 2-4 min, the samples were cooled to $-40{ }^{\circ} \mathrm{C}$ at $10^{\circ} \mathrm{C}$ /min, held for 2-4 min, and were then heated to $160{ }^{\circ} \mathrm{C}$. Molecular weight and PDI were determined using a Symyx ${ }^{\mathrm{TM}}$ Rapid Gel Permeation calorimeter. Samples were prepared using $30 \mathrm{mg}$ of polymer per $1 \mathrm{~mL}$ of 1,2,4 trichlorobenzene (stabilized with BHT), heated and shaken at $160{ }^{\circ} \mathrm{C}$ for $2 \mathrm{~h}$. The samples were further diluted with TCB to obtain a $1 \mathrm{mg}$ polymer to $1 \mathrm{~mL}$ TCB solution. Octene content (mol \%) in EO copolymers was determined using ${ }^{1} \mathrm{H}$ NMR spectroscopy. About $10 \mathrm{mg}$ of polymer was dissolved in $0.7 \mathrm{~mL}$ of $\mathrm{C}_{2} \mathrm{D}_{2} \mathrm{Cl}_{4}$ at $130-150{ }^{\circ} \mathrm{C}$. Spectra were obtained at $120{ }^{\circ} \mathrm{C}$ using delay time of $25 \mathrm{sec}$. and acquisition time of $3 \mathrm{sec}$. and pulse angle of $66 \mathrm{deg}$. 


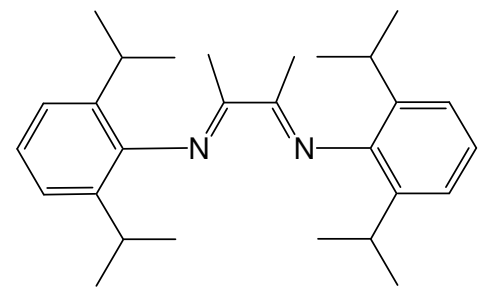

4

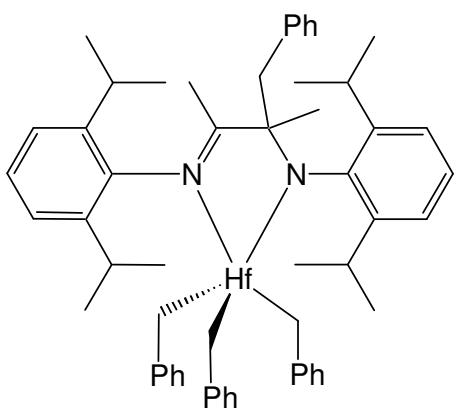

5

Preparation of 5. NMR tube experiment: To a vial containing $0.089 \mathrm{~g}(0.22 \mathrm{mmol})$ of N,N'bis(2,6-diisopropylphenyl)-2,3-butanediimine and $0.119 \mathrm{~g}(0.22 \mathrm{mmol})$ of $\mathrm{Hf}\left(\mathrm{CH}_{2} \mathrm{Ph}\right)_{4}$ was added $0.8 \mathrm{~mL}$ of $\mathrm{C}_{6} \mathrm{D}_{6}$. Solution was then transferred to NMR tube. NMR taken after $15 \mathrm{~min}$ showed formation of about $15 \%$ of product. The next day proton NMR showed quantitative conversion to $\mathbf{5}$.

Preparative scale: To a $40 \mathrm{~mL}$ vial was added $2.00 \mathrm{~g}(3.68 \mathrm{mmol})$ of $\mathrm{Hf}\left(\mathrm{CH}_{2} \mathrm{Ph}\right)_{4}$ and $1.49 \mathrm{~g}$ (3.68 mmol) of N,N'-bis(2,6-diisopropylphenyl)-2,3-butanediimine followed by $8 \mathrm{~mL}$ of toluene to dissolve all reagents. The solution was stirred for $42 \mathrm{~h}$ at ambient temperature, yielding a dark orange solution. The solvent amount was reduced under reduced pressure to $4 \mathrm{~mL}$. During solvent removal a yellow solid appeared. Hexane was added $(25 \mathrm{~mL})$ to this suspension to induce further precipitation. After stirring for $10 \mathrm{~min}$ the solid was collected on the frit, washed with 20 $\mathrm{mL}$ of hexanes and dried under reduced pressure to give $2.55 \mathrm{~g}$ of product. The filtrate was stored overnight at $-30{ }^{\circ} \mathrm{C}$ causing the precipitation of additional solid. Upon workup (as above) a second crop of $0.3 \mathrm{~g}$ was isolated. Combined yield $2.85 \mathrm{~g}, 82 \%$. NMR spectra are shown on the next page. Crystals suitable for X-ray analysis were obtained by allowing a vial containing hexane wash to stand at ambient temperature overnight.

${ }^{1} \mathrm{H}\left(\mathrm{C}_{6} \mathrm{D}_{6}, 300 \mathrm{~Hz}, 23{ }^{\circ} \mathrm{C}\right) \delta 7.29\left(\mathrm{dd}, 1 \mathrm{H},{ }^{3} J_{\mathrm{H}-\mathrm{H}}=7.8 \mathrm{~Hz},{ }^{4} J_{\mathrm{H}-\mathrm{H}}=2.1 \mathrm{~Hz}\right), 7.24\left(\mathrm{t}, 1 \mathrm{H},{ }^{3} J_{\mathrm{H}-\mathrm{H}}=7.5\right.$ $\mathrm{Hz}), 7.16\left(\mathrm{dd}, 1 \mathrm{H},{ }^{3} J_{\mathrm{H}-\mathrm{H}}=7.2 \mathrm{~Hz},{ }^{4} J_{\mathrm{H}-\mathrm{H}}=1.8 \mathrm{~Hz}\right), 6.80\left(\mathrm{t}, 3 \mathrm{H},{ }^{3} J_{\mathrm{H}-\mathrm{H}}=7.5 \mathrm{~Hz}\right.$, para $\left.-\mathrm{CH}_{2} \mathrm{Ph}\right), 6.94-$ $7.14(\mathrm{~m}, 14 \mathrm{H}), 6.62\left(\mathrm{~d}, 6 \mathrm{H},{ }^{3} J_{\mathrm{H}-\mathrm{H}}=7.5 \mathrm{~Hz}\right.$, ortho- $\left.\mathrm{CH}_{2} \mathrm{Ph}\right), 3.83\left(\mathrm{~d}, 1 \mathrm{H},{ }^{2} J_{\mathrm{H}-\mathrm{H}}=13.5 \mathrm{~Hz}, \mathrm{C}-\right.$ $\mathrm{CH}_{2} \mathrm{Ph}$ ), 3.75 (septet, $\left.1 \mathrm{H},{ }^{3} J_{\mathrm{H}-\mathrm{H}}=6.6 \mathrm{~Hz}, \mathrm{CH}\left(\mathrm{CH}_{3}\right)_{3}\right), 3.53$ (septet, $1 \mathrm{H},{ }^{3} J_{\mathrm{H}-\mathrm{H}}=6.6 \mathrm{~Hz}$, $\left.\mathrm{C} H\left(\mathrm{CH}_{3}\right)_{3}\right), 3.42\left(\mathrm{~d}, 1 \mathrm{H},{ }^{2} J_{\mathrm{H}-\mathrm{H}}=13.5 \mathrm{~Hz}, \mathrm{C}-\mathrm{CH}_{2} \mathrm{Ph}\right), 3.04$ (septet, $2 \mathrm{H},{ }^{3} J_{\mathrm{H}-\mathrm{H}}=6.6 \mathrm{~Hz}$, $\left.\mathrm{CH}\left(\mathrm{CH}_{3}\right)_{2}\right), 2.34\left(\mathrm{~d}, 3 \mathrm{H},{ }^{2} J_{\mathrm{H}-\mathrm{H}}=11.7 \mathrm{~Hz}, \mathrm{HfCH}_{2} \mathrm{Ph}\right), 2.21\left(\mathrm{~d}, 3 \mathrm{H},{ }^{2} J_{\mathrm{H}-\mathrm{H}}=11.7 \mathrm{~Hz}, \mathrm{HfCH}{ }_{2} \mathrm{Ph}\right)$, $1.33\left(\mathrm{~d}, 3 \mathrm{H},{ }^{3} J_{\mathrm{H}-\mathrm{H}}=6.9 \mathrm{~Hz}, \mathrm{CH}\left(\mathrm{CH}_{3}\right)_{2}\right), 1.32\left(\mathrm{~d}, 6 \mathrm{H},{ }^{3} J_{\mathrm{H}-\mathrm{H}}=6.9 \mathrm{~Hz}, \mathrm{CH}\left(\mathrm{CH}_{3}\right)_{2}\right), 1.23\left(\mathrm{~d}, 3 \mathrm{H},{ }^{3} J_{\mathrm{H}-}\right.$ 
$\left.\mathrm{H}=6.9 \mathrm{~Hz}, \mathrm{CH}\left(\mathrm{CH}_{3}\right)_{2}\right), 1.18\left(\mathrm{~d}, 3 \mathrm{H},{ }^{3} J_{\mathrm{H}-\mathrm{H}}=6.6 \mathrm{~Hz}, \mathrm{CH}\left(\mathrm{CH}_{3}\right)_{2}\right), 1.11\left(\mathrm{~d}, 3 \mathrm{H},{ }^{3} J_{\mathrm{H}-\mathrm{H}}=6.6 \mathrm{~Hz}\right.$, $\left.\mathrm{CH}\left(\mathrm{CH}_{3}\right)_{2}\right), 1.06\left(\mathrm{~d}, 3 \mathrm{H},{ }^{3} \mathrm{~J}_{\mathrm{H}-\mathrm{H}}=6.9 \mathrm{~Hz}, \mathrm{CH}\left(\mathrm{CH}_{3}\right)_{2}\right), 1.01\left(\mathrm{~s}, 3 \mathrm{H}, \mathrm{CH}_{3}\right), 0.85\left(\mathrm{~s}, 3 \mathrm{H}, \mathrm{CH}_{3}\right), 0.84$ $\left(\mathrm{d}, 3 \mathrm{H},{ }^{3} J_{\mathrm{H}-\mathrm{H}}=6.6 \mathrm{~Hz}, \mathrm{CH}\left(\mathrm{CH}_{3}\right)_{2}\right) .{ }^{13} \mathrm{C}\left\{{ }^{1} \mathrm{H}\right\}\left(\mathrm{C}_{6} \mathrm{D}_{6}, 75 \mathrm{~Hz}, 23{ }^{\circ} \mathrm{C}\right) \delta 198.25(\mathrm{~N}=\mathrm{C}), 148.11$ (quat.), 148.04 (quat.), 147.89 (quat.), 146.11 (quat.), 143.17 (quat.), 140.64 (quat.), 140.24 (quat.), 138.13 (quat.), $130.90(\mathrm{CH}), 128.54(\mathrm{CH}), 128.41(\mathrm{CH}), 127.83(\mathrm{CH}), 127.21(\mathrm{CH})$, $126.48(\mathrm{CH}), 126.21(\mathrm{CH}), 125.60(\mathrm{CH}), 125.56(\mathrm{CH}), 124.73(\mathrm{CH}), 89.20$ (br. s. $v_{1 / 2}=37 \mathrm{~Hz}$, $\left.\mathrm{Hf}\left(\mathrm{CH}_{2} \mathrm{Ph}\right)_{3}\right), 78.21$ (quat.), $54.45\left(\mathrm{C}-\mathrm{CH}_{2} \mathrm{Ph}\right), 29.92(\mathrm{CH}), 28.79$ (2 carbons, $\left.\mathrm{CH}\right), 28.02(\mathrm{CH})$, $27.67\left(\mathrm{CH}_{3}\right), 26.51\left(\mathrm{CH}_{3}\right), 26.35\left(\mathrm{CH}_{3}\right), 26.14\left(\mathrm{CH}_{3}\right), 25.77\left(\mathrm{CH}_{3}\right), 24.99\left(\mathrm{CH}_{3}\right), 24.70\left(\mathrm{CH}_{3}\right)$, $24.23\left(\mathrm{CH}_{3}\right), 23.15\left(\mathrm{CH}_{3}\right), 22.62\left(\mathrm{CH}_{3}\right)$.

Peak assignments were facilitated by HSQC, COSY and NOESY spectra.

Anal. Calcd for $\mathrm{C}_{56} \mathrm{H}_{68} \mathrm{HfN}_{2}$ : C, 70.98; H, 7.23; N, 2.96. Found: C, 70.50; H, 7.14; N, 2.84 . 
Figure $1 .{ }^{1} \mathrm{H}$ and APT spectra of 5.
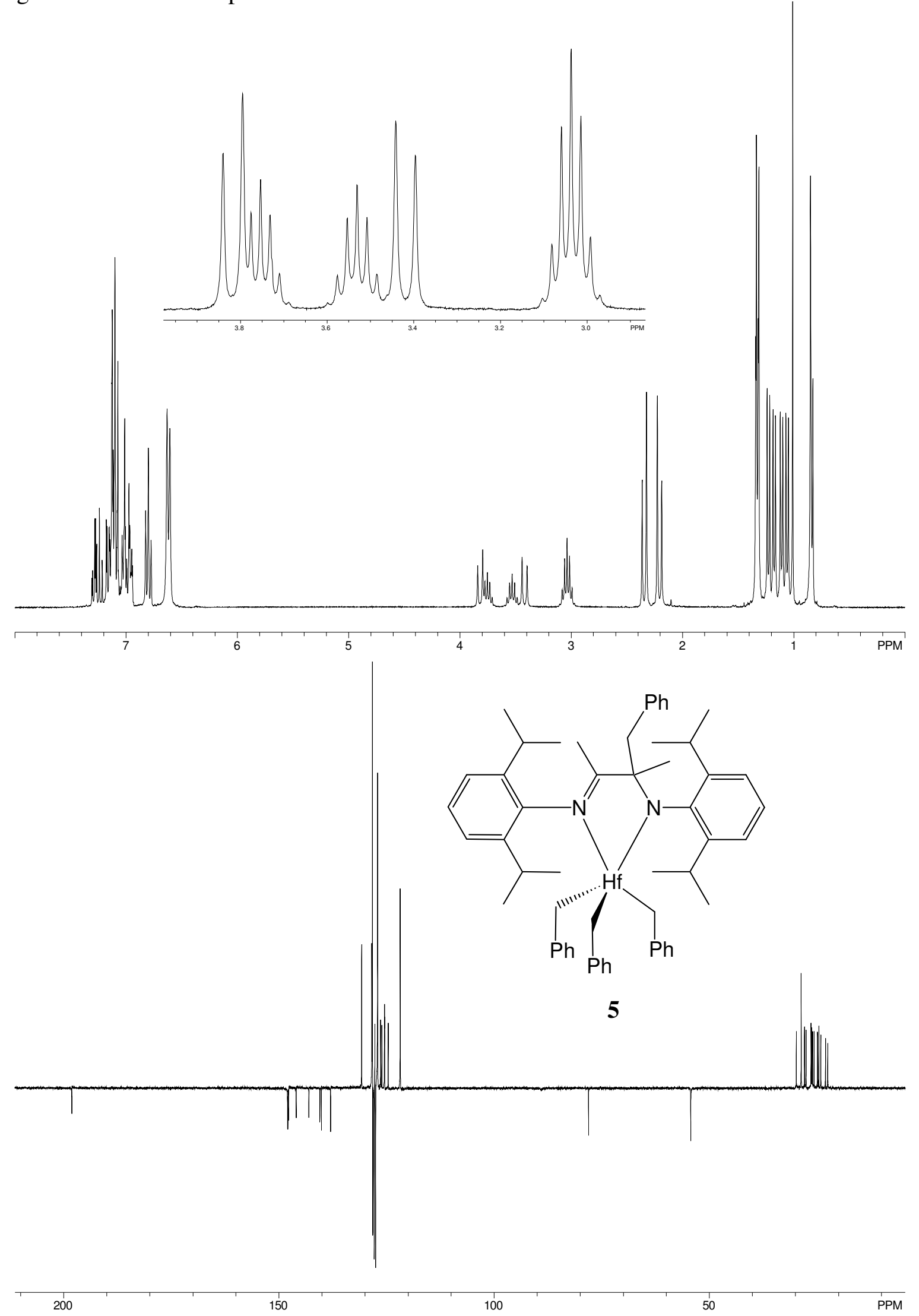
Figure 2. ${ }^{1} \mathrm{H}$ NMR spectra of 5 after $5 \mathrm{~min}$ (top) and $14 \mathrm{~h}$ (bottom) of heating at $70.5{ }^{\circ} \mathrm{C}$.

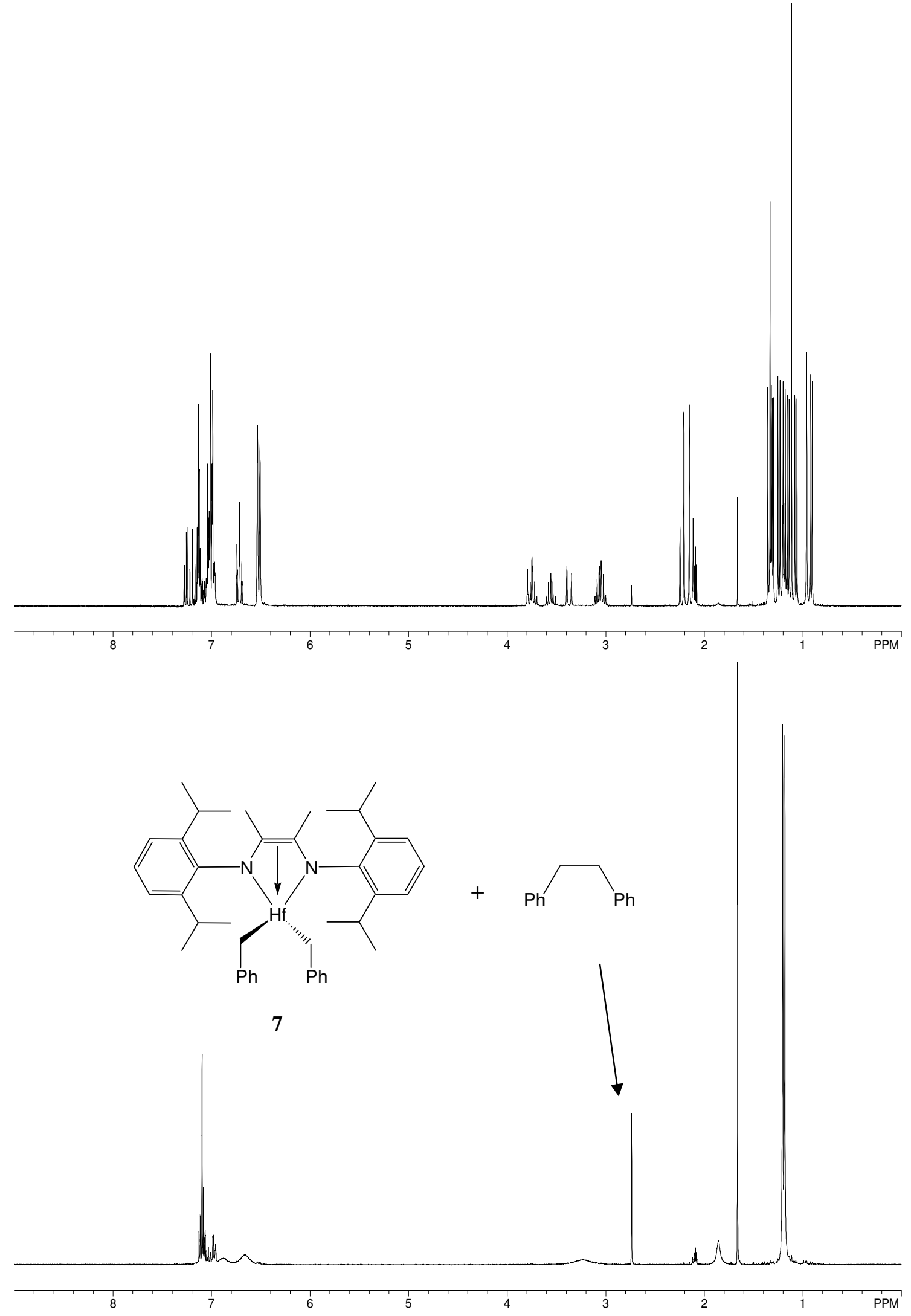




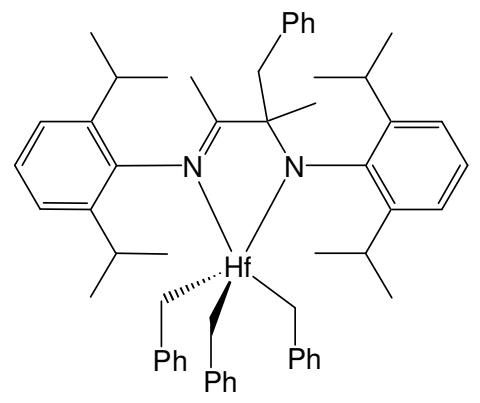

5 $\underset{\text { overnight }}{\stackrel{80{ }^{\circ} \mathrm{C}}{\longrightarrow}}$

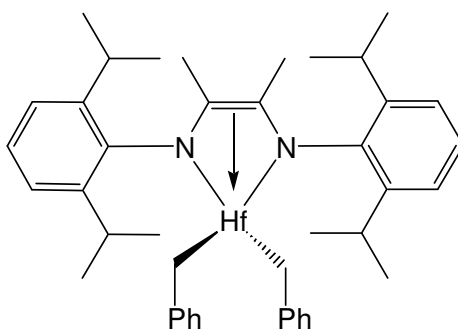

7

Preparation of 7. Complex $5(0.5 \mathrm{~g}, 0.53 \mathrm{mmol})$ was dissolved in $6 \mathrm{~mL}$ of toluene. The solution was heated for $18 \mathrm{~h}$ at $85{ }^{\circ} \mathrm{C}$. The solvent was removed under reduced pressure and the residue was dissolved in $7 \mathrm{~mL}$ of hexane and then filtered. The filtrate was stored for $3 \mathrm{~d}$ at $-30{ }^{\circ} \mathrm{C}$ causing the formation of yellow crystals. The mother liquor was decanted and the crystals were washed with cold hexanes $(2 \times 2 \mathrm{~mL})$ and then dried under reduced pressure to give $0.256 \mathrm{~g}$ of the product. Yield $63 \%$.

${ }^{1} \mathrm{H}$ NMR (toluene- $\left.d_{8}, 300 \mathrm{MHz}, \underline{-30}{ }^{\circ} \mathrm{C}\right) \delta 7.22\left(\mathrm{t},{ }^{3} J_{\mathrm{H}-\mathrm{H}}=7.5 \mathrm{~Hz}, 2 \mathrm{H}\right.$, meta- $\left.\mathrm{CH}_{2} \mathrm{Ph}\right), 7.10(\mathrm{~m}$, $6 \mathrm{H}), 7.04\left(\mathrm{~d},{ }^{3} J_{\mathrm{H}-\mathrm{H}}=7.2 \mathrm{~Hz}, 2 \mathrm{H}\right.$, ortho- $\left.\mathrm{CH}_{2} \mathrm{Ph}\right), 6.98\left(\mathrm{t},{ }^{3} J_{\mathrm{H}-\mathrm{H}}=7.2 \mathrm{~Hz}, 1 \mathrm{H}\right.$, para- $\left.\mathrm{CH}_{2} \mathrm{Ph}\right), 6.57(\mathrm{t}$, ${ }^{3} J_{\mathrm{H}-\mathrm{H}}=8.1 \mathrm{~Hz}, 2 \mathrm{H}$, meta- $\left.\mathrm{CH}_{2} \mathrm{Ph}\right), 6.30\left(\mathrm{~d},{ }^{3} J_{\mathrm{H}-\mathrm{H}}=7.2 \mathrm{~Hz}, 2 \mathrm{H}\right.$, ortho- $\left.\mathrm{CH}_{2} \mathrm{Ph}\right), 6.29\left(\mathrm{t},{ }^{3} J_{\mathrm{H}-\mathrm{H}}=7.2\right.$ $\mathrm{Hz}, 1 \mathrm{H}$, para- $\mathrm{CH}_{2} \mathrm{Ph}$ ), 3.69 (septet, $\left.{ }^{3} J_{\mathrm{H}-\mathrm{H}}=6.9 \mathrm{~Hz}, 2 \mathrm{H}, \mathrm{CH}\left(\mathrm{CH}_{3}\right)_{2}\right), 2.75$ (septet, ${ }^{3} J_{\mathrm{H}-\mathrm{H}}=6.6 \mathrm{~Hz}$, $\left.2 \mathrm{H}, \mathrm{CH}\left(\mathrm{CH}_{3}\right)_{2}\right), 2.00\left(\mathrm{~s}, 2 \mathrm{H}, \mathrm{CH}_{2} \mathrm{Ph}\right), 1.71\left(\mathrm{~s}, 2 \mathrm{H}, \mathrm{CH}_{2} \mathrm{Ph}\right), 1.59\left(\mathrm{~s}, 6 \mathrm{H}, \mathrm{CH}_{3}\right), 1.34\left(\mathrm{~d},{ }^{3} J_{\mathrm{H}-\mathrm{H}}=6.6\right.$ $\left.\mathrm{Hz}, 6 \mathrm{H}, \mathrm{CH}\left(\mathrm{CH}_{3}\right)_{2}\right), 1.24\left(\mathrm{~d},{ }^{3} J_{\mathrm{H}-\mathrm{H}}=6.6 \mathrm{~Hz}, 6 \mathrm{H}, \mathrm{CH}\left(\mathrm{CH}_{3}\right)_{2}\right), 1.20\left(\mathrm{~d},{ }^{3} J_{\mathrm{H}-\mathrm{H}}=6.9 \mathrm{~Hz}, 6 \mathrm{H}\right.$, $\left.\mathrm{CH}\left(\mathrm{CH}_{3}\right)_{2}\right), 1.13\left(\mathrm{~d},{ }^{3} J_{\mathrm{H}-\mathrm{H}}=6.9 \mathrm{~Hz}, 6 \mathrm{H}, \mathrm{CH}\left(\mathrm{CH}_{3}\right)_{2}\right)$.

${ }^{13} \mathrm{C}\left\{{ }^{1} \mathrm{H}\right\}$ NMR (toluene- $d_{8}, 75 \mathrm{MHz}, \underline{\left.-30{ }^{\circ} \mathrm{C}\right)} \delta 144.80$ (quat.), 143.97 (quat.), 143.30 (quat.), 143.25 (quat.), 139.60 (quat.), $131.39(\mathrm{CH}), 129.28(\mathrm{CH}), 127.37(\mathrm{CH}), 125.51(\mathrm{CH}), 125.23$ $(\mathrm{CH}), 123.85(\mathrm{CH}), 123.68(\mathrm{CH}), 123.62(\mathrm{CH}), 122.85(\mathrm{CH}), 109.64$ (quat.), $70.71\left(\mathrm{CH}_{2} \mathrm{Ph},{ }^{1} J_{\mathrm{CH}}\right.$ $=131.2 \mathrm{~Hz}), 65.40\left(\mathrm{CH}_{2} \mathrm{Ph},{ }^{1} J_{\mathrm{CH}}=121.3 \mathrm{~Hz}\right), 29.53\left(\mathrm{CH}\left(\mathrm{CH}_{3}\right)_{2}\right), 27.40\left(\mathrm{CH}_{\left.\left(\mathrm{CH}_{3}\right)_{2}\right), 25.42}\right.$ $\left(\mathrm{CH}\left(\mathrm{CH}_{3}\right)_{2}\right), 25.08\left(\mathrm{CH}\left(\mathrm{CH}_{3}\right)_{2}\right), 24.60\left(\mathrm{CH}\left(\mathrm{CH}_{3}\right)_{2}\right), 24.34\left(\mathrm{CH}\left(\mathrm{CH}_{3}\right)_{2}\right), 16.03\left(\mathrm{CH}_{3}\right)$.

${ }^{1} \mathrm{H}$ NMR (toluene- $d_{8}, 300 \mathrm{MHz}, \underline{\left.23{ }^{\circ} \mathrm{C}\right)} \delta 7.15$ (s. br., 2), 7.09 (m, 6H), 6.97 (s. br., 3H), 6.60 (s. br., 2H), 6.35 (s, br. 3H), 3.66 (s. br., $\left.2 \mathrm{H}, \mathrm{CH}\left(\mathrm{CH}_{3}\right)_{2}\right), 2.78$ (s. br., $\left.2 \mathrm{H}, \mathrm{CH}\left(\mathrm{CH}_{3}\right)_{2}\right), 2.02$ (s. br., $2 \mathrm{H}, \mathrm{CH}_{2} \mathrm{Ph}$ ), 1.69 (s. br., $2 \mathrm{H}, \mathrm{CH}_{2} \mathrm{Ph}$ ), 1.64 (s, 6H, $\mathrm{CH}_{3}$ ), 1.04-1.37 (br. with doublet in the middle, $\left.{ }^{3} J_{\mathrm{H}-\mathrm{H}}=6.6 \mathrm{~Hz}, 24 \mathrm{H}, \mathrm{CH}\left(\mathrm{CH}_{3}\right)_{2}\right)$.

${ }^{13} \mathrm{C}\left\{{ }^{1} \mathrm{H}\right\}$ NMR (toluene- $\left.d_{8}, 75 \mathrm{MHz}, \underline{23}{ }^{\circ} \mathrm{C}\right) \delta 144.95$ (quat.), 144.04 (br., quat.), 131.32 (br., $\mathrm{CH}$ ), 129.2 (br., $\mathrm{CH}$ ), 127.45 (br., $\mathrm{CH}), 125.71(\mathrm{CH}), 123.87$ (CH), 122.87 (br. $\mathrm{CH}), 109.88$ 
(quat.), 72.15 (br., $\mathrm{CH}_{2} \mathrm{Ph}$ ), 66.70 (br., $\mathrm{CH}_{2} \mathrm{Ph}$ ), 28.54 (br. $\left.\mathrm{CH}\left(\mathrm{CH}_{3}\right)_{2}\right)$, 27.61 (br. $\mathrm{CH}\left(\mathrm{CH}_{3}\right)_{2}$ ), 25.07 (br., $\left.\mathrm{CH}\left(\mathrm{CH}_{3}\right)_{2}\right), 16.10\left(\mathrm{CH}_{3}\right)$.

${ }^{1} \mathrm{H}$ NMR (toluene- $d_{8}, 300 \mathrm{MHz}, \underline{80}{ }^{\circ} \mathrm{C}$ ) $\delta$ 7.05-7.14 (m, 8H), 6.88 (s. br., 3H), 6.66 (s. br., 5H), 3.23 (s. br., $\left.4 \mathrm{H}, \mathrm{CH}\left(\mathrm{CH}_{3}\right)_{2}\right), 1.85$ (s, br., $\left.4 \mathrm{H}, \mathrm{CH}_{2} \mathrm{Ph}\right), 1.66$ (s, $\left.6 \mathrm{H}, \mathrm{CH}_{3}\right), 1.18\left(\mathrm{~d},{ }^{3} J_{\mathrm{H}-\mathrm{H}}=6.6 \mathrm{~Hz}\right.$, $\left.24 \mathrm{H}, \mathrm{CH}\left(\mathrm{CH}_{3}\right)_{2}\right)$.

${ }^{13} \mathrm{C}\left\{{ }^{1} \mathrm{H}\right\}$ NMR (toluene- $d_{8}, 75 \mathrm{MHz}, \underline{80{ }^{\circ} \mathrm{C}}$ ) $\delta 145.12$ (quat.), 144.47 (quat.), 130.22 (br., $\mathrm{CH}$ ), 126.89 (br., $\mathrm{CH}$ ), 125. $95(\mathrm{CH}), 124.01(\mathrm{CH}), 123.30(\mathrm{CH}), 110.17$ (quat.), 70.97 (br. $\mathrm{CH}_{2} \mathrm{Ph}$ ), 28.73 (br. $\left.\left(\mathrm{CH}\left(\mathrm{CH}_{3}\right)_{2}\right)\right), 25.28\left(\mathrm{CH}\left(\mathrm{CH}_{3}\right)_{2}\right), 24.98\left(\mathrm{CH}\left(\mathrm{CH}_{3}\right)_{2}\right), 16.17\left(\mathrm{CH}_{3}\right)$.

Peak assignments were facilitated by HSQC, COSY and NOESY spectra.

Anal. Calcd for $\mathrm{C}_{42} \mathrm{H}_{54} \mathrm{HfN}_{2}$ : C, 65.91; H, 7.11; N, 3.66. Found: C, 65.99; H, 7.14; N, 3.58. 
Figure 3. ${ }^{1} \mathrm{H}$ NMR and APT spectra of 7 acquired at $-30{ }^{\circ} \mathrm{C}$.

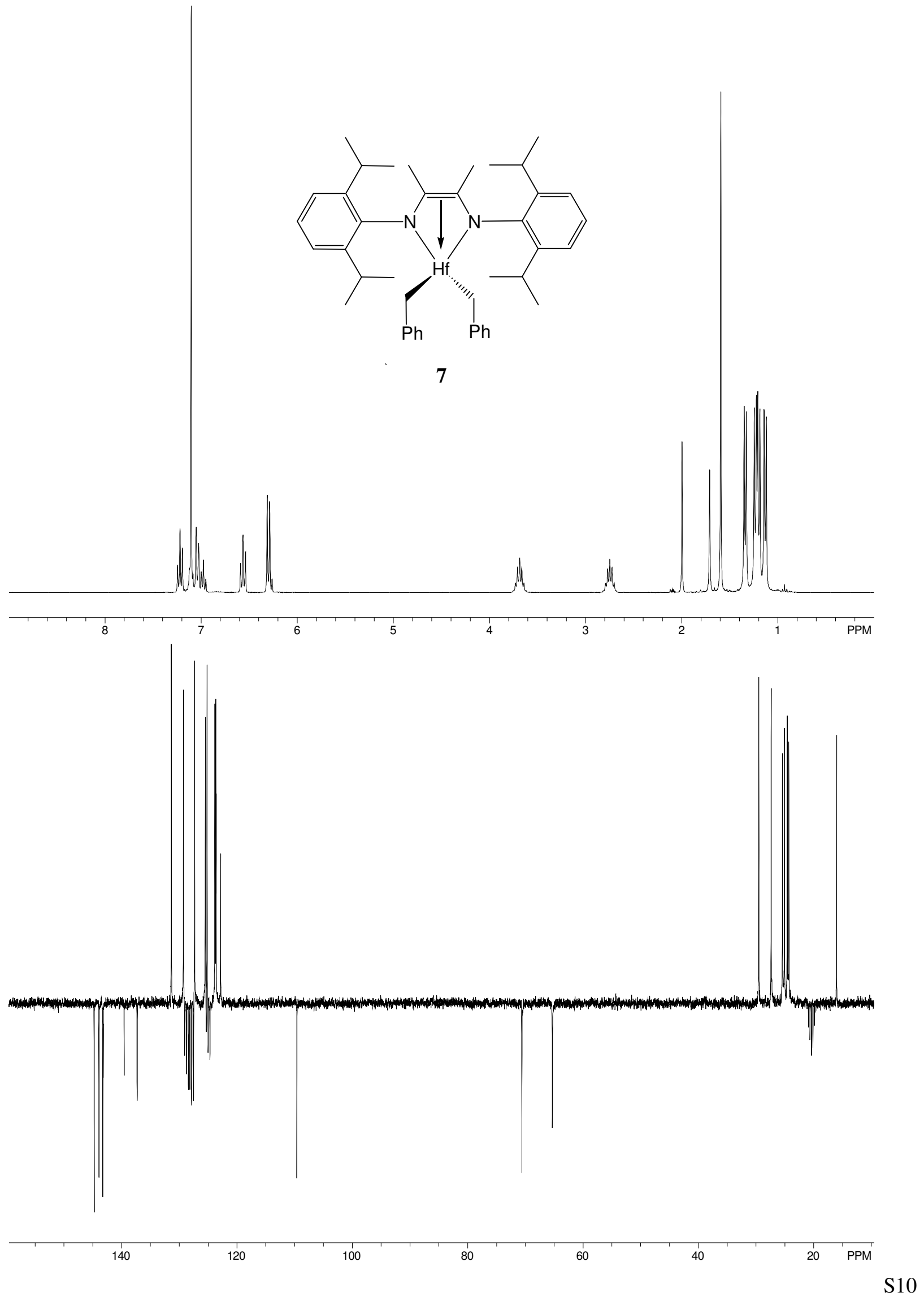


Figure $4 .{ }^{1} \mathrm{H}$ NMR and APT spectra of $\mathbf{7}$ acquired at $23{ }^{\circ} \mathrm{C}$.

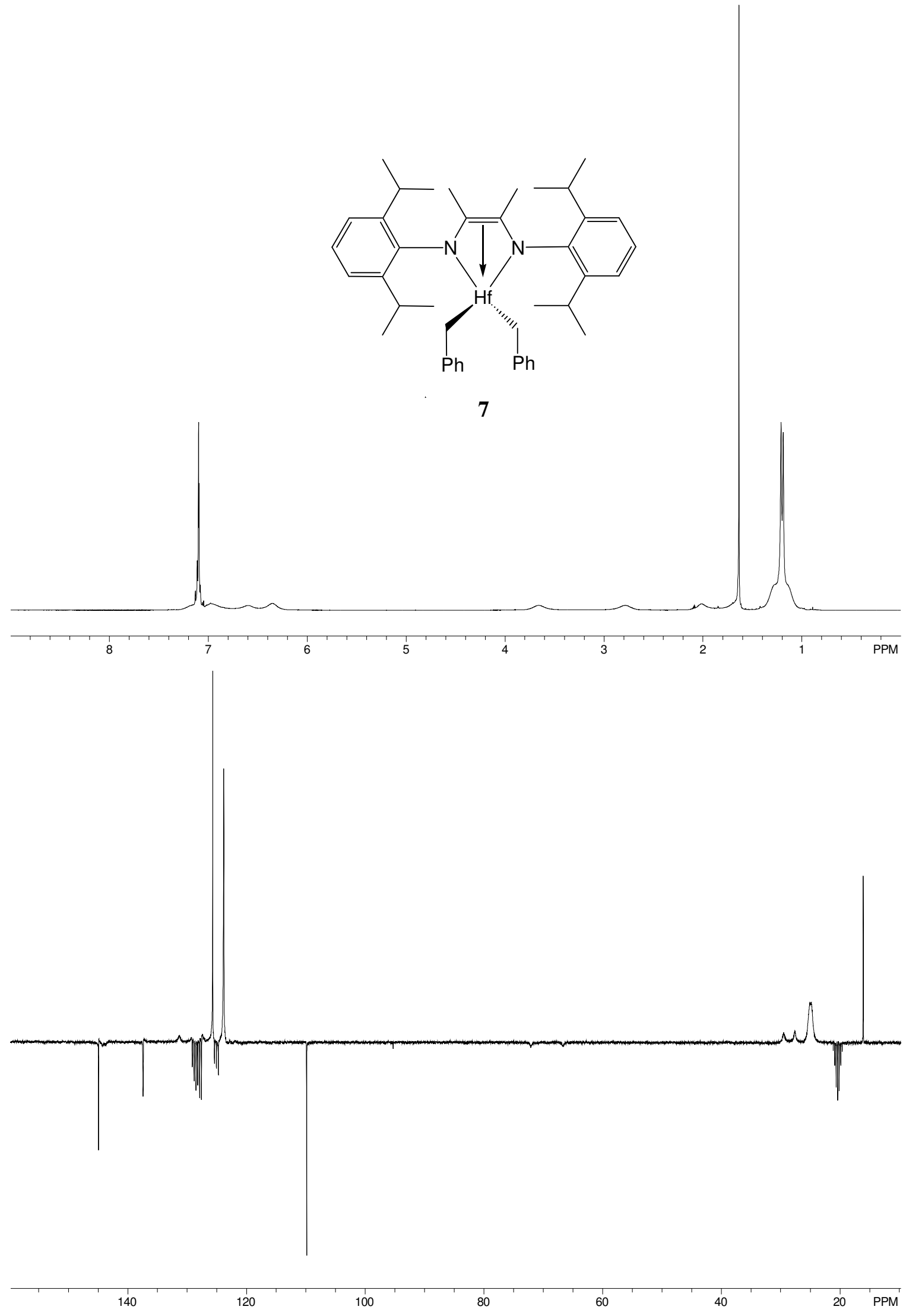


Figure 5. ${ }^{1} \mathrm{H}$ NMR and APT spectra of 7 acquired at $80{ }^{\circ} \mathrm{C}$.

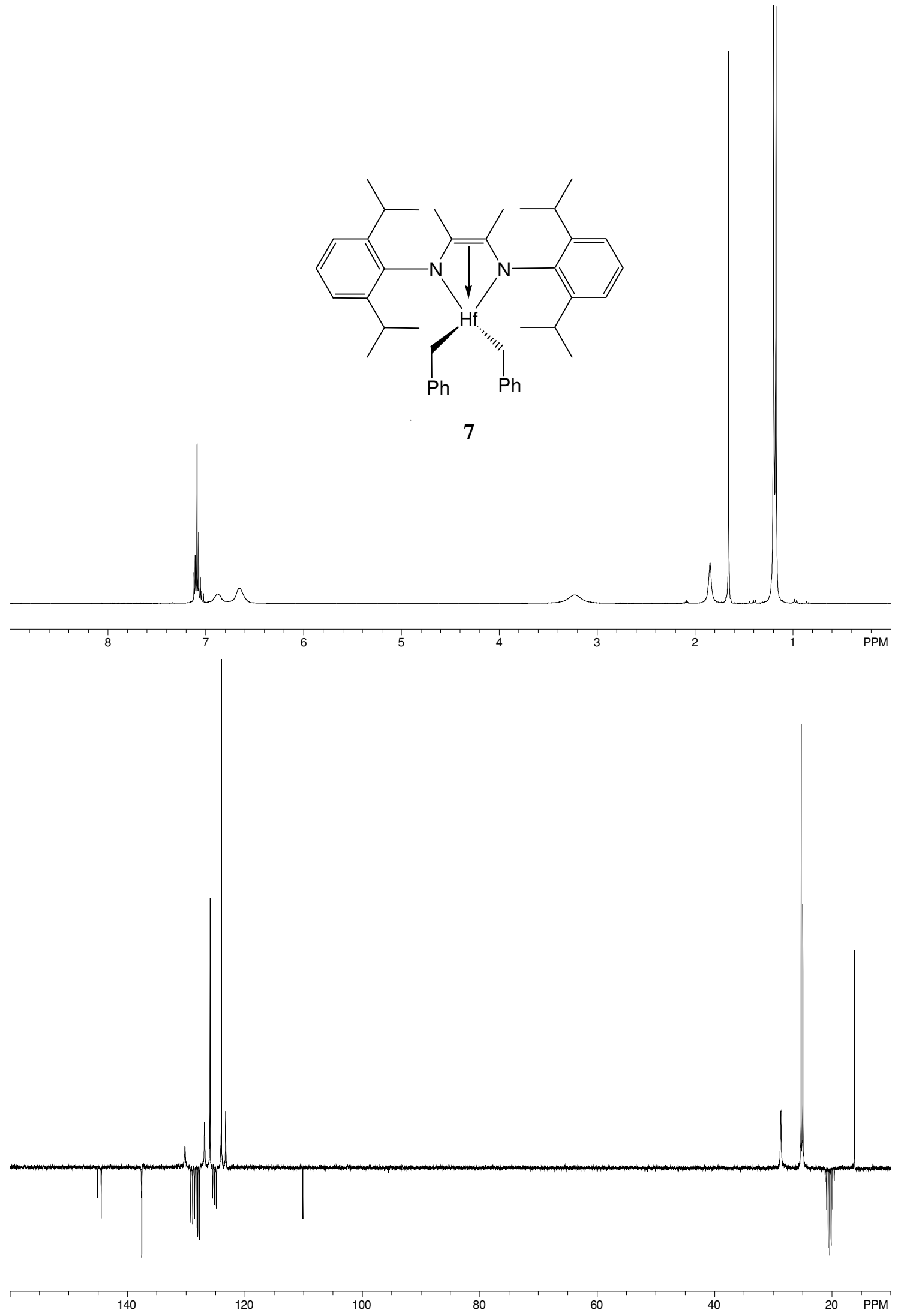


Figure 6. ${ }^{1} \mathrm{H}$ NMR VT spectra of 7. Temperature range between $35-85{ }^{\circ} \mathrm{C}, 10 \mathrm{deg}$ difference between each spectrum.

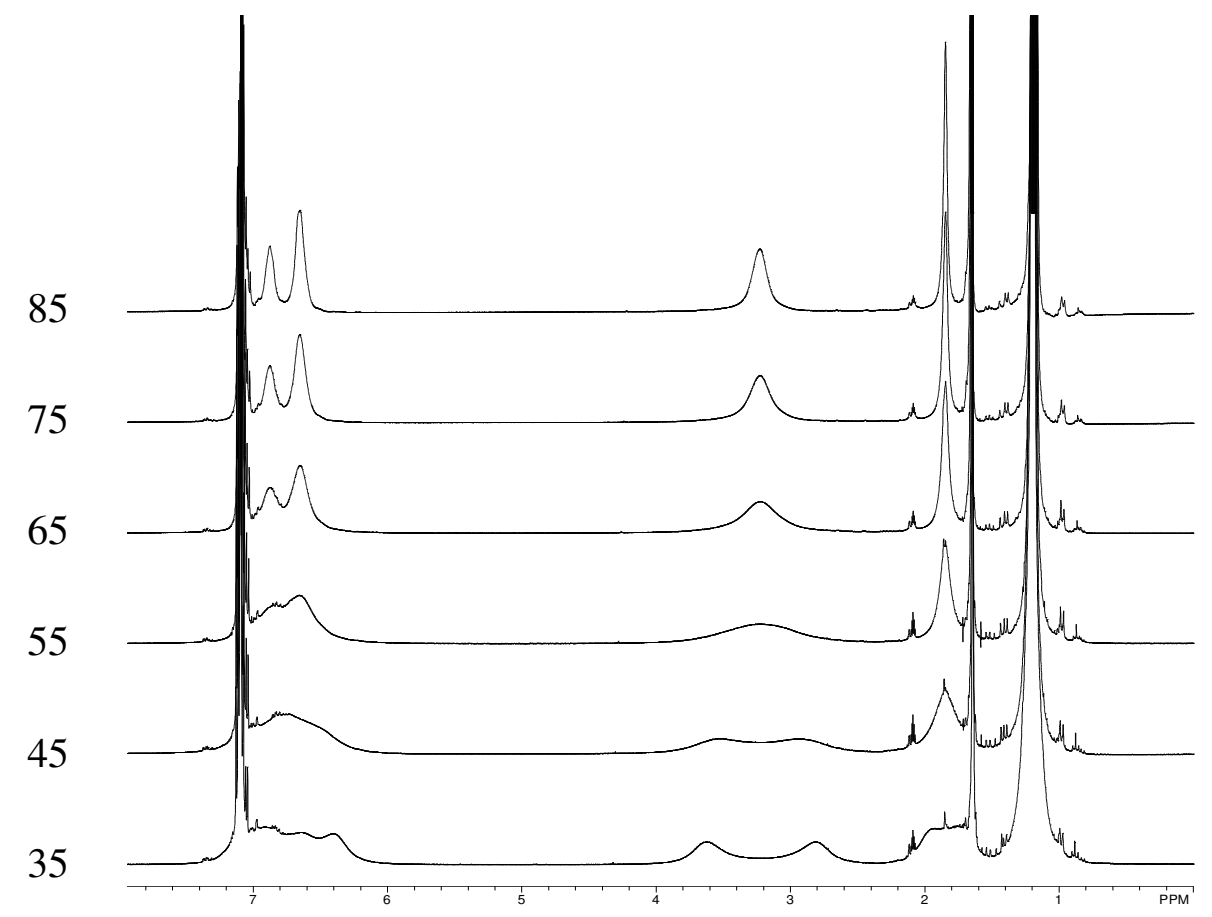

Figure 7. Fragment of ${ }^{1} \mathrm{H}$ NMR VT spectra of 7. Temperature range between $49-57{ }^{\circ} \mathrm{C}, 1 \mathrm{deg}$ difference between each spectrum.

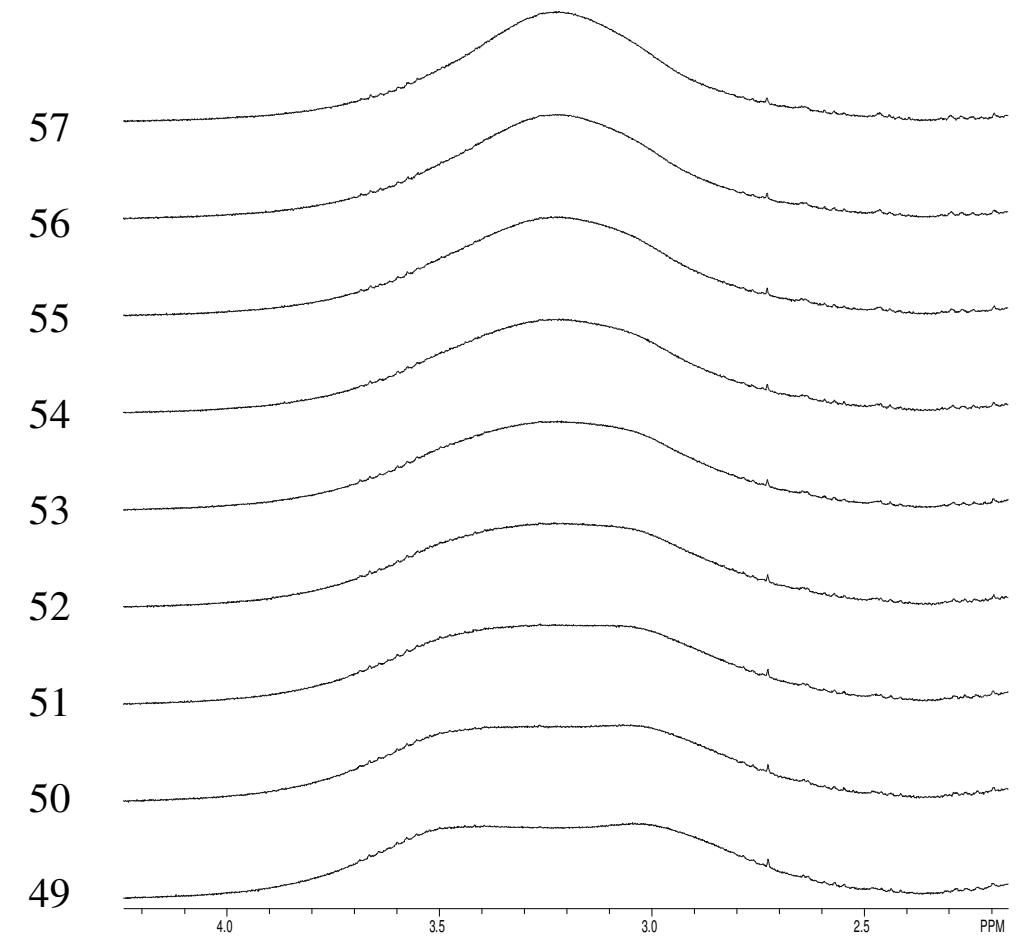


Free enthalpy of activation was determined using the following formula: $\Delta \mathrm{G}^{\ddagger}=-\mathrm{RT}[\ln (\mathrm{kc} / \mathrm{Tc})+$ $\ln (\mathrm{h} / \kappa)]$ where:

$\mathrm{kc}($ rate constant at coalescence $)=\pi(\Delta v) / 1.414213$

$\Delta v$ - difference between coalescing peaks at low exchange regime (in $\mathrm{Hz}$ )

$\mathrm{R}$ (universal gas constant $)=0.001987 \mathrm{kcal} / \mathrm{mol}^{* \mathrm{~K}}$

$\kappa($ Boltzmann constant $)=1.38 * 10^{-16} \mathrm{erg} / \mathrm{K}$

$\mathrm{h}($ Planck constant $)=6.63 * 10^{-27} \mathrm{erg} * \mathrm{sec}$

Tc (temperature at coalescence) (in Kelvins)

Free enthalpy of activation can be also calculated using the following formula:

$\Delta \mathrm{G}^{\ddagger}=0.00458 * \mathrm{Tc}[10.32+\log (\mathrm{Tc} / \mathrm{kc})]$. The results will be given in $\mathrm{kcal} / \mathrm{mol}^{-1}$

Coalescence temperature of isopropyl methine protons is $51.5^{\circ} \mathrm{C}\left(\mathrm{k}=625.3 \mathrm{~s}^{-1}\right)$

Difference between coalescing peaks at low exchange regime $(\Delta v)=281.5 \mathrm{~Hz}$

$\Delta \mathrm{G}^{\ddagger}=14.9 \mathrm{kcal} / \mathrm{mol}^{-1}$ 


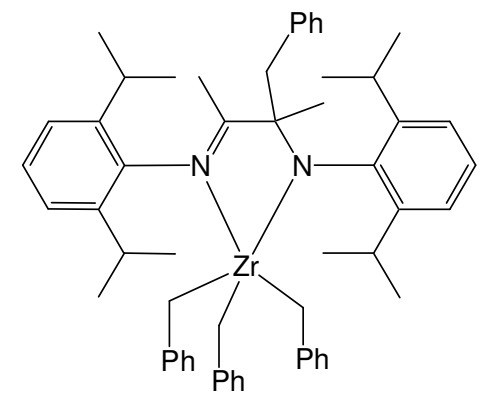

6 $\underset{2 \text { days }}{\stackrel{6{ }^{\circ} \mathrm{C}}{\longrightarrow}}$

Preparation of 8. In a drybox, a vial containing $0.748 \mathrm{~g}(1.85 \mathrm{mmol})$ of N,N'-bis(2,6diisopropylphenyl)-2,3-butanediimine and $1.011 \mathrm{~g}(2.22 \mathrm{mmol})$ of $\mathrm{Zr}\left(\mathrm{CH}_{2} \mathrm{Ph}\right)_{4}$ was charged with $9 \mathrm{~mL}$ of toluene to form a solution. The vial was taken out of the drybox and it was wrapped with aluminum foil and then heated for $4 \mathrm{~d}$ at $70{ }^{\circ} \mathrm{C}$ to yield a dark solution. The solvent was removed under reduced pressure to give a dark crystalline residue. Hexanes were added (50 mL) and mixture was heated to reflux. The solution was filtered while hot and the resulting filtrate was cooled and concentrated by removing $20 \mathrm{~mL}$ of solvent. The resulting solution was stored at $-30{ }^{\circ} \mathrm{C}$ overnight leading to the formation of a yellow crystalline material. The mother liquor was decanted and crystalline solid was washed with cold hexanes $(2 \times 10 \mathrm{~mL})$ and dried under reduced pressure to give pure product, $0.450 \mathrm{~g} \mathrm{(36 \% ).}$

${ }^{1} \mathrm{H}$ NMR (toluene- $\left.d_{8}, 300 \mathrm{MHz}, 23{ }^{\circ} \mathrm{C}\right) \delta 7.04-7.2(\mathrm{~m}, 8 \mathrm{H}), 6.93(\mathrm{~m}, 3 \mathrm{H}), 6.58\left(\mathrm{t},{ }^{3} J_{\mathrm{H}-\mathrm{H}}=7.8 \mathrm{~Hz}\right.$, meta- $\left.\mathrm{CH}_{2} \mathrm{Ph}\right), 6.18\left(\mathrm{t},{ }^{3} J_{\mathrm{H}-\mathrm{H}}=7.5 \mathrm{~Hz}\right.$, para- $\left.\mathrm{CH}_{2} \mathrm{Ph}\right), 6.14\left(\mathrm{t},{ }^{3} \mathrm{~J}_{\mathrm{H}-\mathrm{H}}=7.5 \mathrm{~Hz}\right.$, ortho- $\left.\mathrm{CH}_{2} \mathrm{Ph}\right), 3.52$ (septet, $\left.2 \mathrm{H},{ }^{3} J_{\mathrm{H}-\mathrm{H}}=6.9 \mathrm{~Hz}, \mathrm{CH}\left(\mathrm{CH}_{3}\right)_{2}\right), 2.71$ (septet $\left.2 \mathrm{H},{ }^{3} J_{\mathrm{H}-\mathrm{H}}=6.9 \mathrm{~Hz}, \mathrm{CH}\left(\mathrm{CH}_{3}\right)_{2}\right), 2.04(\mathrm{~s}, 2 \mathrm{H}$, $\left.\mathrm{CH}_{2} \mathrm{Ph}\right), 1.84\left(\mathrm{~s}, 2 \mathrm{H}, \mathrm{CH}_{2} \mathrm{Ph}\right), 1.65\left(\mathrm{~s}, 6 \mathrm{H}, \mathrm{CH}_{3}\right), 1.33\left(\mathrm{~d},{ }^{3} \mathrm{~J}_{\mathrm{H}-\mathrm{H}}=6.9 \mathrm{~Hz}, 6 \mathrm{H}, \mathrm{CH}\left(\mathrm{CH}_{3}\right)_{2}\right), 1.21(\mathrm{~d}$, $\left.{ }^{3} J_{\mathrm{H}-\mathrm{H}}=6.6 \mathrm{~Hz}, 6 \mathrm{H}, \mathrm{CH}\left(\mathrm{CH}_{3}\right)_{2}\right), 1.19\left(\mathrm{~d},{ }^{3} J_{\mathrm{H}-\mathrm{H}}=6.6 \mathrm{~Hz}, 6 \mathrm{H}, \mathrm{CH}\left(\mathrm{CH}_{3}\right)_{2}\right), 1.12\left(\mathrm{~d},{ }^{3} J_{\mathrm{H}-\mathrm{H}}=6.6 \mathrm{~Hz}\right.$, $\left.6 \mathrm{H}, \mathrm{CH}\left(\mathrm{CH}_{3}\right)_{2}\right)$.

${ }^{13} \mathrm{C}\left\{{ }^{1} \mathrm{H}\right\}$ NMR (toluene- $\left.d_{8}, 75 \mathrm{MHz}, 23{ }^{\circ} \mathrm{C}\right) \delta 145.29$ (quat.), 143.98 (quat.), 143.46 (quat.), 141.81 (quat.), $132.37(\mathrm{CH}), 130.39(\mathrm{CH}), 127.13(\mathrm{CH}), 125.60(\mathrm{CH}), 123.89(\mathrm{CH}), 123.80$ $(C H), 123.42(C H), 123.32(C H), 122.45(C H), 110.02$ (quat.), $60.45\left(C_{2} \mathrm{Ph},{ }^{1} J_{\mathrm{CH}}=137.9 \mathrm{~Hz}\right)$, $57.63\left(\mathrm{CH}_{2} \mathrm{Ph},{ }^{1} J_{\mathrm{CH}}=129.4 \mathrm{~Hz}\right), 29.40\left(\mathrm{CH}\left(\mathrm{CH}_{3}\right)_{2}\right), 27.70\left(\mathrm{CH}\left(\mathrm{CH}_{3}\right)_{2}\right), 25.41\left(\mathrm{CH}\left(\mathrm{CH}_{3}\right)_{2}\right), 25.13$ $\left(\mathrm{CH}\left(\mathrm{CH}_{3}\right)_{2}\right), 24.85\left(\mathrm{CH}\left(\mathrm{CH}_{3}\right)_{2}\right), 24.46\left(\mathrm{CH}\left(\mathrm{CH}_{3}\right)_{2}\right), 16.90\left(\mathrm{CH}_{3}\right)$.

Anal. Calcd for $\mathrm{C}_{42} \mathrm{H}_{54} \mathrm{ZrN}_{2}$ : C, 74.28; H, 8.16; N, 4.12. Found: C, 74.13; H, 8.60; N, 4.11. 
Figure $8 .{ }^{1} \mathrm{H}$ and APT spectra of $\mathbf{8}$.
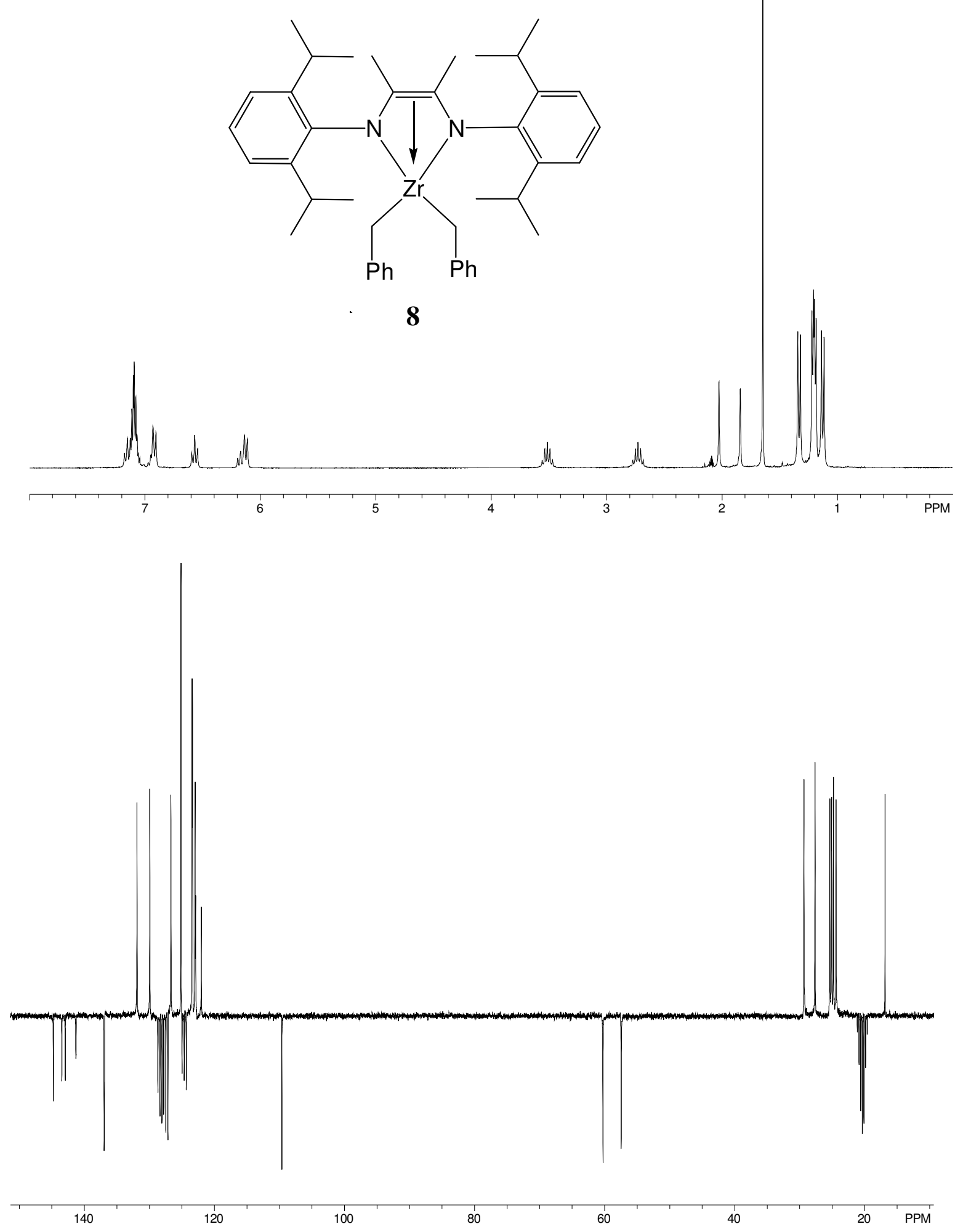
Figure 9. Fragment of ${ }^{1} \mathrm{H}$ NMR VT spectra of 8 . Temperature range between $40-90{ }^{\circ} \mathrm{C}, 10 \mathrm{deg}$ difference between each spectrum.

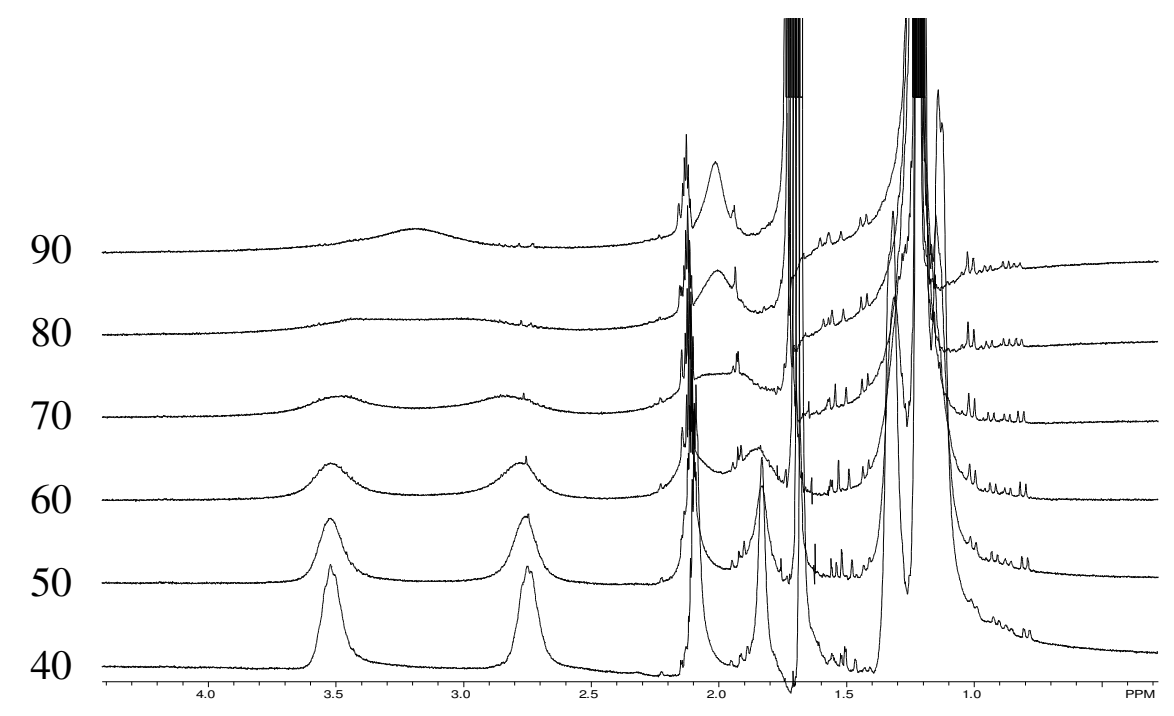

Coalescence temperature of benzyl methylene protons $(1.837 \mathrm{ppm}$ and 2.038$)$ is $71{ }^{\circ} \mathrm{C}$ $\left(\mathrm{k}=134 \mathrm{~s}^{-1}\right)$. Difference between coalescing peaks at low exchange regime $(\Delta v)=60.25 \mathrm{~Hz}$ $\Delta \mathrm{G}^{\ddagger}=16.9 \mathrm{kcal} / \mathrm{mol}^{-1}$

Figure 10. Fragment of ${ }^{1} \mathrm{H}$ NMR VT spectra of 8 . Temperature range between $68-75{ }^{\circ} \mathrm{C}, 1 \mathrm{deg}$ difference between each spectrum.

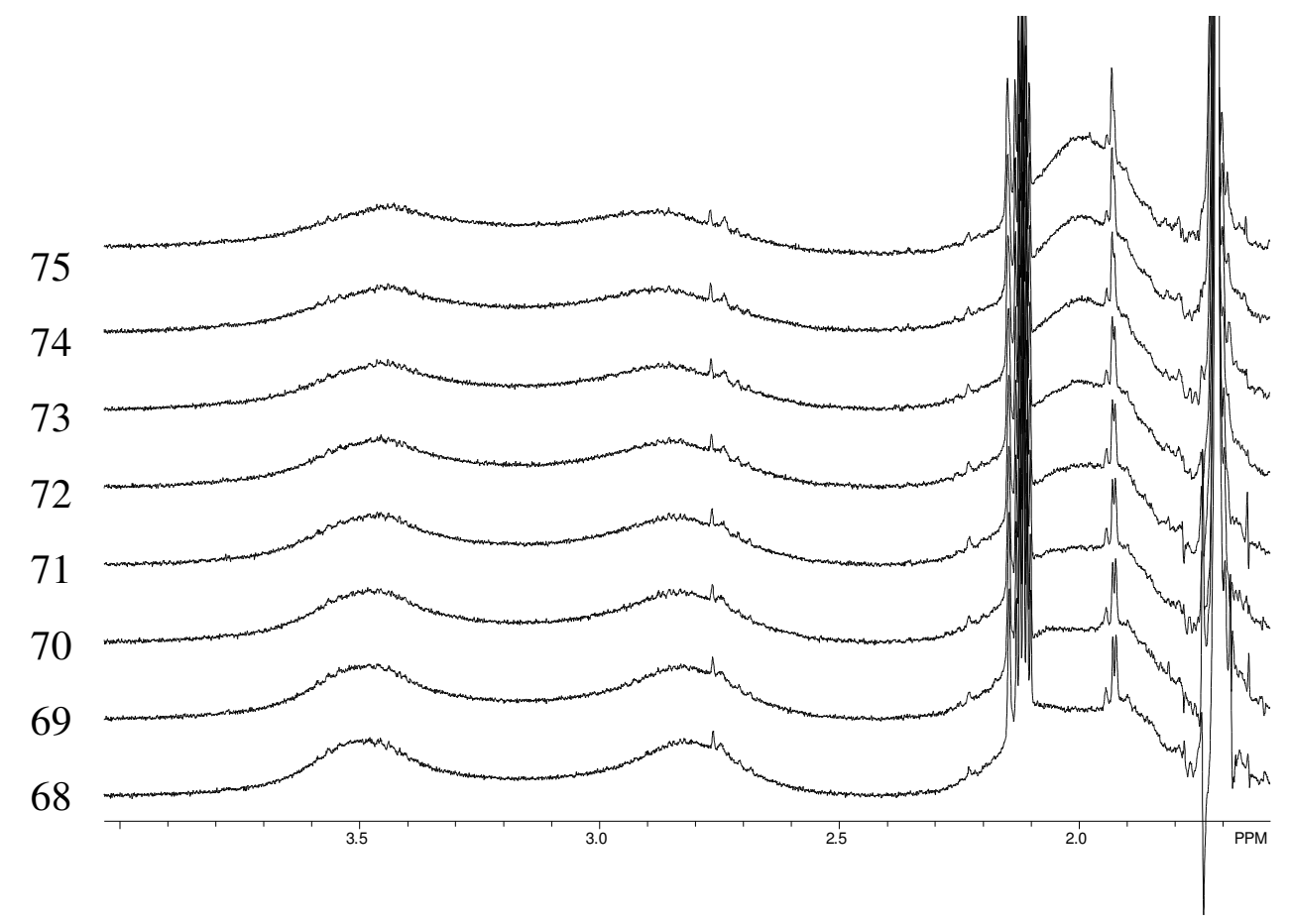


Figure 11. ${ }^{1} \mathrm{H}$ NMR spectra of the reaction mixture between diimine $9(36 \mathrm{mg})$ and $\mathrm{Hf}\left(\mathrm{CH}_{2} \mathrm{Ph}\right)_{4}$ $(51.9 \mathrm{mg})$ in $0.6 \mathrm{~mL}$ of toluene- $\mathrm{d}_{8}-5 \mathrm{~min}$. Colored arrows correspond to resonances from compounds 10 (blue), 12 (red) and 14 (magenta), respectively.

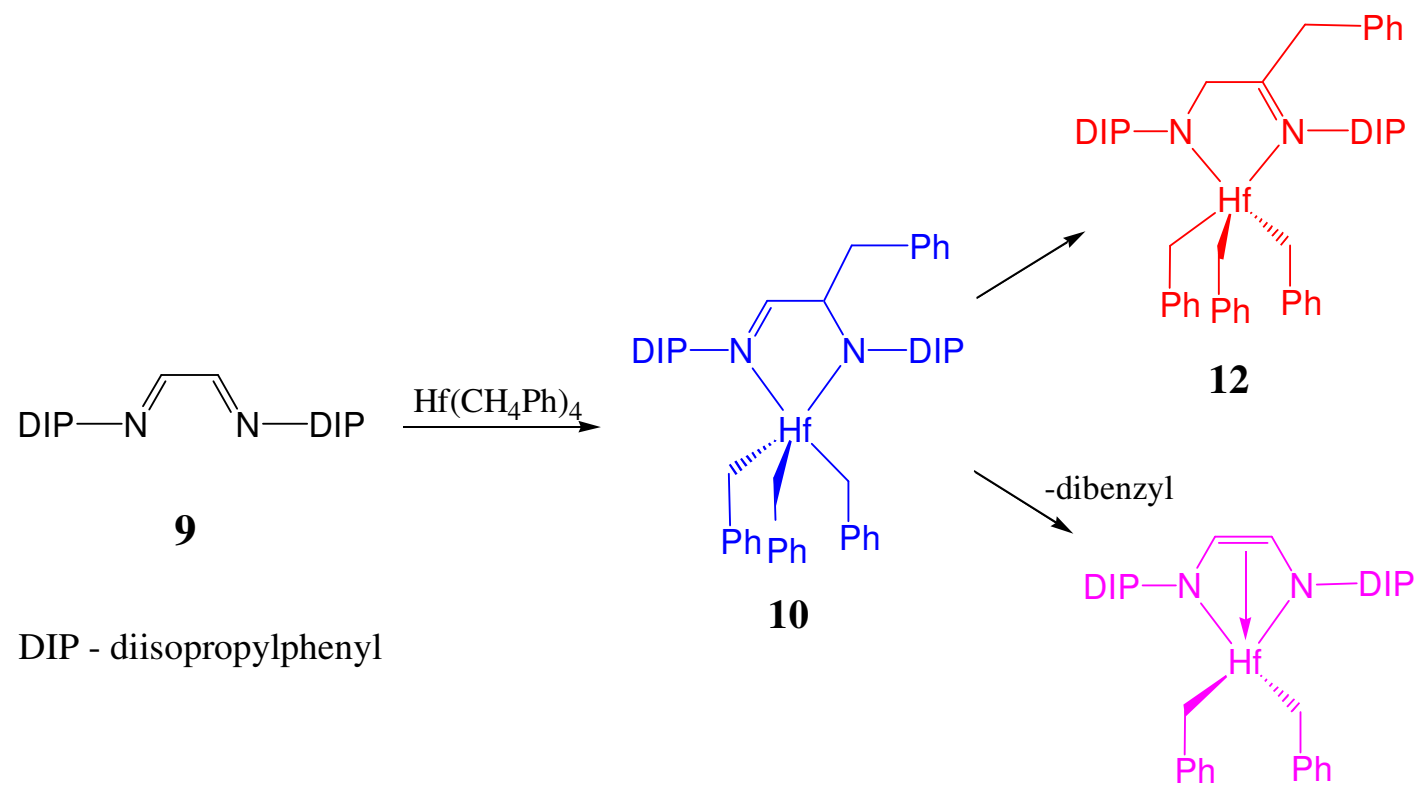

14

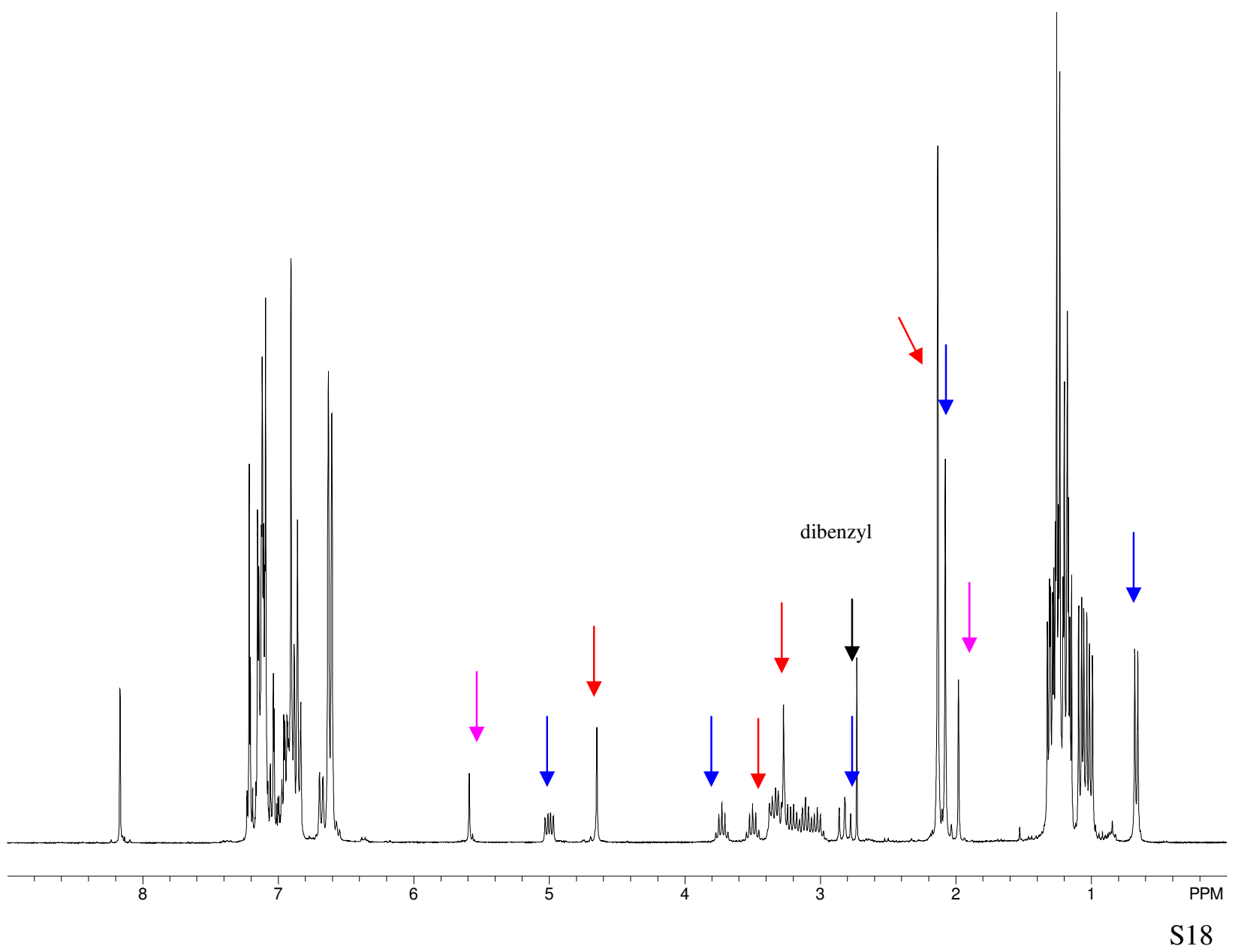


Figure 12. NMR spectra of the reaction mixture between diimine $9(36 \mathrm{mg})$ and $\mathrm{Hf}\left(\mathrm{CH}_{2} \mathrm{Ph}\right)_{4}$ $(51.9 \mathrm{mg})$ in $0.6 \mathrm{~mL}$ of toluene- $d_{8}-2.5 \mathrm{~h}$.

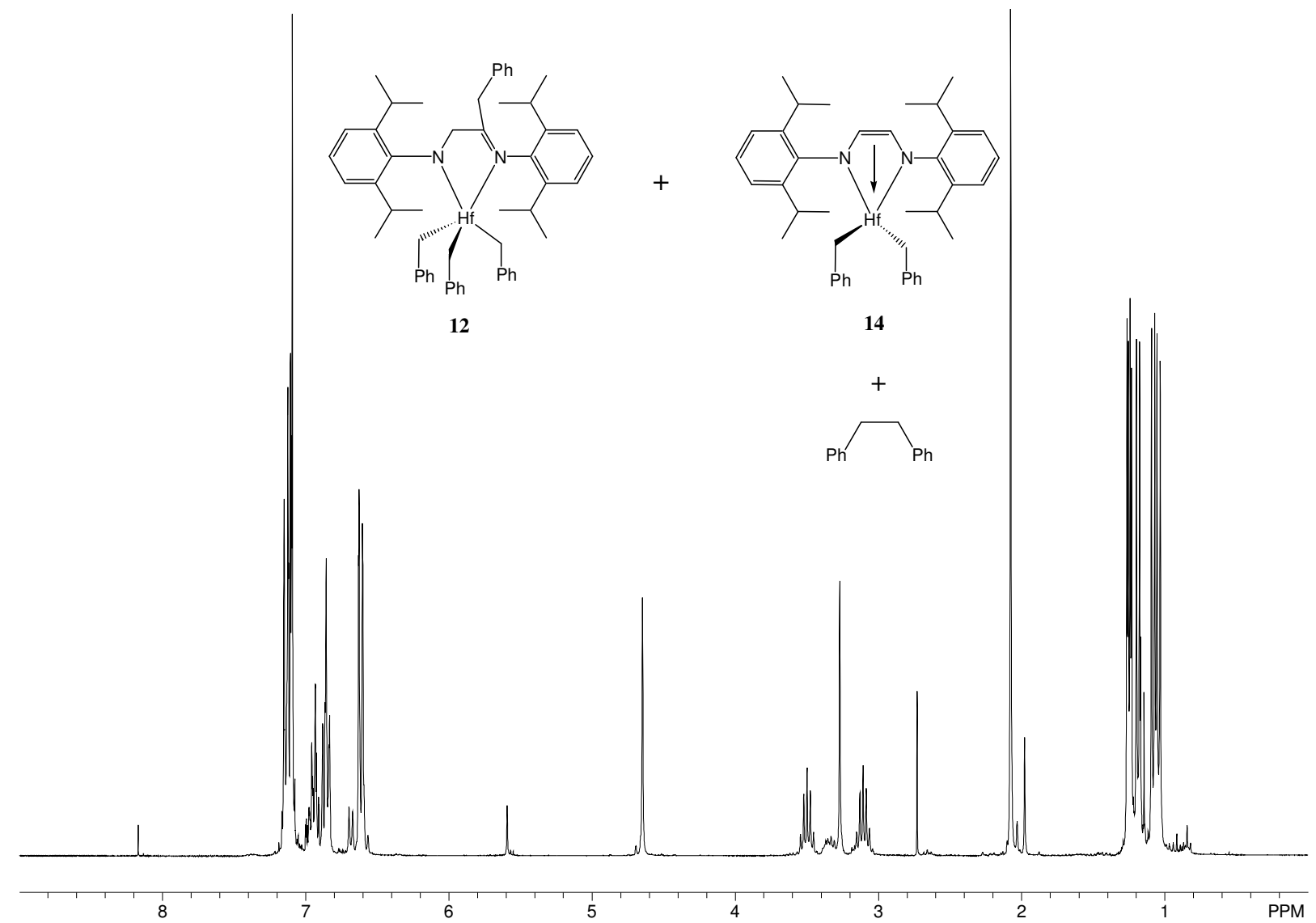

Synthesis of 12. A solution of N,N'-bis(2,6-diisopropylpenyl)-1,2-ethaneimine (0.250 g, 0.663 mmol) in toluene $(5 \mathrm{~mL})$ was treated with a solution of $\mathrm{Hf}\left(\mathrm{CH}_{2} \mathrm{Ph}\right)_{4}(0.360 \mathrm{~g}, 0.663 \mathrm{mmol})$ in toluene $(5 \mathrm{~mL})$ to form a yellow solution. This solution was stirred at ambient temperature for 20 h. Then, the volatile components were removed under reduced pressure to yield a pale yellow solid. This solid was dissolved in $6 \mathrm{~mL}$ of warm toluene and $4 \mathrm{~mL}$ of hexanes was added. Storage of this solution at $-40{ }^{\circ} \mathrm{C}$ overnight led to the deposition of pale yellow microcrystalline solid. Multiple crops were collected to yield the desired product as a yellow solid, $0.385 \mathrm{~g}$ (63\%). ${ }^{1} \mathrm{H}$ NMR $\left(\mathrm{C}_{6} \mathrm{D}_{6}, 300 \mathrm{MHz}\right): \delta 7.15-7.10(\mathrm{~m}, 12 \mathrm{H}), 6.97-6.84(\mathrm{~m}, 8 \mathrm{H}), 6.64-6.61(\mathrm{~m}, 6 \mathrm{H})$, 4.66 (s, 2H), 3.50 (septet, $J=6.9 \mathrm{~Hz}, 2 \mathrm{H}), 3.27$ (s, 2H), 3.11 (septet, $J=6.9 \mathrm{~Hz}, 2 \mathrm{H}), 2.09$ (s, $6 \mathrm{H}), 1.26(\mathrm{~d}, J=6.9 \mathrm{~Hz}, 6 \mathrm{H}), 1.19(\mathrm{~d}, J=6.9 \mathrm{~Hz}, 6 \mathrm{H}), 1.08(\mathrm{~d}, J=6.9 \mathrm{~Hz}, 6 \mathrm{H}), 1.05(\mathrm{~d}, J=6.9$ $\mathrm{Hz}, 6 \mathrm{H}) .{ }^{13} \mathrm{C}\left\{{ }^{1} \mathrm{H}\right\}$ NMR $\left(\mathrm{C}_{6} \mathrm{D}_{6}, 75 \mathrm{MHz}\right)$ : d 191.0, 150.4, 146.2, 145.4, 142.9, 140.1, 134.5, $129.4,129.1$, 128.8, 127.9, 127.8, 127.7, 126.2, 125.5, 124.7, 122.2, 86.1, 70.2, 41.6, 28.8, 28.7, 
27.2, 26.3, 24.8, 24.4. Anal Calcd. for $\mathrm{C}_{54} \mathrm{H}_{64} \mathrm{HfN}_{2}$ : C, 70.53; H, 7.01; N, 3.05. Found: C, 70.67; H, 7.26; N, 2.97.

Figure 13. ${ }^{1} \mathrm{H}$ and APT spectra of 12 (in $\mathrm{C}_{6} \mathrm{D}_{6}$ ).
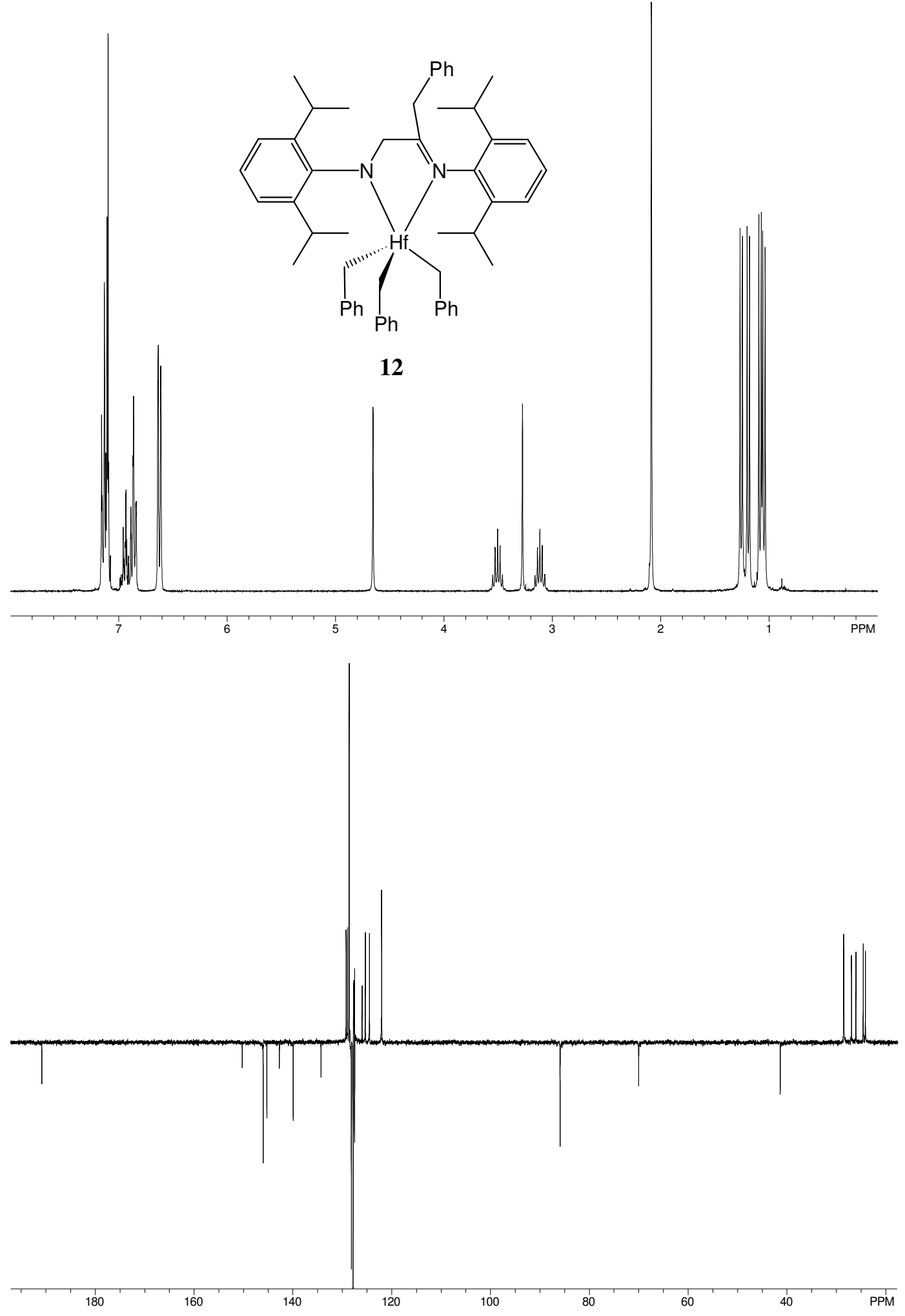

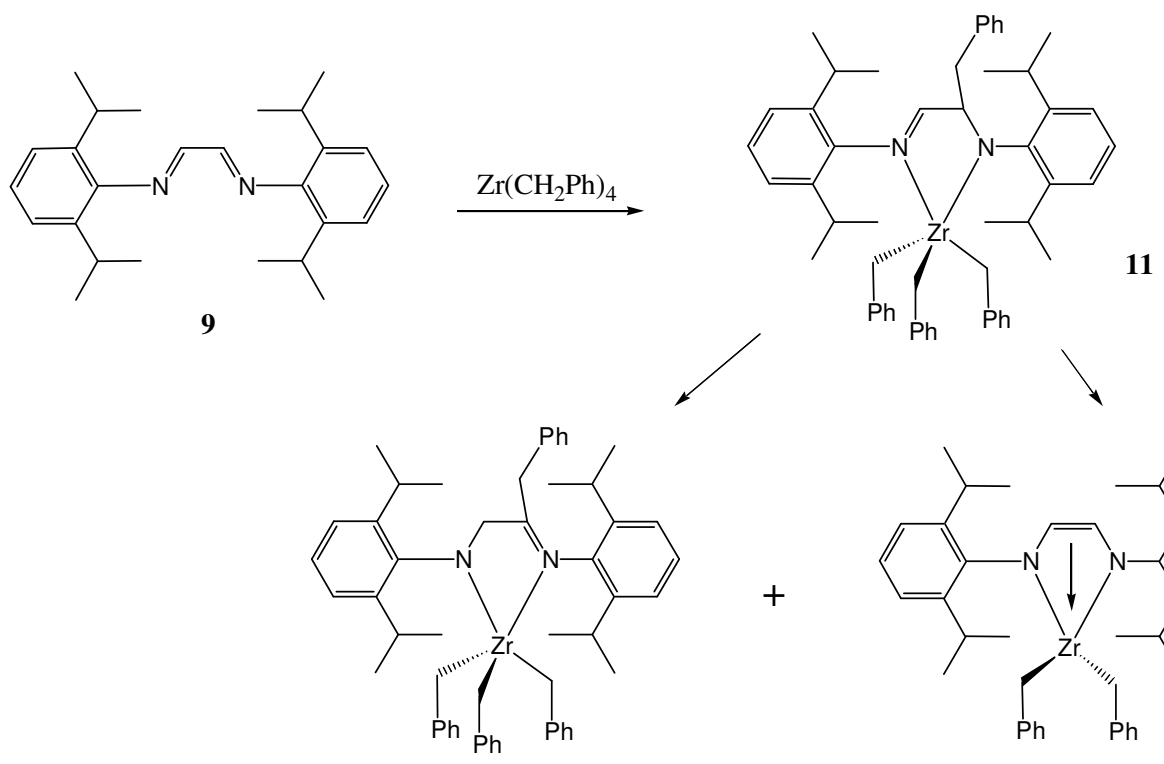

13

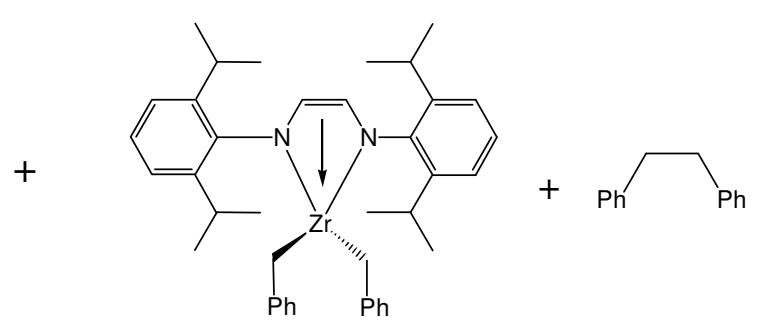

15

Synthesis of 13 and 15. A flask was charged with $0.474 \mathrm{~g}(1.26 \mathrm{mmol})$ of 1,4-bis(2,6diisopropylphenyl)-1,4-diaza-1,3-butadiene, $0.574 \mathrm{~g}(1.26 \mathrm{mmol})$ of $\mathrm{Zr}\left(\mathrm{CH}_{2} \mathrm{Ph}\right)_{4}$ and $35 \mathrm{~mL}$ of toluene. The resulting yellow solution was stirred overnight at ambient temperature. The solvent was removed under reduced pressure. The resulting residue was treated with $30 \mathrm{~mL}$ of hexanes and the yellow suspension was stirred for $2 \mathrm{~h}$. The mixture was filtered through glass frit, and the remaining yellow solid was washed with hexanes $(2 \times 15 \mathrm{~mL})$ and then dried under reduced pressure to give $302 \mathrm{mg}$ of product (13). Yield 29\%. The product can be easily recrystallized if needed from THF/hexane solvent mixture. Hexanes were removed under reduced pressure from combined hexanes fractions leaving $0.54 \mathrm{~g}$ of yellow oil $(\mathbf{1 5}+$ dibenzyl $)$. Yield $52 \%$.

Analytical data for $13 .{ }^{1} \mathrm{H}\left(\mathrm{CDCl}_{3}, 300 \mathrm{~Hz}, 23{ }^{\circ} \mathrm{C}\right) \delta 7.31(\mathrm{~m}, 6 \mathrm{H}), 7.15\left(\mathrm{~m}, 5 \mathrm{H}, \mathrm{CH}_{2} \mathrm{C}_{6} H_{5}\right)$, $7.03\left(\mathrm{~d}, 6 \mathrm{H},{ }^{3} J_{\mathrm{H}-\mathrm{H}}=7.5 \mathrm{~Hz}\right.$, meta-Hf-CH $\left.\mathrm{CH}_{2} \mathrm{Ph}\right), 6.86\left(\mathrm{t}, 3 \mathrm{H},{ }^{3} J_{\mathrm{H}-\mathrm{H}}=7.2 \mathrm{~Hz}\right.$, para-Hf-CH $\left.\mathrm{H}_{2} \mathrm{Ph}\right), 6.32$ $\left(\mathrm{d}, 6 \mathrm{H},{ }^{3} \mathrm{~J}_{\mathrm{H}-\mathrm{H}}=7.5 \mathrm{~Hz}\right.$, ortho-Hf-CH $\left.\mathrm{CH}_{2} \mathrm{Ph}\right), 4.55$ (s, 2H), $3.61(\mathrm{~s}, 2 \mathrm{H}), 3.49$ (septet, $2 \mathrm{H},{ }^{3} J_{\mathrm{H}-\mathrm{H}}=6.9$ $\left.\mathrm{Hz}, \mathrm{CH}\left(\mathrm{CH}_{3}\right)_{2}\right), 2.94$ (septet, $\left.2 \mathrm{H},{ }^{3} J_{\mathrm{H}-\mathrm{H}}=6.9 \mathrm{~Hz}, \mathrm{CH}\left(\mathrm{CH}_{3}\right)_{2}\right), 1.89$ (s, 6H, Hf-CH $\left.\mathrm{C}_{6} \mathrm{H}_{5}\right), 1.32$ (d, $\left.6 \mathrm{H},{ }^{3} J_{\mathrm{H}-\mathrm{H}}=6.6 \mathrm{~Hz}, \mathrm{CH}\left(\mathrm{CH}_{3}\right)_{2}\right), 1.27\left(\mathrm{~d}, 6 \mathrm{H},{ }^{3} J_{\mathrm{H}-\mathrm{H}}=6.6 \mathrm{~Hz}, \mathrm{CH}\left(\mathrm{CH}_{3}\right)_{2}\right), 1.17\left(\mathrm{~d}, 6 \mathrm{H},{ }^{3} J_{\mathrm{H}-\mathrm{H}}=6.9\right.$ $\left.\mathrm{Hz}, \mathrm{CH}\left(\mathrm{CH}_{3}\right)_{2}\right), 1.04\left(\mathrm{~d}, 6 \mathrm{H},{ }^{3} J_{\mathrm{H}-\mathrm{H}}=6.9 \mathrm{~Hz}, \mathrm{CH}\left(\mathrm{CH}_{3}\right)_{2}\right) .{ }^{13} \mathrm{C}\left\{{ }^{1} \mathrm{H}\right\}\left(\mathrm{CDCl}_{3}, 75 \mathrm{~Hz}, 23{ }^{\circ} \mathrm{C}\right) \delta$ 190.93 ( $\mathrm{N}=C$ ), 149.33 (quat.), 145.45 (quat.), 145.06 (quat.), 143.25 (quat.), 139.32 (quat.), 134.14 (quat.), $129.23(\mathrm{CH}), 128.94(\mathrm{CH}), 128.58(\mathrm{CH}), 127.71(\mathrm{CH}), 127.33(\mathrm{CH}), 127.03$ $(C H), 125.66(C H), 124.97(C H), 124.06(C H), 121.68(C H), 75.97\left(\mathrm{Hf}_{-} C_{H_{2}} \mathrm{C}_{6} \mathrm{H}_{5},{ }^{1} J_{\mathrm{CH}}=122.7\right.$ 
$\mathrm{Hz}), 69.61\left({ }^{1} J_{\mathrm{CH}}=134.3 \mathrm{~Hz}\right), 41.62\left({ }^{1} J_{\mathrm{CH}}=127.9 \mathrm{~Hz}\right), 28.62\left(\mathrm{CH}\left(\mathrm{CH}_{3}\right)_{2}\right), 28.16\left(\mathrm{CH}\left(\mathrm{CH}_{3}\right)_{2}\right)$, $27.28\left(\mathrm{CH}\left(\mathrm{CH}_{3}\right)_{2}\right), 25.81\left(\mathrm{CH}\left(\mathrm{CH}_{3}\right)_{2}\right), 24.59\left(\mathrm{CH}\left(\mathrm{CH}_{3}\right)_{2}\right), 23.34\left(\mathrm{CH}\left(\mathrm{CH}_{3}\right)_{2}\right)$.

Anal. Calcd for $\mathrm{C}_{54} \mathrm{H}_{64} \mathrm{~N}_{2} \mathrm{Zr}$ : C, 77.92; H, 7.75; N, 3.37. Found: C, 77.28; H, 8.31; N, 3.43.

Analytical data for $15 .{ }^{1} \mathrm{H}$ NMR (toluene-d $\left.{ }^{8}, 300 \mathrm{MHz}, 23{ }^{\circ} \mathrm{C}\right) \delta 7.10(\mathrm{~s}, 6 \mathrm{H}), 6.94-7.12(\mathrm{~m}$, $\left.10 \mathrm{H},\left(\mathrm{CH}_{2} \mathrm{Ph}\right)_{2}\right), 6.84$ (t. br., $4 \mathrm{H},{ }^{3} J_{\mathrm{H}-\mathrm{H}}=7.5 \mathrm{~Hz}$, meta- $\mathrm{CH}_{2} \mathrm{Ph}$ ), 6.52 (d. br., $2 \mathrm{H},{ }^{3} J_{\mathrm{H}-\mathrm{H}}=6.6 \mathrm{~Hz}$, para- $\mathrm{CH}_{2} \mathrm{Ph}$ ), 6.44 (s. br., $4 \mathrm{H}$, ortho- $\mathrm{CH}_{2} \mathrm{Ph}$ ), 5.52 (s, $2 \mathrm{H}, H \mathrm{C}=\mathrm{C}$ ), 3.13 (septet, $4 \mathrm{H},{ }^{3} J_{\mathrm{H}-\mathrm{H}}=6.6$ $\left.\mathrm{Hz}, \mathrm{CH}\left(\mathrm{CH}_{3}\right)_{2}\right), 2.71\left(\mathrm{~s}, 4 \mathrm{H},\left(\mathrm{CH}_{2} \mathrm{Ph}\right)_{2}\right), 2.12\left(\mathrm{~s}, 4 \mathrm{H}, \mathrm{CH}_{2} \mathrm{Ph}\right), 1.23\left(\mathrm{~d}, 24 \mathrm{H},{ }^{3} J_{\mathrm{H}-\mathrm{H}}=6.9 \mathrm{~Hz}\right.$, $\left.\mathrm{CH}\left(\mathrm{CH}_{3}\right)_{2}\right) \cdot{ }^{13} \mathrm{C}\left\{{ }^{1} \mathrm{H}\right\}$ NMR (toluene-d $\left.\mathrm{d}^{8}, 75 \mathrm{MHz}, 23{ }^{\circ} \mathrm{C}\right) \delta 147.35$ (quat.), 143.34 (quat.), 141.82 (dibenzyl), 141.16 (quat.), $131.32(\mathrm{CH}), 128.62$ (dibenzyl), 128.44 (dibenzyl), 126.05 (dibenzyl), $125.99(\mathrm{CH}), 125.71(\mathrm{CH}), 123.51(\mathrm{CH}), 123.34(\mathrm{CH}), 107.22(\mathrm{CH}), 61.81\left(\mathrm{CH}_{2} \mathrm{Ph},{ }^{1} J_{\mathrm{C}-\mathrm{H}}=134.1\right.$ $\mathrm{Hz}), 38.09$ (dibenzyl), $28.57\left(\mathrm{CH}\left(\mathrm{CH}_{3}\right)_{2}\right), 25.04\left(\mathrm{CH}\left(\mathrm{CH}_{3}\right)_{2}\right)$. 
Figure 14. ${ }^{1} \mathrm{H}$ NMR spectrum of the reaction mixture between diimine $9(53 \mathrm{mg})$ and $\mathrm{Zr}\left(\mathrm{CH}_{2} \mathrm{Ph}\right)_{4}$ $(64.1 \mathrm{mg})$ in $0.7 \mathrm{~mL}$ of toluene- $\mathrm{d}_{8}-3 \mathrm{~min}$. after mixing. Colored arrows correspond to resonances from compounds $\mathbf{1 1}$ (blue), $\mathbf{1 3}$ (red) and $\mathbf{1 5}$ (magenta), respectively.

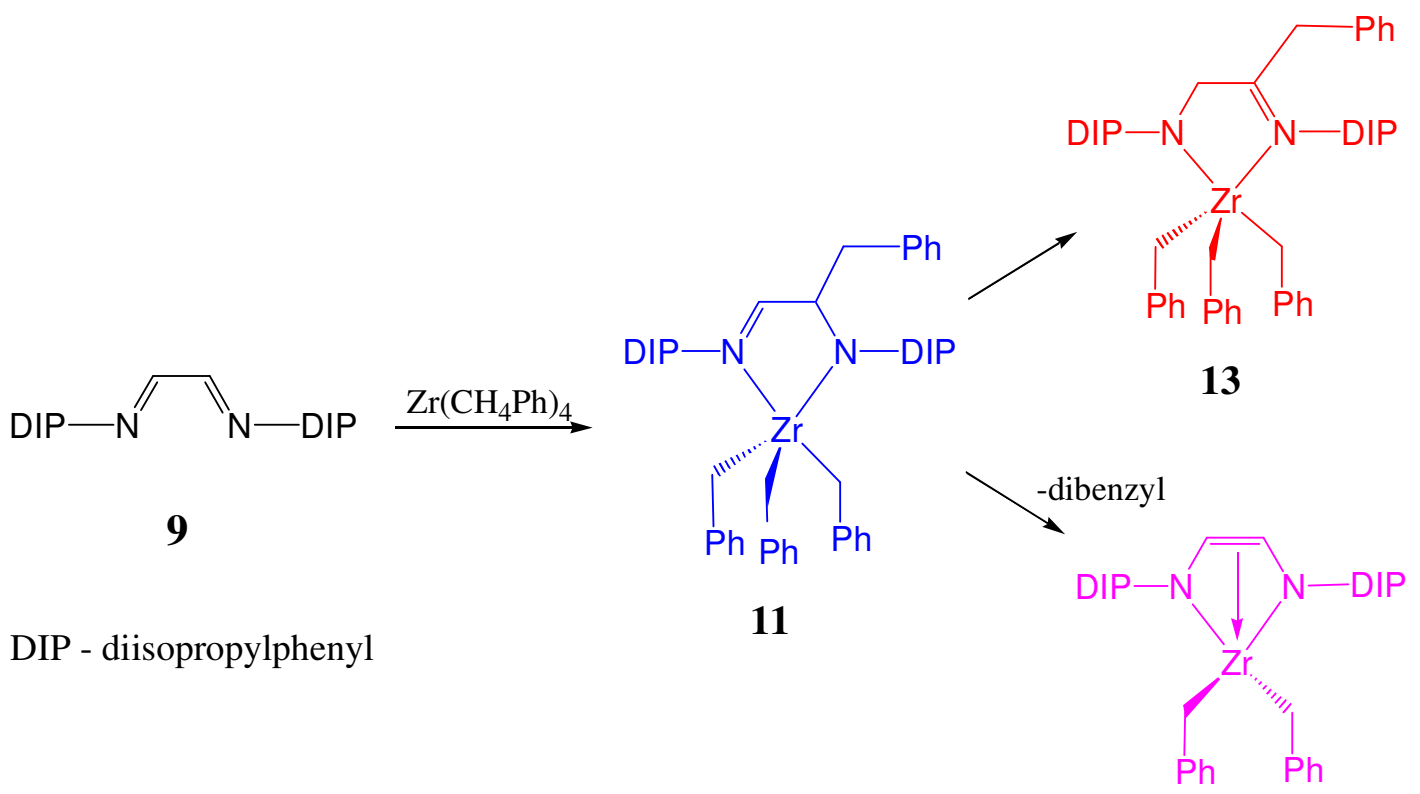

15

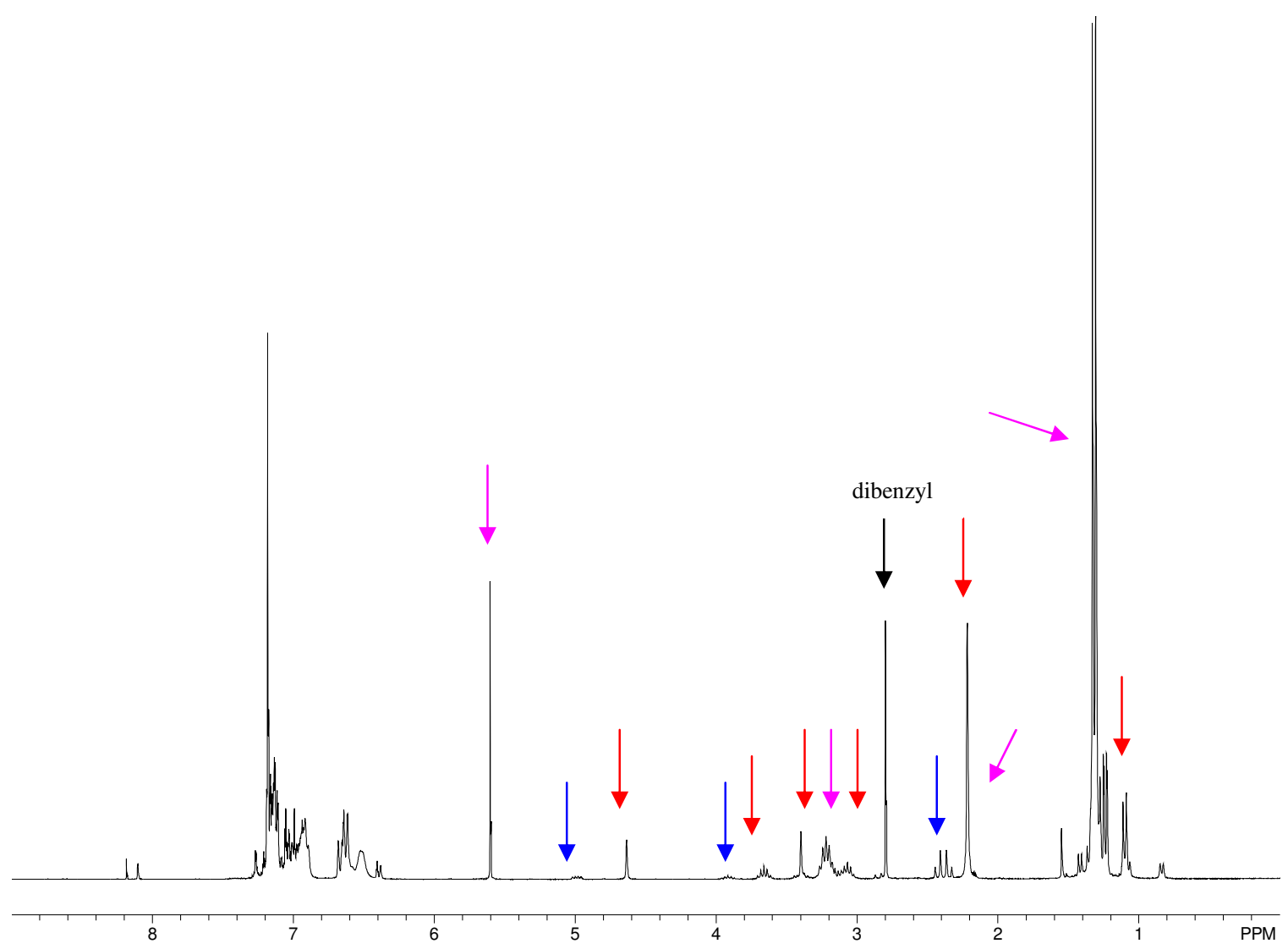


Figure 15. ${ }^{1} \mathrm{H}$ NMR spectrum of the reaction mixture between diimine $9(53 \mathrm{mg})$ and $\mathrm{Zr}\left(\mathrm{CH}_{2} \mathrm{Ph}\right)_{4}$ $\left(64.1 \mathrm{mg}\right.$ ) in $0.7 \mathrm{~mL}$ of toluene- $d_{8}-10 \mathrm{~min}$. (top spectrum) and $20 \mathrm{~min}$ (bottom spectrum) after mixing.
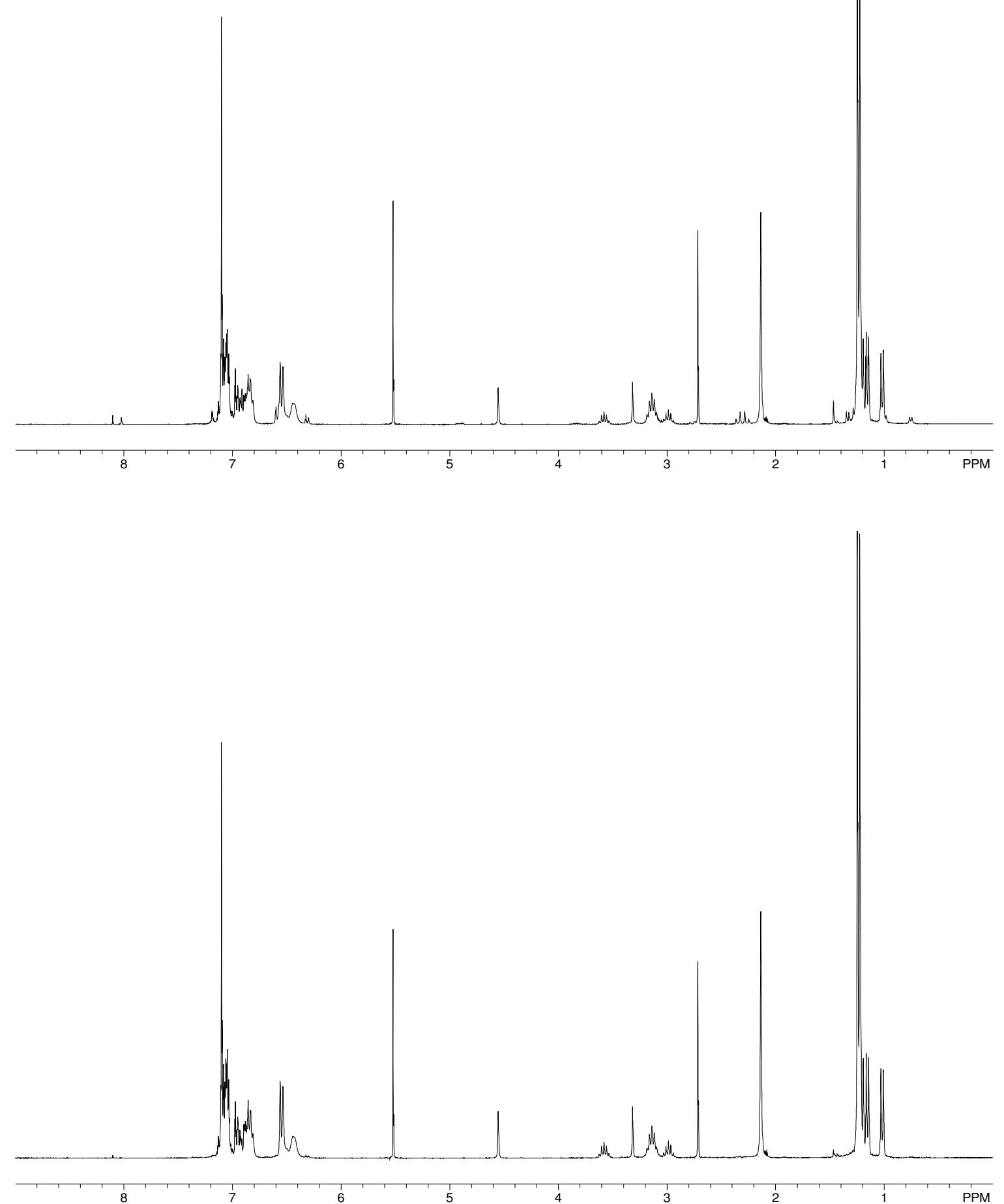
Figure 16. ${ }^{1} \mathrm{H}$ and APT spectra of $\mathbf{1 3}\left(\right.$ in $\left.\mathrm{CDCl}_{3}\right)$.
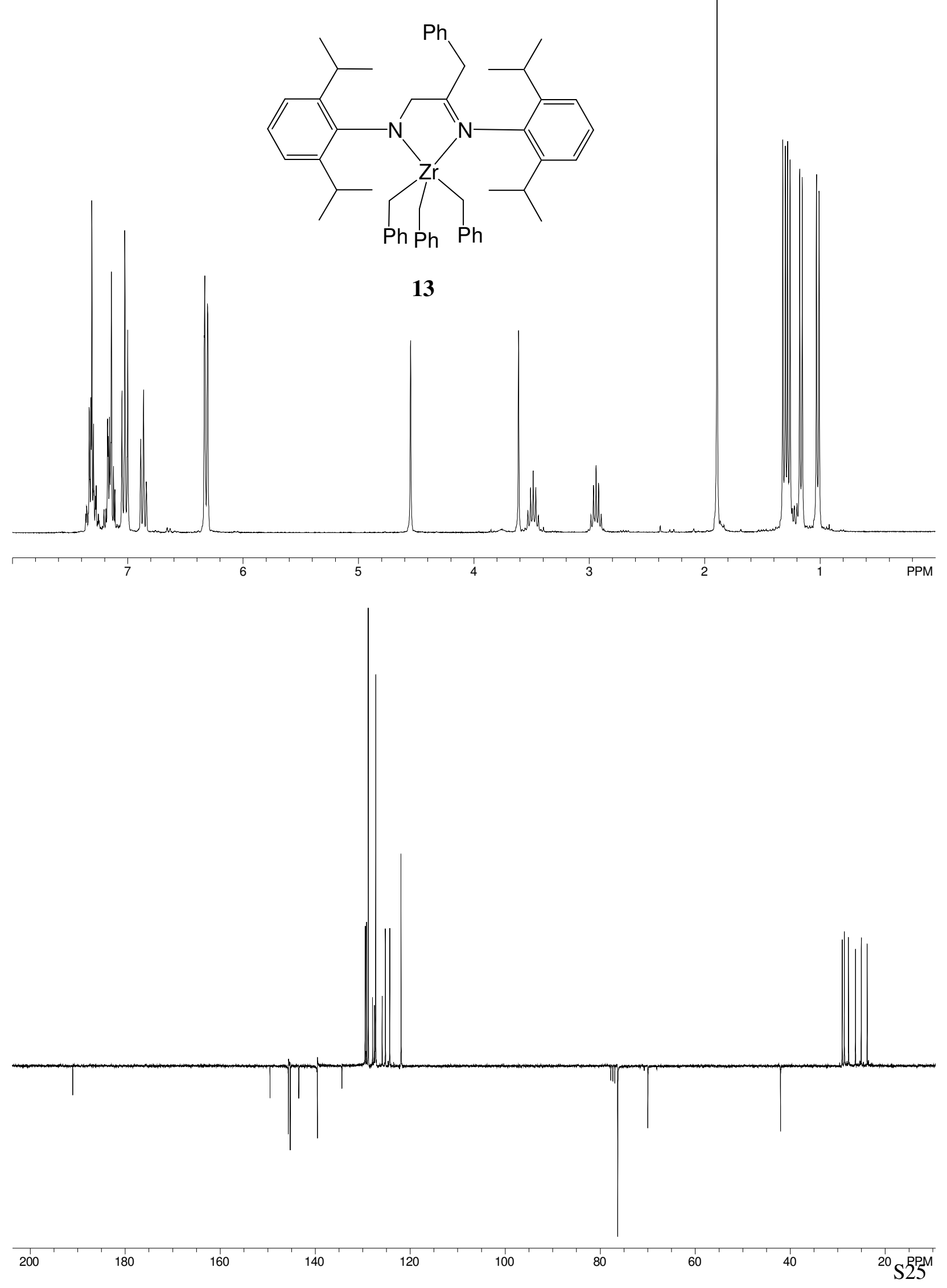
Figure 17. ${ }^{1} \mathrm{H}$ and APT spectra of $\mathbf{1 5}+$ dibenzyl (in toluene- $\mathrm{d}_{8}$ ).
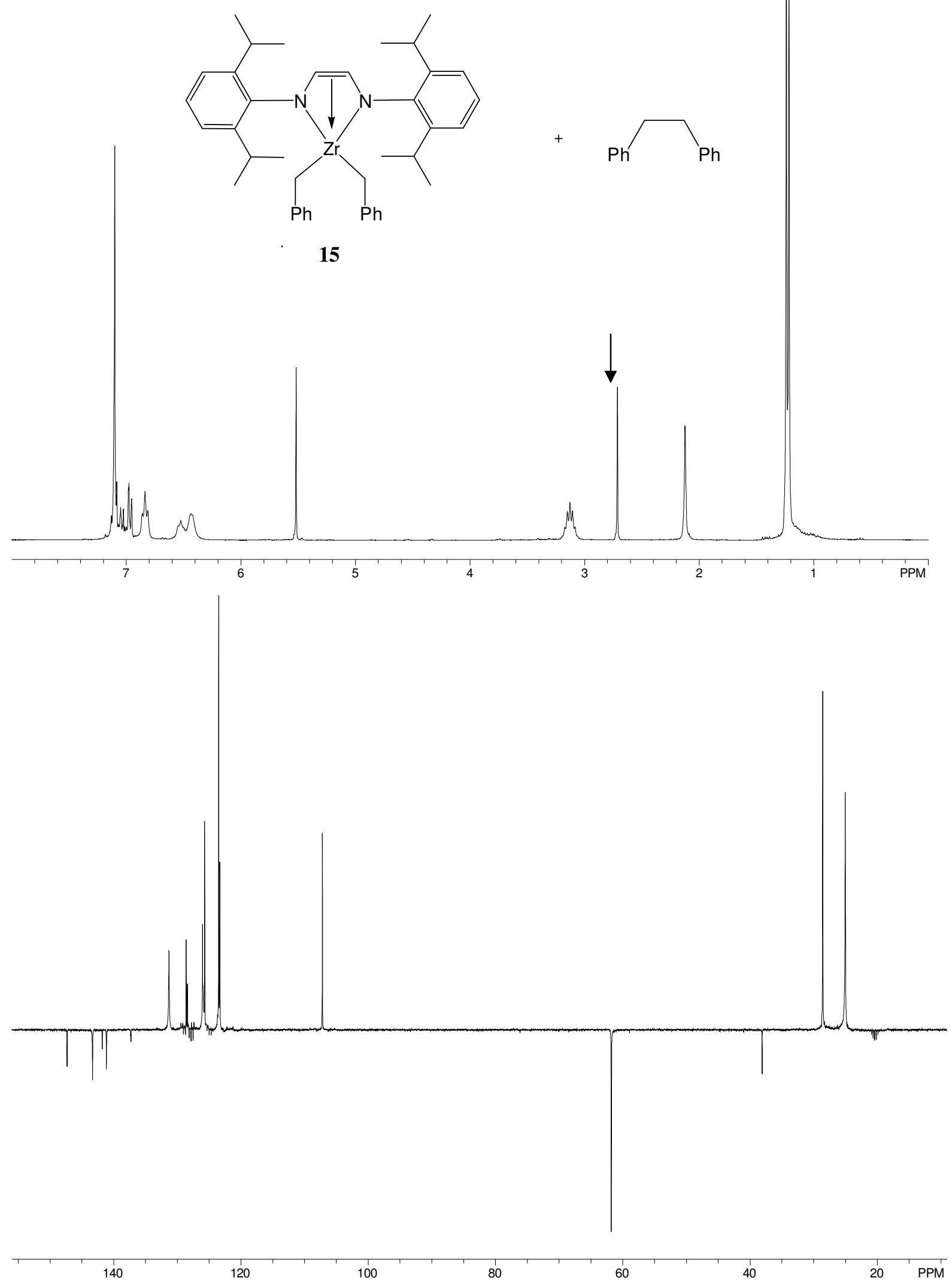
Decomposition Kinetics of 5. A stock solution was prepared by dissolving $252 \mathrm{mg}$ of $\mathbf{5}$ and 18 $\mathrm{mg}$ of ferrocene (used as internal standard) in $5 \mathrm{~mL}$ of toluene- $d_{8}$. Spectra were collected at 51.7, 59.5, 68.7 and $78.3{ }^{\circ} \mathrm{C}$ using the following parameters: number of transients $=32$ and acquisition time $=6 \mathrm{~s}$.

Rate constants (k) were obtained by least square analysis of non-linear form of first order equation. ${ }^{5}$ In this procedure concentration at the given time interval are calculated using nonlinear form of first order equation $\left[\mathrm{A}=\mathrm{A}_{\mathrm{o}} \mathrm{x} \exp (-\mathrm{kt})\right]$ and the rate constant $(\mathrm{k})$ and initial concentration (Ao) are adjusted until the sum of the error squared between the observed and calculated concentrations reaches a minimum. Microsoft Excel solver was used to perform this least square analysis.

Thermodynamic parameters $\left(\Delta \mathrm{H}^{\ddagger}\right.$ and $\left.\Delta \mathrm{S}^{\ddagger}\right)$ were obtained by least square analysis of non-linear form of Eyring equation 1. ${ }^{5}$ In this procedure rate constants are calculated using non-linear form of Eyring equation 1 and the $\Delta \mathrm{H}^{\ddagger}$ and $\Delta \mathrm{S}^{\ddagger}$ are adjusted until the sum of the error squared between the observed and calculated rate constants reaches a minimum. Microsoft Excel solver was used to perform this least square analysis. Calculation details are shown in Tables 2. This analysis gave $\Delta \mathrm{H}^{\ddagger}$ and $\Delta \mathrm{S}^{\ddagger}$ of 33(1) $\mathrm{kcal} / \mathrm{mol}, 20(3) \mathrm{cal} / \mathrm{mol}^{*} \mathrm{~K}$ respectively. Errors were obtained by nonlinear error analysis using SolvStat macro. ${ }^{6}$

\section{Eyring Equation}

$k=\frac{k_{B} T}{h} \times e^{-\frac{\Delta H^{\ddagger}}{R T}} \times e^{\frac{\Delta S^{\ddagger}}{R}}$

$\mathrm{k}_{\mathrm{B}}($ Boltzmann constant $)=1.3805 \times 10^{-16} \mathrm{erg} / \mathrm{K}, \mathrm{h}($ Planck's constant $)=6.626176 \times 10^{-27} \mathrm{erg} \mathrm{s}, \mathrm{R}$ $($ gas constant $\left.)=1.9872 \frac{\mathrm{cal} \times \mathrm{mol}}{\mathrm{deg}}\right)$

5. Espenson, J. H. Chemical Kinetics and Reaction Mechanisms, 2rd Edition, McGraw-Hill, 1995.

6. This was accomplished using SolvStat macro included in the book by Billo, E. J. Excel for Chemists, WileyVCH, 2nd Ed, 2001, Chapter 12. 
Figure 18. Stack plot of ${ }^{1} \mathrm{H}$ spectra of $\mathbf{5}$ (only resonance at $2.21 \mathrm{ppm}$ is shown) obtained at 70.5 ${ }^{\circ} \mathrm{C}$. Each spectrum was taken every $20 \mathrm{~min}$.

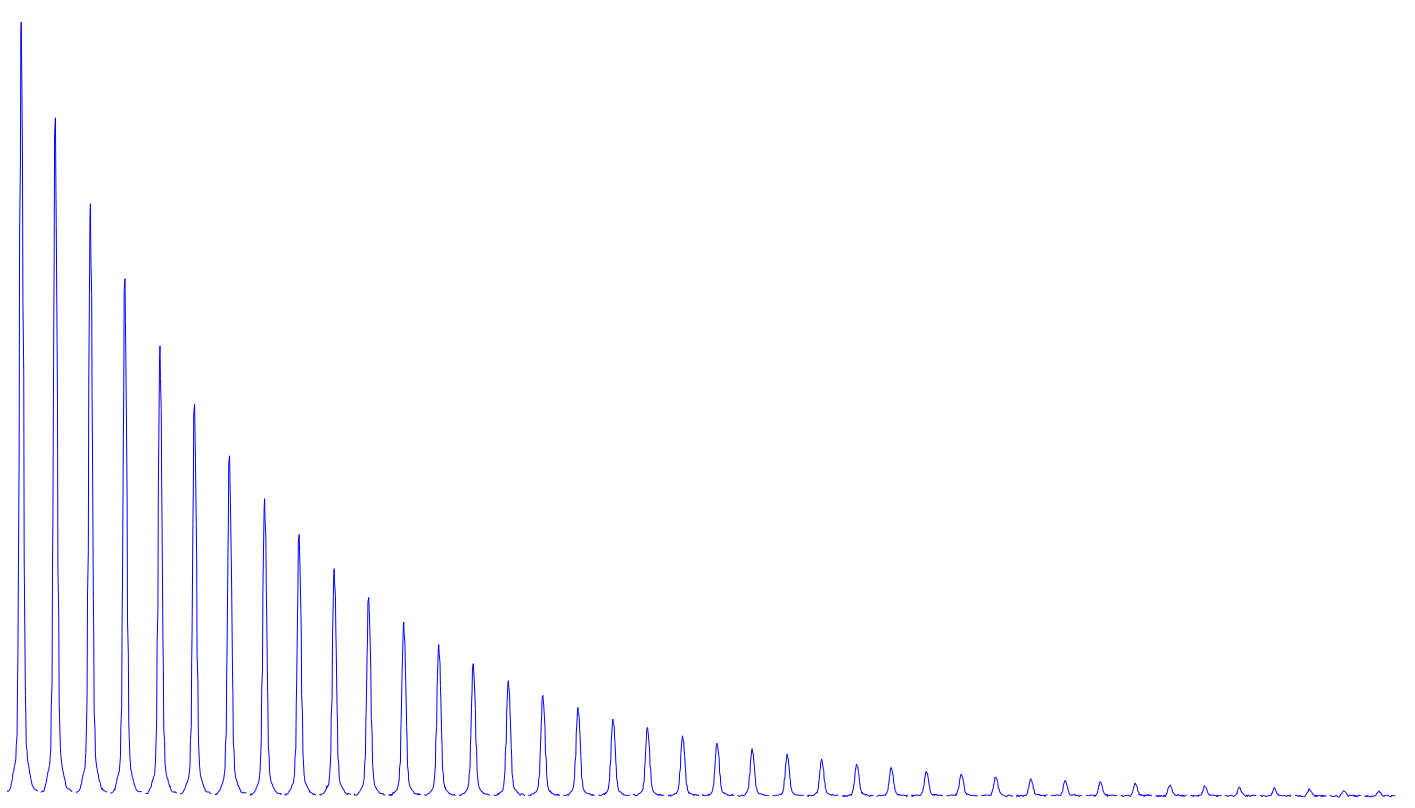

Table 1. Rate constant data for the decomposition of $\mathbf{5}$.

\begin{tabular}{|c|c|c|c|c|}
\hline Temp $\left({ }^{\circ} \mathrm{C}\right)$ & Temp $(\mathrm{K})$ & $\mathrm{k}$ (rate const.) & $1000 / \mathrm{T}(\mathrm{K}-1)$ & $\mathrm{Ln}(\mathrm{Kobs} / \mathrm{T})$ \\
\hline 78.3 & 351.46 & 0.0002988 & 2.845 & -13.978 \\
\hline 78.3 & 351.46 & 0.0003019 & 2.845 & -13.968 \\
\hline 78.3 & 351.46 & 0.0003096 & 2.845 & -13.942 \\
\hline 68.7 & 341.86 & 0.0000818 & 2.925 & -15.246 \\
\hline 68.7 & 341.86 & 0.0000795 & 2.925 & -15.275 \\
\hline 59.5 & 332.66 & 0.0000163 & 3.006 & -16.831 \\
\hline 59.5 & 332.66 & 0.0000159 & 3.006 & -16.856 \\
\hline 59.5 & 332.66 & 0.0000167 & 3.006 & -16.808 \\
\hline 51.7 & 324.86 & 0.0000054 & 3.078 & -17.913 \\
\hline
\end{tabular}


Figure 19. Eyring plot of the data shown in Table 1.

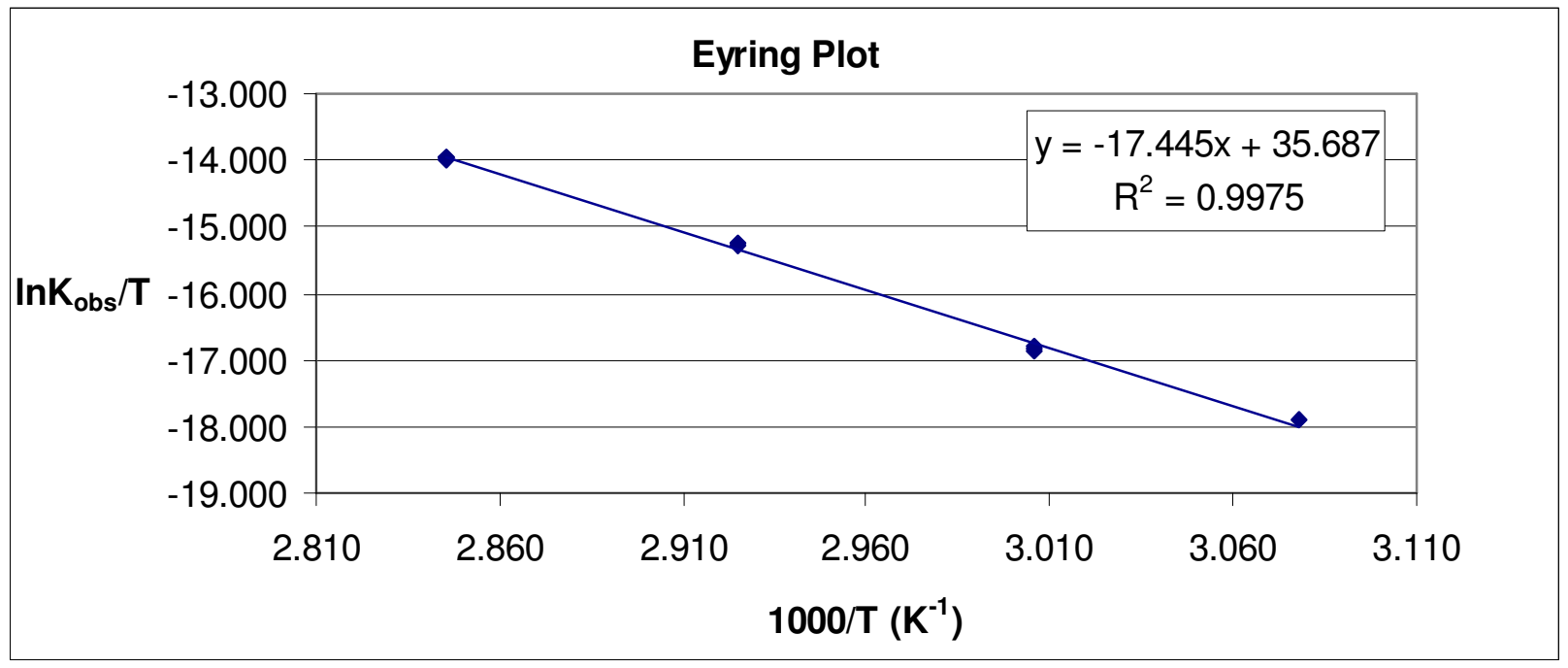

Table 2. Thermodynamic Calculations for decomposition of $\mathbf{5}$.

\begin{tabular}{|c|c|c|c|c|}
\hline Temp $\left({ }^{\circ} \mathrm{C}\right)$ & $\begin{array}{c}\text { Temp }(\mathrm{K}) \\
\mathrm{T}\end{array}$ & $\begin{array}{l}\text { Experimental } \\
\text { rate const. } \mathrm{k}\end{array}$ & $\begin{array}{c}\text { Calculated } \\
\text { rate constants } \mathrm{k}\end{array}$ & $\begin{array}{c}\text { Delta }^{\wedge} 2 \\
(\text { exp-calc })^{\wedge} 2\end{array}$ \\
\hline 78.3 & 351.46 & 0.0002988 & 0.0003038 & $2.5 E-11$ \\
\hline 78.3 & 351.46 & 0.0003019 & 0.0003038 & $3.6 \mathrm{E}-12$ \\
\hline 78.3 & 351.46 & 0.0003096 & 0.0003038 & $3.4 \mathrm{E}-11$ \\
\hline 68.7 & 341.86 & 0.0000818 & 0.0000774 & $2.0 \mathrm{E}-11$ \\
\hline 68.7 & 341.86 & 0.0000795 & 0.0000774 & $4.4 \mathrm{E}-12$ \\
\hline 59.5 & 332.66 & 0.0000163 & 0.0000194 & $9.5 E-12$ \\
\hline 59.5 & 332.66 & 0.0000159 & 0.0000194 & $1.2 \mathrm{E}-11$ \\
\hline 59.5 & 332.66 & 0.0000167 & 0.0000194 & $7.2 E-12$ \\
\hline 51.7 & 324.86 & 0.0000054 & 0.0000056 & $5.7 \mathrm{E}-14$ \\
\hline $\begin{array}{l}\Delta \mathrm{H}= \\
\Delta \mathrm{S}=\end{array}$ & $\begin{array}{c}33333 \\
19.9 \\
\end{array}$ & $\begin{array}{c}\mathrm{cal} / \mathrm{mol} \\
\mathrm{cal} / \mathrm{mol}^{\star} \mathrm{K}\end{array}$ & \multirow{2}{*}{$\begin{array}{c}\Delta \mathrm{H} \\
33.3 \\
0.6 \\
\end{array}$} & \multirow{2}{*}{$\begin{array}{l}\text { kcal } \\
\text { error }\end{array}$} \\
\hline \multirow{3}{*}{ Sqrt Sum } & \multirow{3}{*}{\multicolumn{2}{|c|}{$1.2 \mathrm{E}-04$}} & & \\
\hline & & & & \\
\hline & & & \multirow{4}{*}{$\begin{array}{c}\Delta S \\
19.9 \\
2.2\end{array}$} & \multirow{4}{*}{$\begin{array}{c}\mathrm{cal} / \mathrm{mol}^{\star} \mathrm{K} \\
\text { error }\end{array}$} \\
\hline $\mathrm{k}_{\mathrm{b}}=$ & $1.3805 \mathrm{E}-16$ & $\mathrm{erg} / \mathrm{K}$ & & \\
\hline$h=$ & $6.6256 \mathrm{E}-27$ & $\operatorname{erg} \mathrm{s}$ & & \\
\hline $\mathrm{cR}=$ & 1.9872 & $\mathrm{cal}^{*} \mathrm{~mol} / \mathrm{deg}$ & & \\
\hline
\end{tabular}


Figure 20. First order decomposition plots of $\mathbf{5}$.

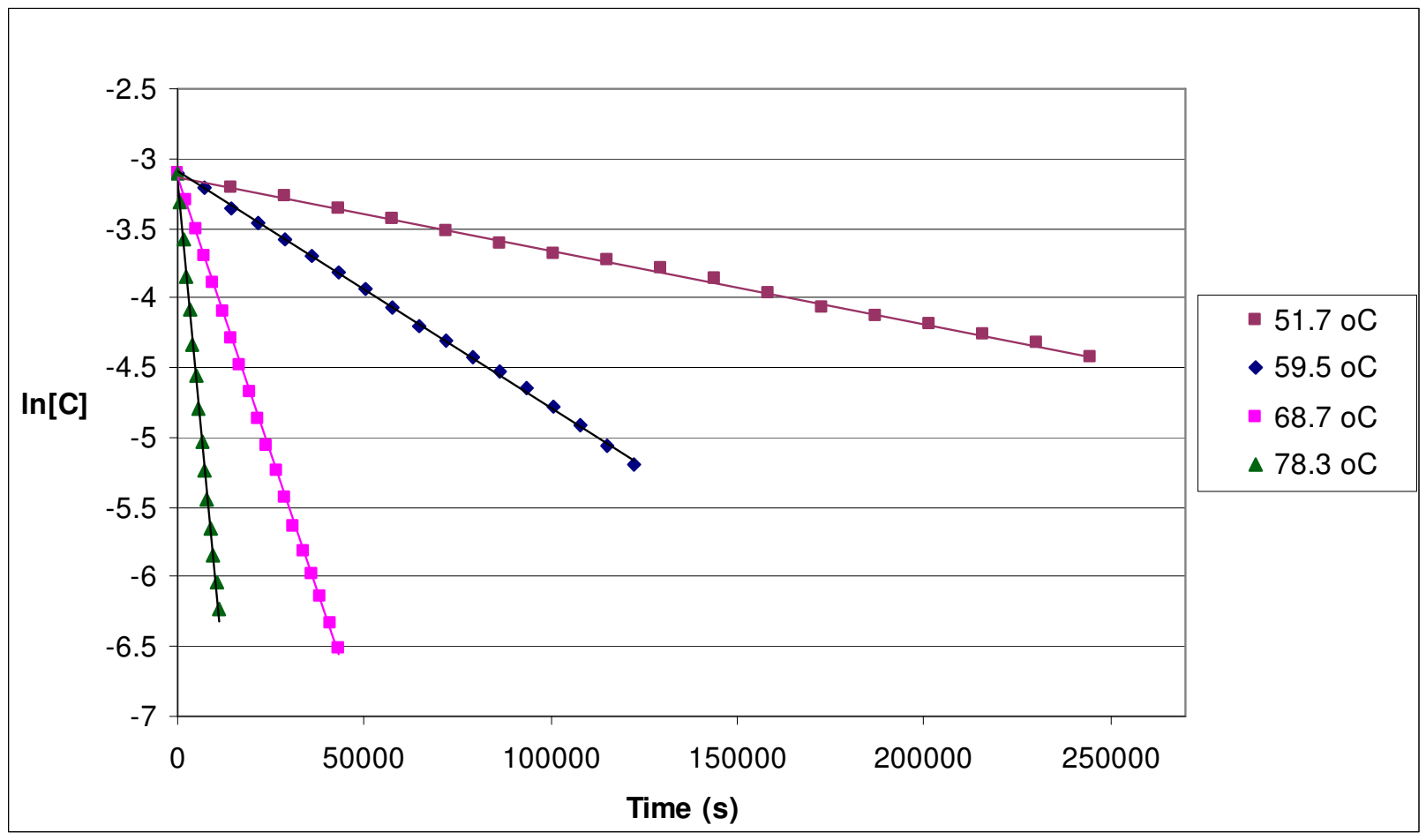

Decomposition Kinetics of 5 in the presence of TEMPO. Decomposition experiments with and without TEMPO were conducted at $70.5^{\circ} \mathrm{C}$. Solution Preparation: To a vial containing 100 $\mathrm{mg}$ of $5(0.05 \mathrm{mmol})$ was added $4 \mathrm{~g}$ of toluene- $d_{8}$ to form a solution. $2 \mathrm{~g}$ of this solution was taken and added to a vial containing $44 \mathrm{mg}$ of TEMPO ( $0.32 \mathrm{mmol}, 6$ equivalents) resulting in a homogeneous solution. Samples of both solutions were transferred to NMR tubes and decomposition was studied at $70.5^{\circ} \mathrm{C}$ (calibration with ethylene glycol). Ferrocene was not used as an internal standard as it interfered with resonances of 5 . The ${ }^{1} \mathrm{H}$ NMR spectra of the solution containing 5 and 6 equivalents of TEMPO is shown in Figure 21. Broadness of the peaks in the top spectrum is caused by the presence of large amount of TEMPO.

After thermolysis, the reaction mixture was analyzed by GCMS and ES-MS. Based on ${ }^{1} \mathrm{H}$ NMR and GCMS the organic product was assigned to $\mathrm{C}_{6} \mathrm{H}_{5} \mathrm{CH}_{2}$-TEMPO. Proton chemical shifts were identical to those reported previously for this compound. ${ }^{7}$ ES-MS indicates that the organometallic species formed during this reaction is (diazabutadiene)-Hf(TEMPO) 2 . Decomposition plots are shown in Figure 22.

7. Nomura, M.; Takayama, C.; Kajitani, M. Inorg. Chem. 2003, 42, 6441-6446. 
Figure 21. ${ }^{1} \mathrm{H}$ NMR spectra of 5 in the presence of six equiv. of TEMPO after $10 \mathrm{~min}$. (top) and $14 \mathrm{~h}$ (bottom) at $70.5^{\circ} \mathrm{C}$.
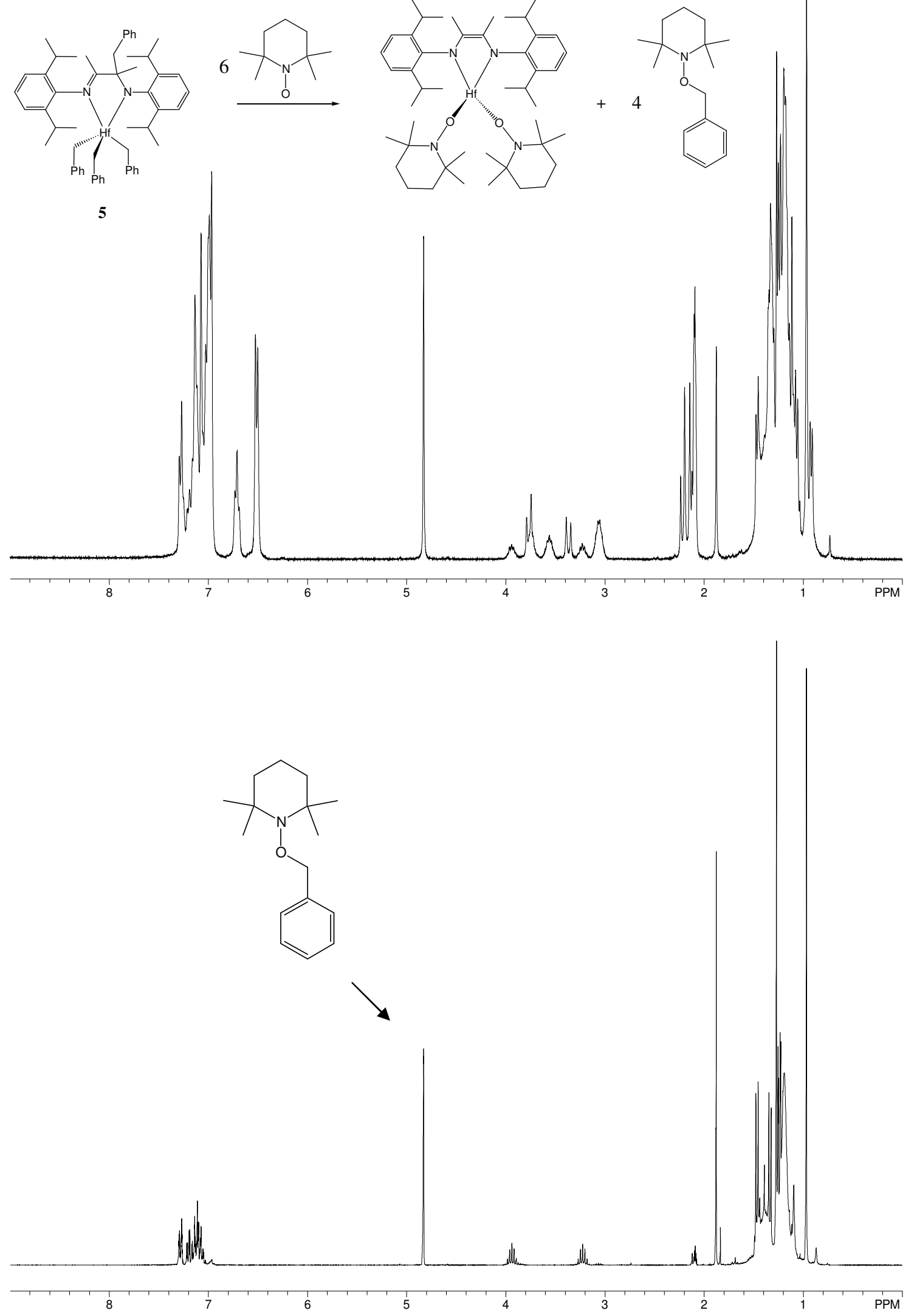
Figure 22. First order decomposition plots of 5 at $70.5^{\circ} \mathrm{C}$ with (6 equiv.) and without TEMPO (experimental and calculated values).

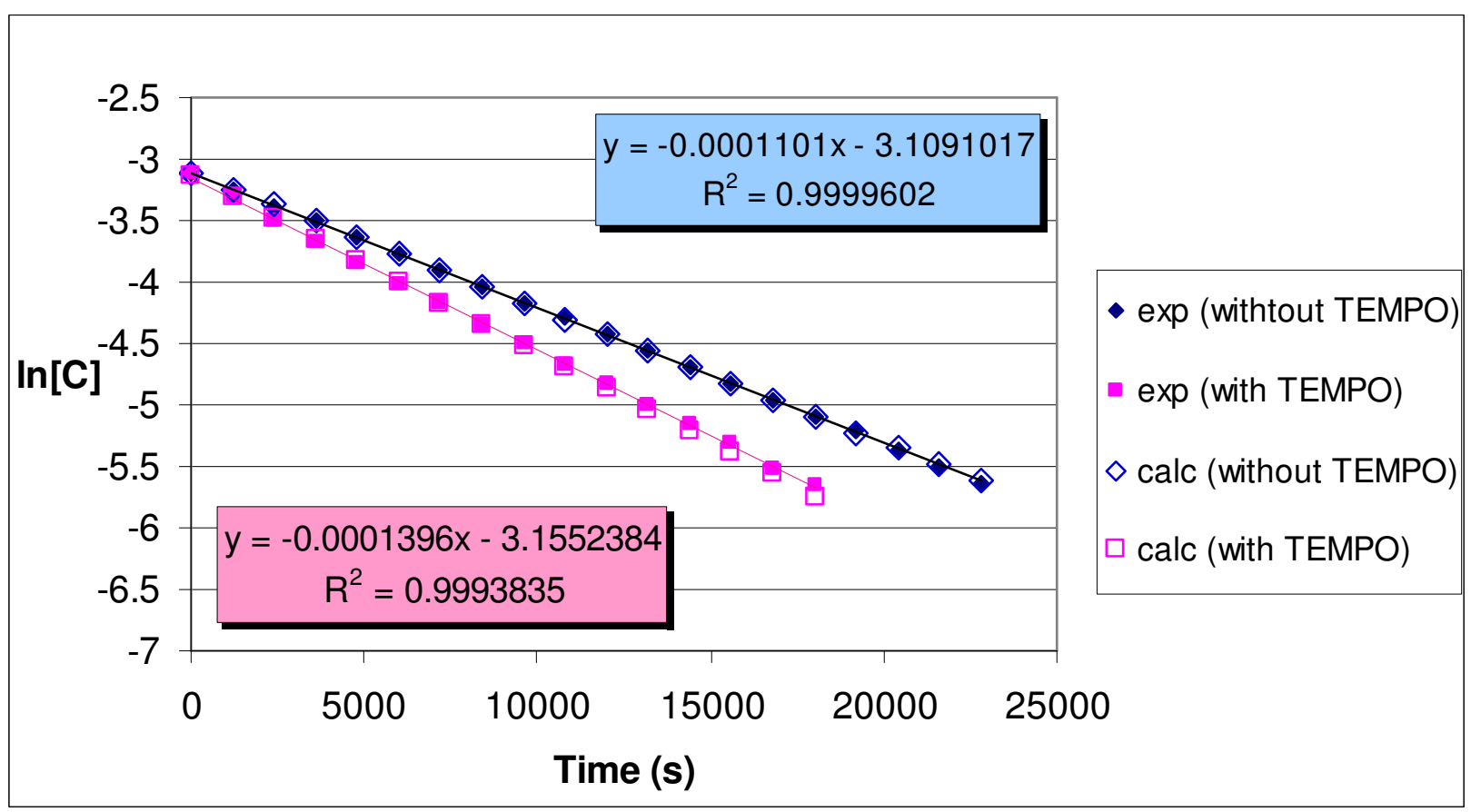




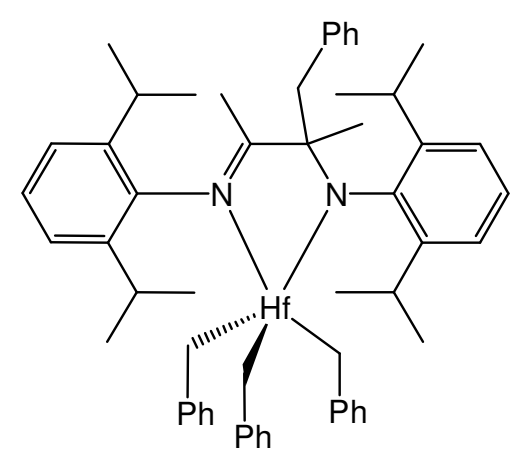

5

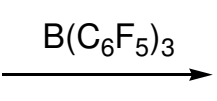

Synthesis of 16. To a vial containing $35.5 \mathrm{mg}(0.07 \mathrm{mmol})$ of $\mathrm{B}\left(\mathrm{C}_{6} \mathrm{~F}_{5}\right)_{3}$ was added $65.8 \mathrm{mg}(0.07$ $\mathrm{mmol}$ ) of 5 followed by addition of $0.8 \mathrm{~mL}$ of $\mathrm{C}_{6} \mathrm{D}_{6}$. After about $20 \mathrm{~s}$ the solution became cloudy and an oil separated from yellow solution. To this vial was added $2 \mathrm{~mL}$ of hexane causing further separation. After $10 \mathrm{~min}$. solvent was decanted and more hexane $(3 \mathrm{~mL})$ was added. After shaking the vial for 15 seconds hexane wash was decanted and the residue was dried under reduced pressure (yellow solid foamed during drying) to give $75 \mathrm{mg}$ of product. Yield $73 \%$. The product $\left(23 \mathrm{mg}\right.$ ) was dissolved in $0.6 \mathrm{~mL} \mathrm{C}_{6} \mathrm{D}_{5} \mathrm{Cl}$. NMR spectra of this material are shown below.

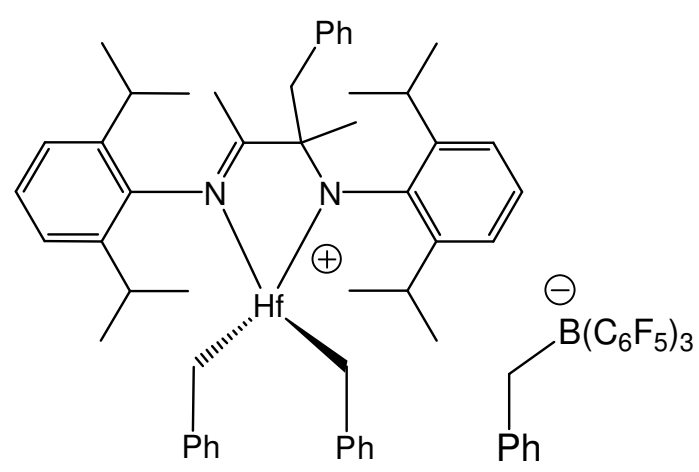

16 
Figure 23. ${ }^{1} \mathrm{H}$ and ${ }^{13} \mathrm{C}\left\{{ }^{1} \mathrm{H}\right\}$ spectra of $\mathbf{1 6}$.
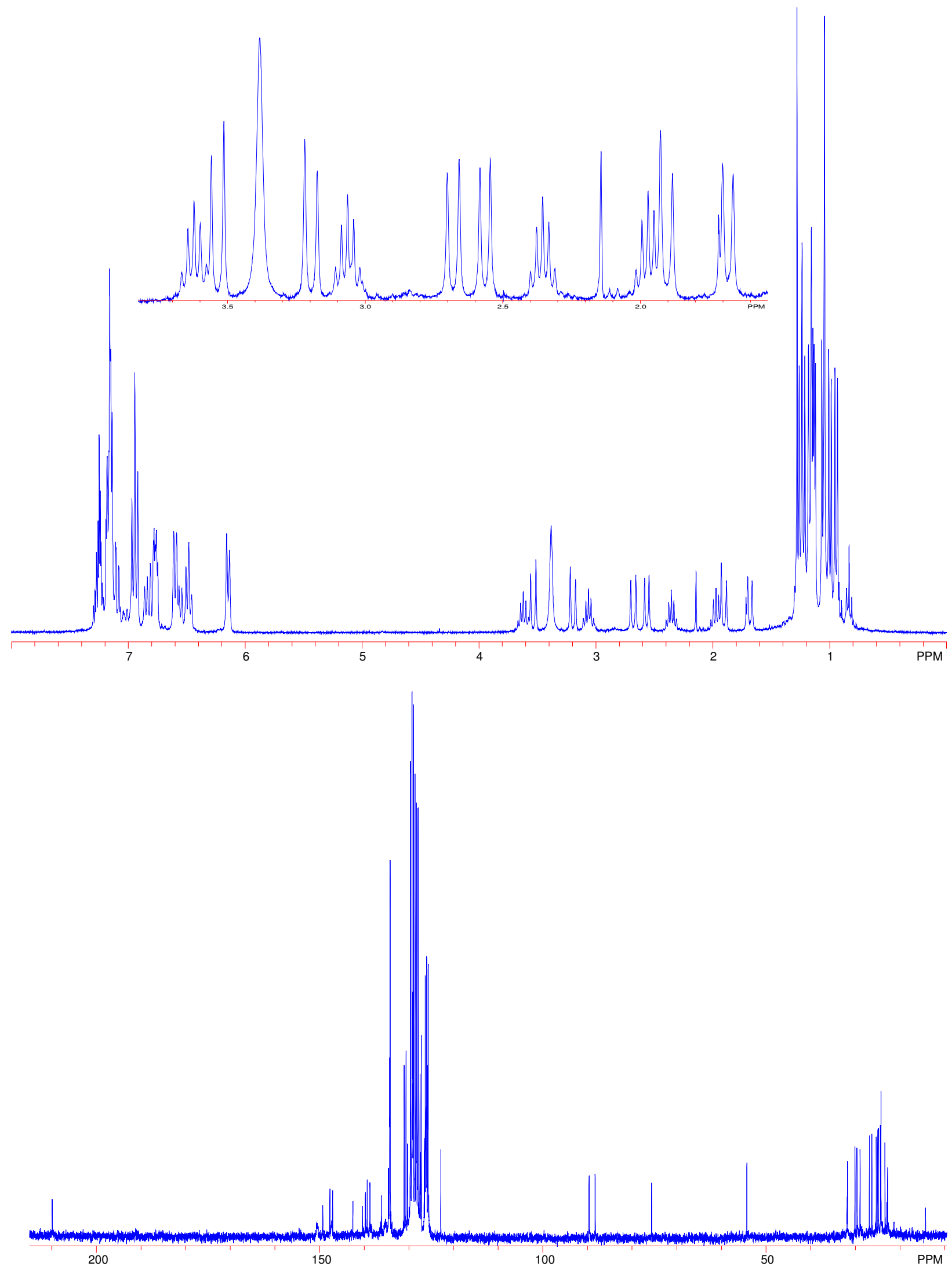
Figure 24. ${ }^{1} \mathrm{H}$ spectrum of $\mathbf{1 6 .}$

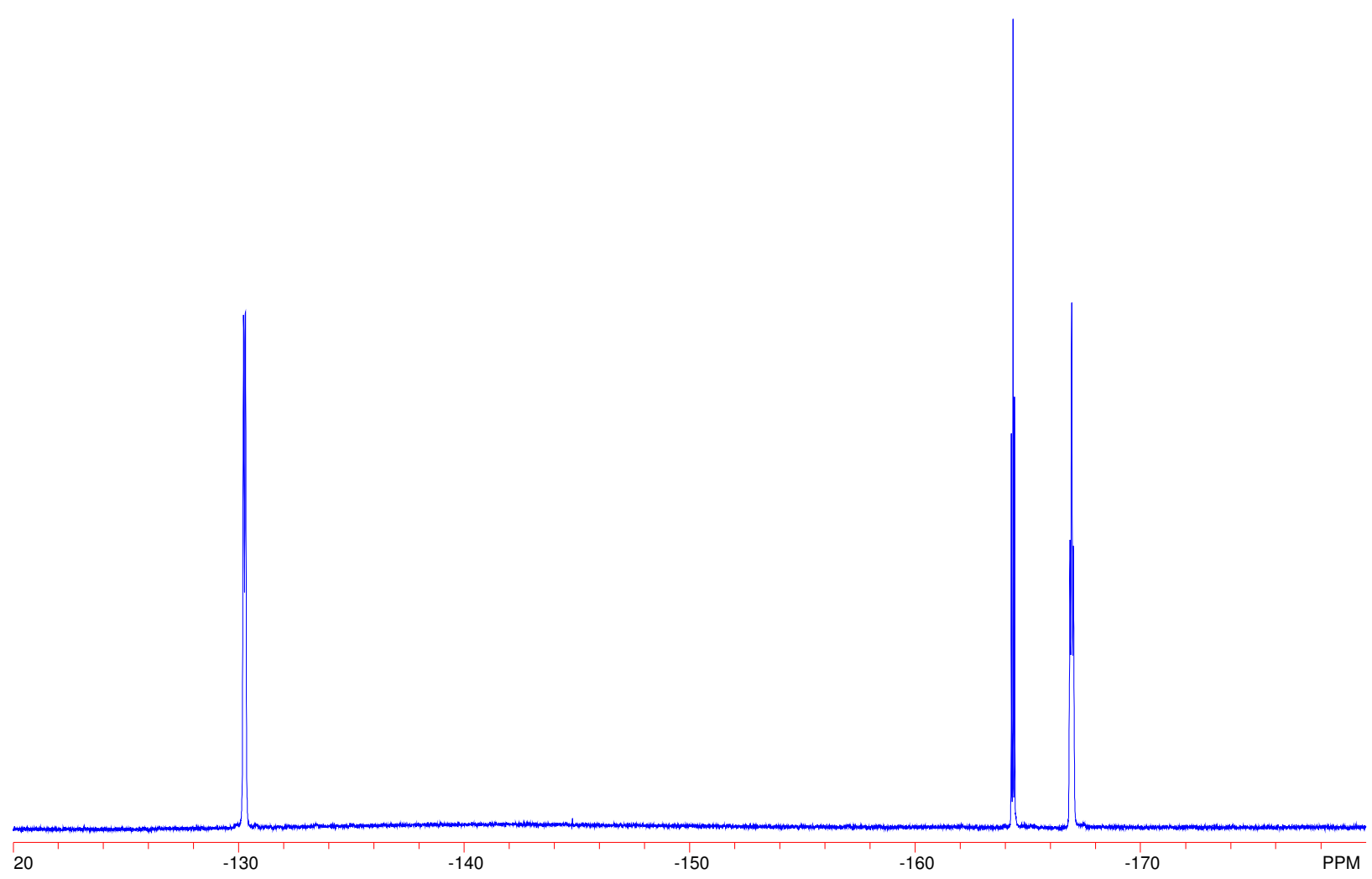


Figure 25. COSY spectra of $\mathbf{1 6}$.
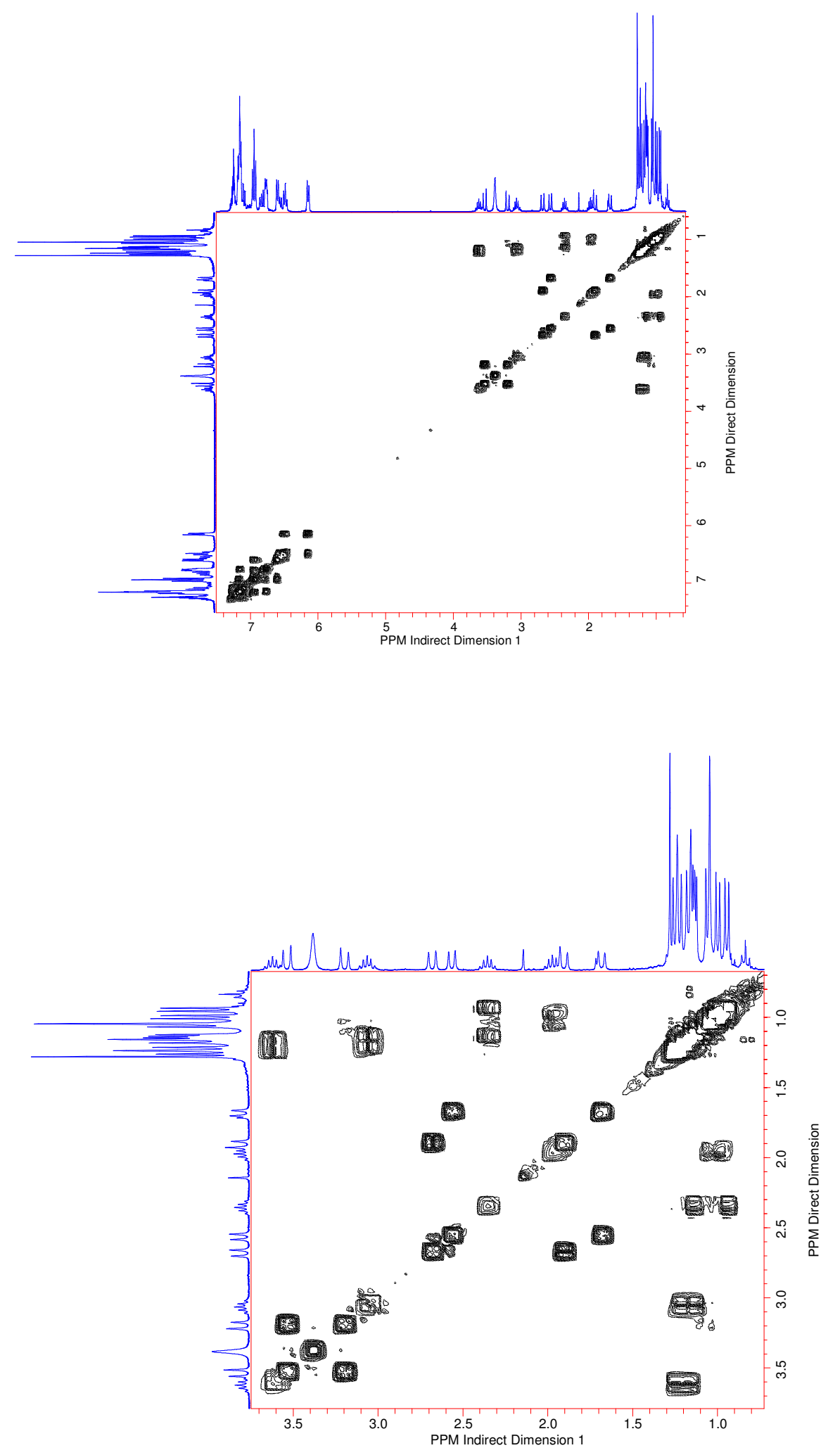


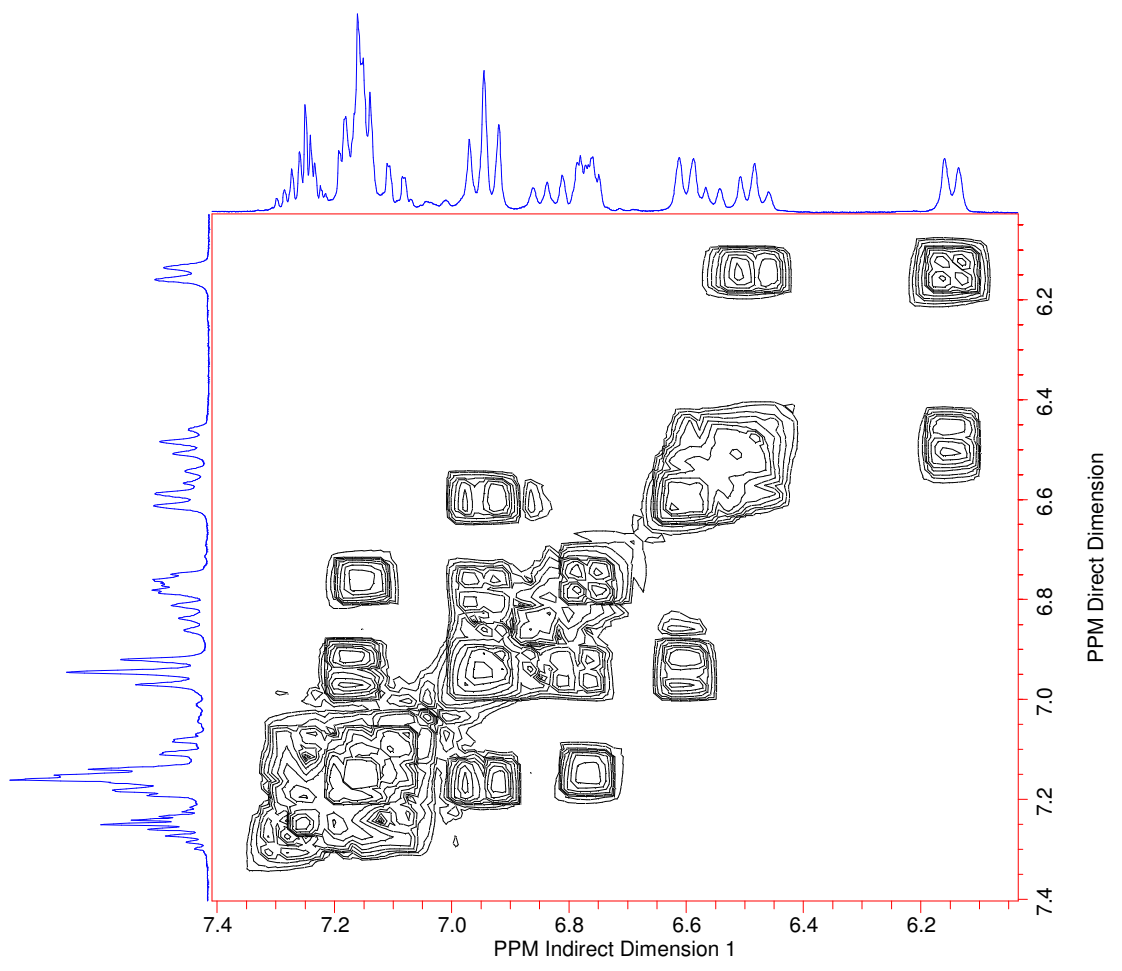


Figure 26. NOESY spectra of $\mathbf{1 6}$.
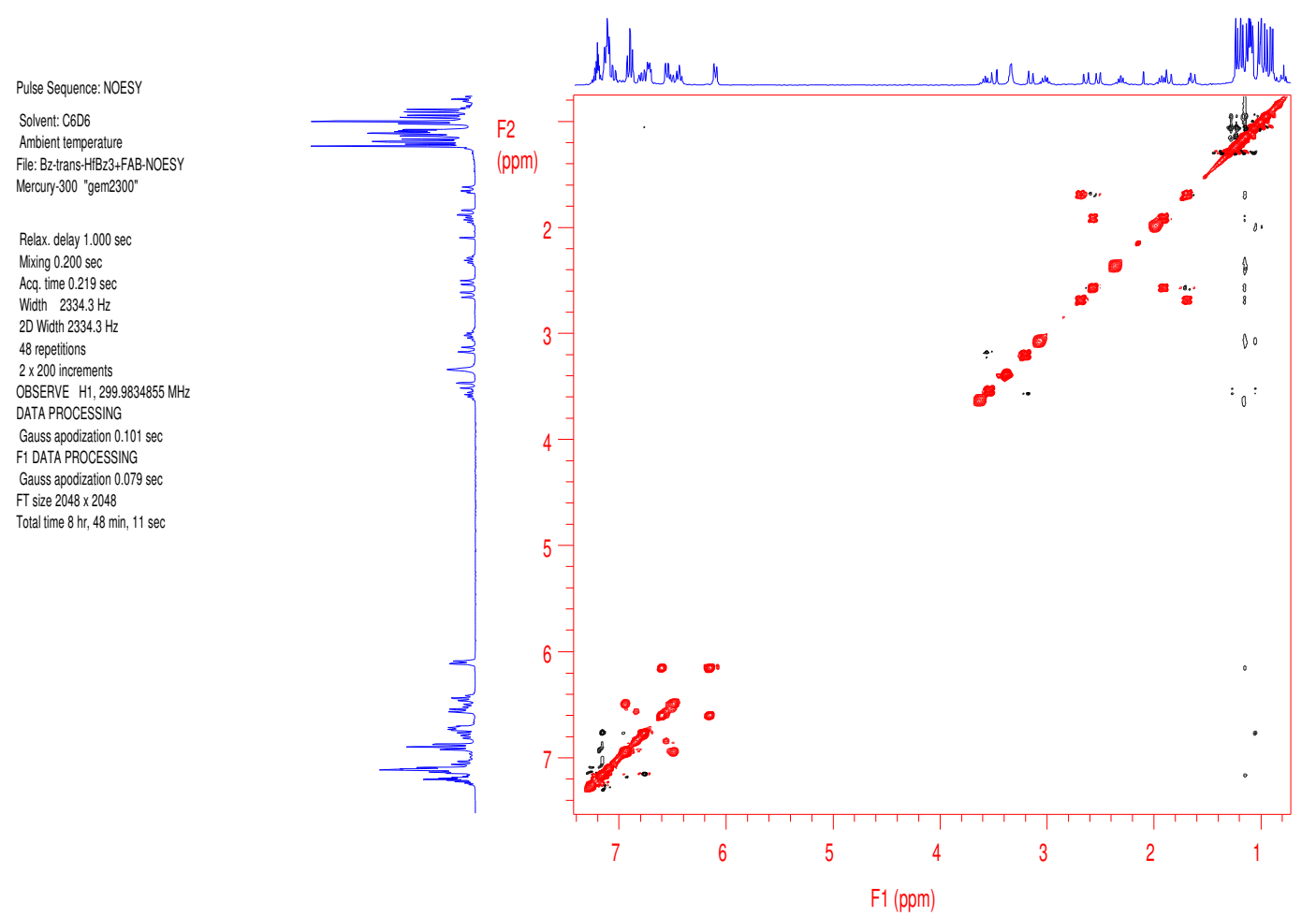
Figure 27. NOESY1D spectra of 16. Mixing times $0.05,0.1,0.2,0.4,0.8 \mathrm{~s}$.

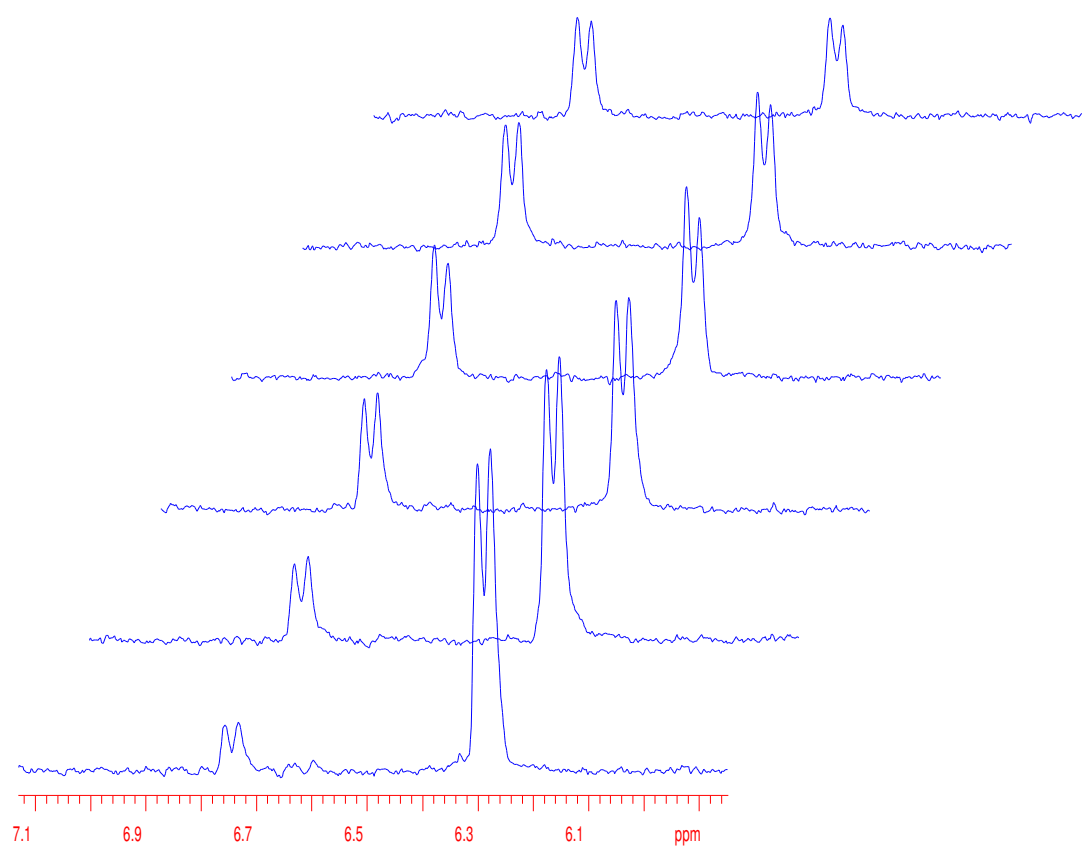

Magnetization transfer experiments and data analysis (Table 3, Figure 28) were conducted according to procedure published elsewhere. ${ }^{8}$

8. Arriola, D. J.; Bakota, M. Campbell, R. E.; Klosin, J.; LaPointe, R. E.; Redwine, O. D.;Shankar,R. B.; Timmers, F. J. J. Am. Chem. Soc. 2007, 129, 7065-7076. 
Table 3. Analysis of EXSY data $\left(28^{\circ} \mathrm{C}\right)$.

\begin{tabular}{|c|c|c|c|c|c|c|}
\hline $\begin{array}{l}\text { Mixing } \\
\text { time }(\mathrm{t})\end{array}$ & $\begin{array}{l}\text { Intensity of A } \\
\text { (experimental) }\end{array}$ & $\begin{array}{c}\text { Intensity of B } \\
\text { (experimental) }\end{array}$ & $\begin{array}{c}\text { Intensity of A } \\
\text { (calculated) }\end{array}$ & $\begin{array}{c}\text { Intensity of B } \\
\text { (calculated) }\end{array}$ & $\begin{array}{l}\text { Delta Int. A } \\
\text { (cal-exp)^2 }\end{array}$ & $\begin{array}{l}\text { Delta Int. B } \\
\text { (cal-exp)^2 }\end{array}$ \\
\hline 0.05 & 1000 & 139.6 & 1002.86 & 142.33 & 8.18 & 7.47 \\
\hline 0.1 & 861 & 239 & 858.05 & 236.51 & 8.71 & 6.21 \\
\hline 0.2 & 653 & 330 & 662.08 & 337.83 & 82.39 & 61.24 \\
\hline 0.3 & 547 & 375 & 541.30 & 372.14 & 32.53 & 8.19 \\
\hline 0.4 & 470 & 385 & 461.35 & 373.10 & 74.90 & 141.68 \\
\hline 0.8 & 290 & 278 & 293.83 & 287.30 & 14.70 & 86.43 \\
\hline Ao & 1194.8 & & & Sqrt Sum & 532.64 & \\
\hline Bo & 3.4 & & & & & \\
\hline k & 2.80 & at 28 oC & & & & \\
\hline $\mathrm{kd}$ & 0.90 & & & & & \\
\hline
\end{tabular}

$\mathrm{A}_{\mathrm{o}}, \mathrm{B}_{\mathrm{o}}$ are calculated resonance integrals of $\mathrm{A}$ and $\mathrm{B}$ at $\mathrm{t}=0, \mathrm{k}$ is calculated chemical exchange rate constant, $t$ is mixing time, $k_{d}$ (inverse of $T_{1}$ ) is calculated relaxation rate for $A$ and $B$.

Figure 28. Analysis of EXSY data at $28^{\circ} \mathrm{C}$.

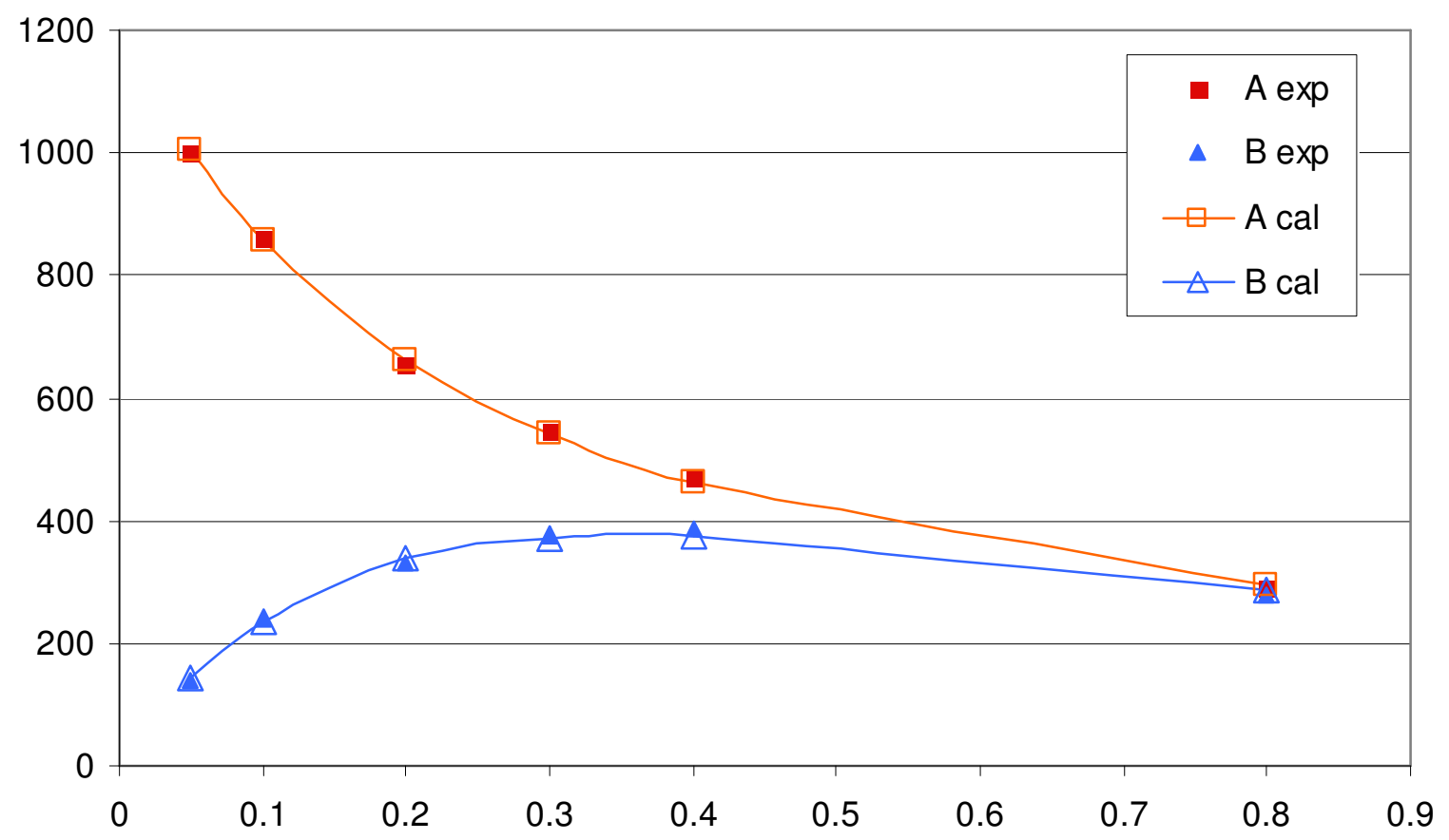


Single crystal X-ray data. Crystals were sealed under a nitrogen atmosphere in a glass capillary. The sample was optically aligned on the four-circle of a Siemens P4 diffractometer equipped with a graphite monochromator, a monocap collimator, a Mo $K \alpha$ radiation source $(\lambda=0.71073$ $\AA$ ), and a SMART CCD detector held at $5.082 \mathrm{~cm}$ from the crystal. The diffraction data were collected while cooling the sample to $-50^{\circ} \mathrm{C}$ with a nitrogen gas stream generated by a LT-2 low temperature attachment. The program SMART (version 5.6) ${ }^{9}$ was used for diffractometer control, frame scans, indexing, orientation matrix calculations, least-squares refinement of cell parameters, and the data collection. Crystallographic raw data frames were read by program SAINT (version 5/6.0) ${ }^{1}$ and integrated using 3D profiling algorithms. An absorption correction was applied using the SADABS routine available in SAINT. ${ }^{9}$ The data were corrected for Lorentz and polarization effects. Data preparation was carried out by using the program XPREP. ${ }^{9}$ The structures were solved by a combination of direct methods and difference Fourier analysis with the use of SHELXTL 6.1. ${ }^{10}$ Idealized positions for the hydrogen atoms were included as fixed contributions using a riding model with isotropic temperature factors set at 1.2 (aromatic, methylene, and methine hydrogens) or 1.5 (methyl hydrogens) times that of the adjacent non-hydrogen atom. The positions of the methyl hydrogen atoms were optimized by a rigid rotating group refinement with idealized tetrahedral angles. Full-matrix least-squares refinement, based upon the minimization of $\Sigma \mathrm{w}_{\mathrm{i}}\left|\mathrm{F}_{\mathrm{o}}{ }^{2}-\mathrm{F}_{\mathrm{c}}{ }^{2}\right|^{2}$, with weighting $\mathrm{w}_{\mathrm{i}}^{-1}=\left[\sigma^{2}\left(\mathrm{~F}_{\mathrm{o}}^{2}\right)+\right.$ $\left.(0.0494 \mathrm{P})^{2}+1.5197 \mathrm{P}\right]$, where $\mathrm{P}=\left(\operatorname{Max}\left(\mathrm{F}_{\mathrm{o}}^{2}, 0\right)+2 \mathrm{~F}_{\mathrm{c}}^{2}\right) / 3$, converged to give final discrepancy indices $^{11}$ of R1 $=0.0396, w R 2=0.0910$ for 15728 with $\mathrm{I}>2 \sigma(\mathrm{I})$ for $\mathbf{5}, \mathrm{R} 1=0.0287, \mathrm{wR} 2=$ 0.0689 for 5914 with $\mathrm{I}>2 \sigma(\mathrm{I})$ for $7, \mathrm{R} 1=0.0372$, wR2 $=0.1004$ for 7299 with $\mathrm{I}>2 \sigma(\mathrm{I})$ for 8 and $\mathrm{R} 1=0.0409, \mathrm{wR} 2=0.1094$ for 8461 with $\mathrm{I}>2 \sigma(\mathrm{I})$ for 13 .

9. SMART, SAINT and XPREP programs are part of Bruker crystallographic software package for single crystal data collection, reduction and preparation.

10. Sheldrick, G. M., SHELXTL6.1 (2000), Crystallographic software package, Bruker AXS, Inc. Madison, Wisconsin, USA.

11. $\mathrm{R}_{1}=\sum\left(\left\|\mathrm{F}_{\mathrm{O}}|-| \mathrm{F}_{\mathrm{C}}\right\|\right) / \sum\left|\mathrm{F}_{\mathrm{O}}\right|, \mathrm{wR}_{2}=\left[\sum\left[\mathrm{w}\left(\mathrm{F}_{\mathrm{O}}{ }^{2}-\mathrm{F}_{\mathrm{c}}{ }^{2}\right)^{2}\right] / \sum\left[\mathrm{w}\left(\mathrm{F}_{\mathrm{O}}{ }^{2}\right)^{2}\right]\right]^{1 / 2}, \mathrm{R}_{\text {int. }}=\sum\left|\mathrm{F}_{\mathrm{O}}{ }^{2}-\mathrm{F}_{\mathrm{O}}{ }^{2}(\mathrm{mean})\right|^{2} / \sum\left[\mathrm{F}_{\mathrm{O}}{ }^{2}\right]$, and $\mathrm{GOF}=\left[\Sigma\left[\mathrm{w}\left(\mathrm{F}_{\mathrm{O}}{ }^{2}-\mathrm{F}_{\mathrm{c}}{ }^{2}\right)^{2}\right] /(\mathrm{n}-\mathrm{p})\right]^{1 / 2}$, where $\mathrm{n}$ is the number of reflections and $\mathrm{p}$ is the total number of parameters which were varied during the last refinement cycle. 
A correction for secondary extinction was not applied. The linear absorption coefficient, atomic scattering factors, and anomalous dispersion corrections were calculated from values found in the International Tables of X-ray Crystallography. ${ }^{12}$

12. International Tables for X-ray Crystallography (1974). Vol. IV, p. 55. Birmingham: Kynoch Press. (Present distributor, D. Reidel, Dordrecht.). 


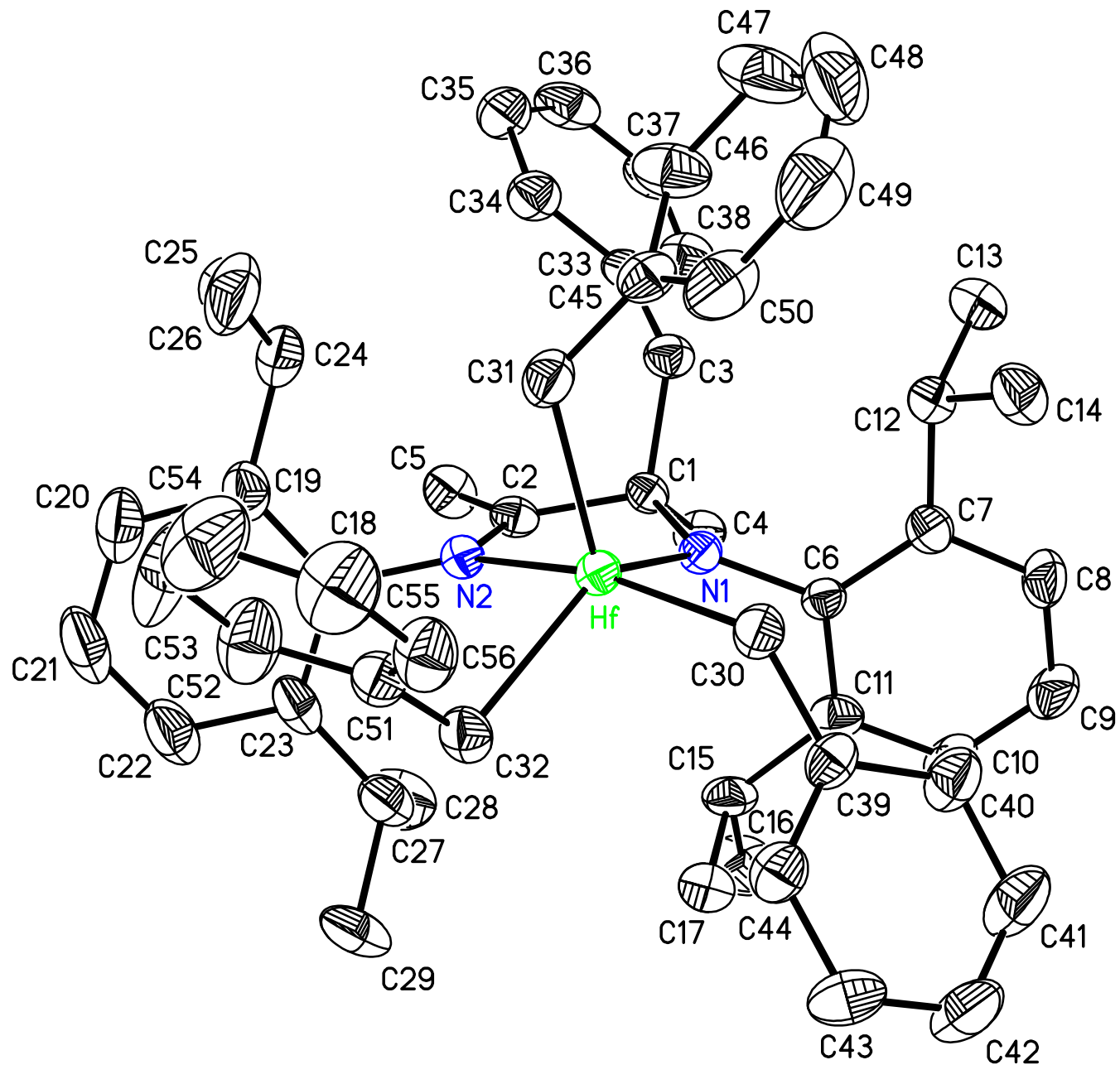

Figure 29. Molecular structure of 5 with full labeling scheme. Hydrogen atoms were removed for clarity. Thermal ellipsoids are shown at $40 \%$ probability. 


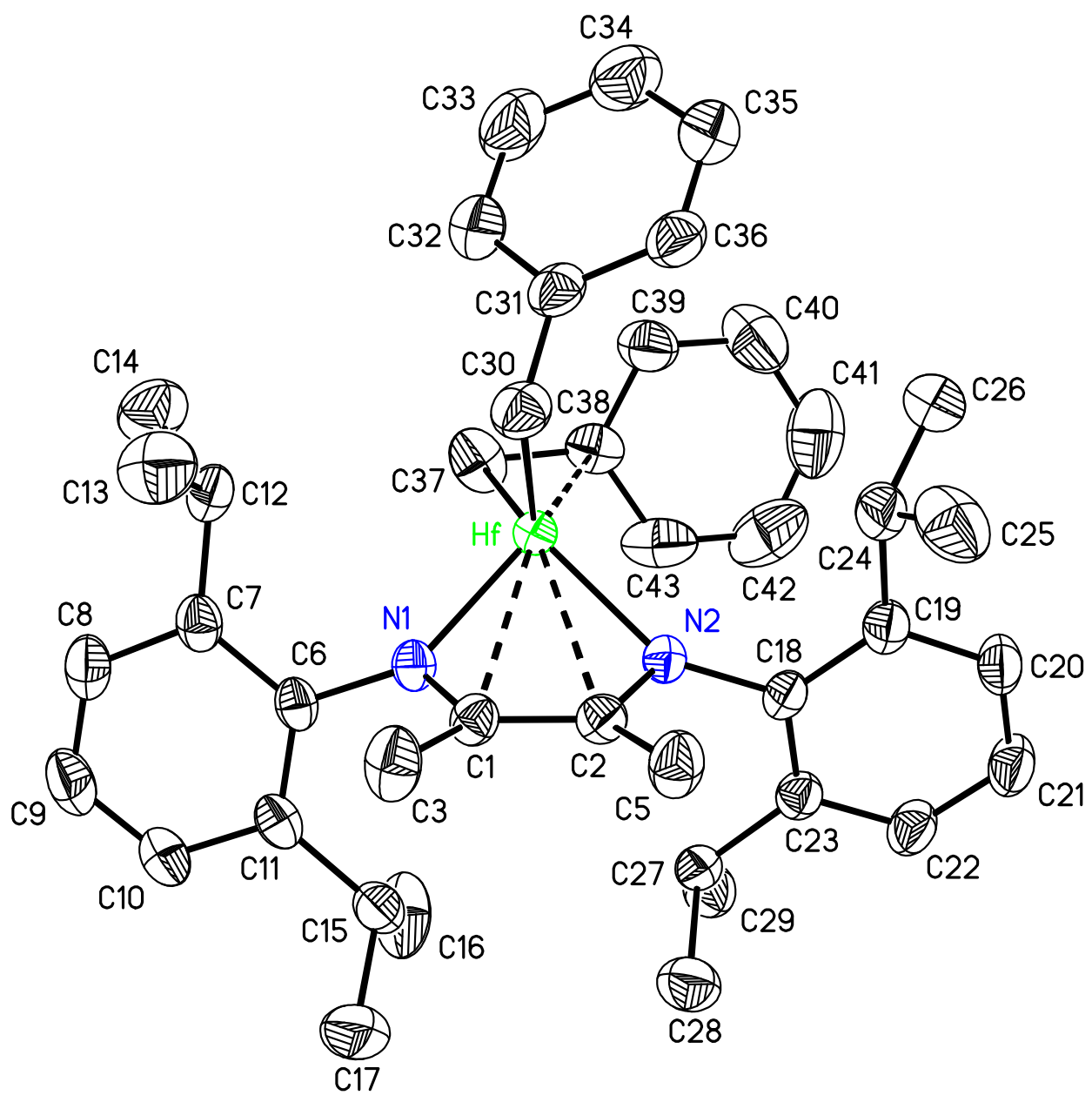

Figure 30. Molecular structure of 7 with full labeling scheme. Hydrogen atoms were removed for clarity. Thermal ellipsoids are shown at $40 \%$ probability. 


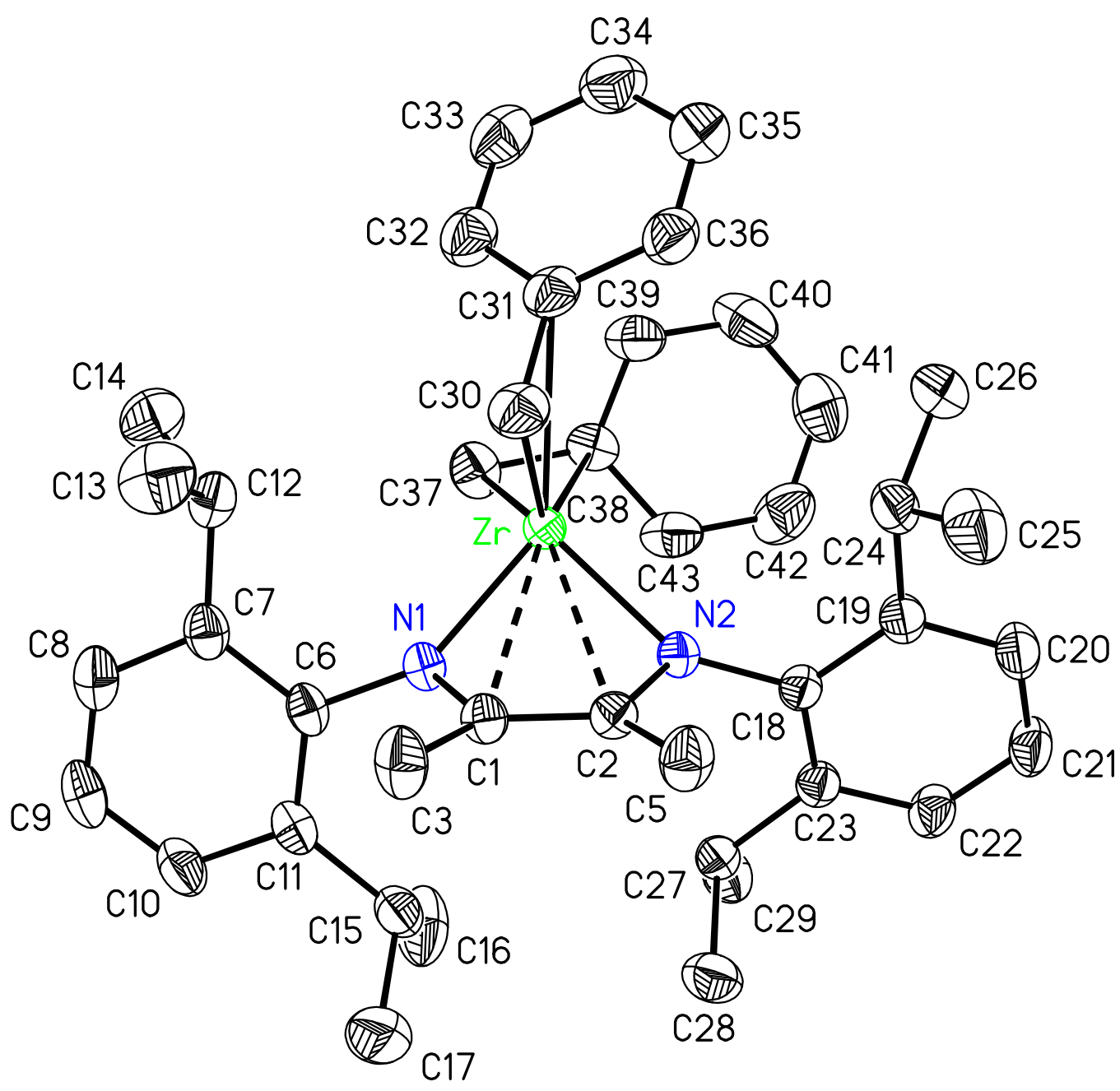

Figure 31. Molecular structure of $\mathbf{8}$ with full labeling scheme. Hydrogen atoms were removed for clarity. Thermal ellipsoids are shown at $40 \%$ probability. 


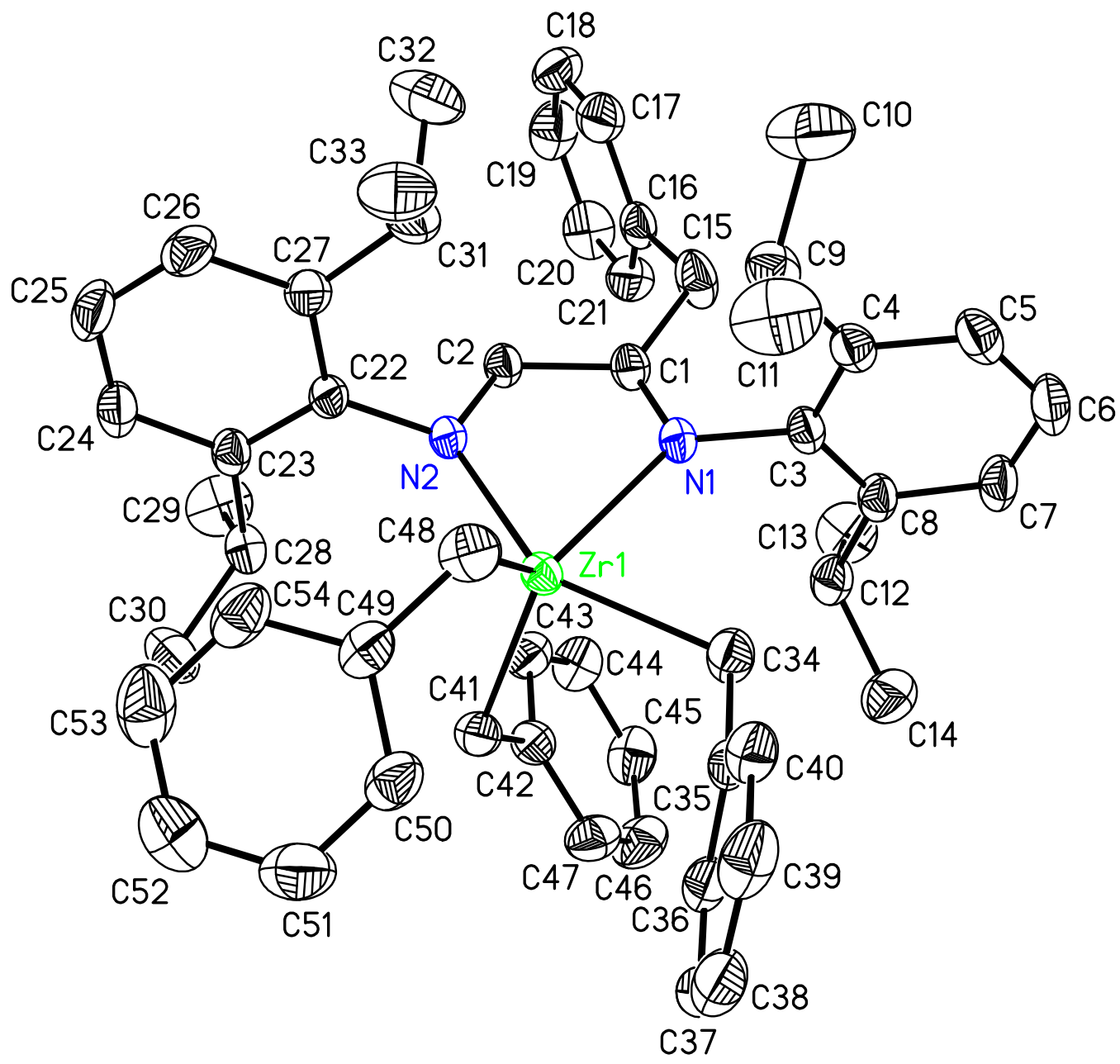

Figure 32. Molecular structure of $\mathbf{1 3}$ with full labeling scheme. Hydrogen atoms were removed for clarity. Thermal ellipsoids are shown at $40 \%$ probability. 
Table 4. Crystal data and structure refinement for 5 .

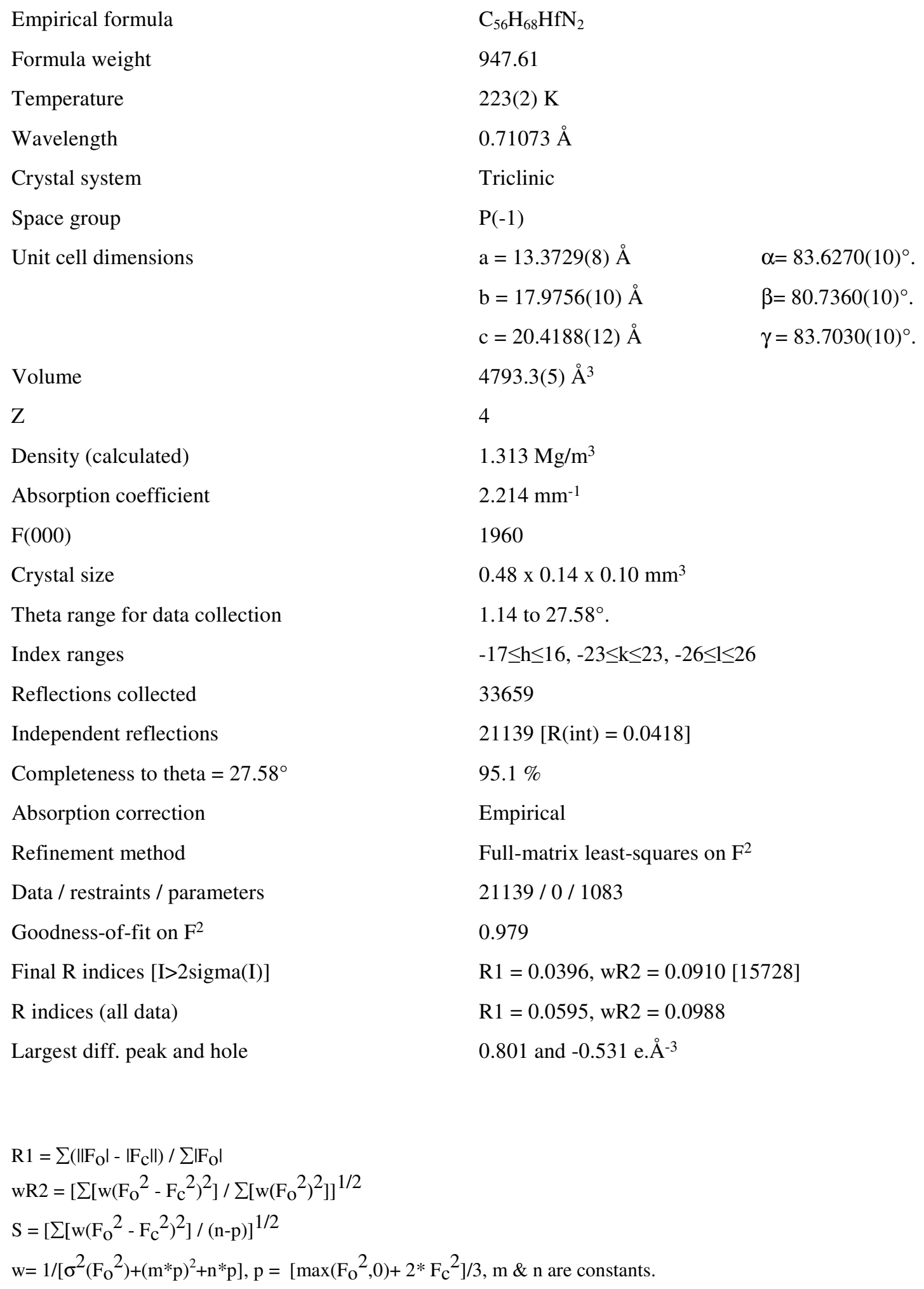


Table 5. Atomic coordinates ( $\left.\times 10^{4}\right)$ and equivalent isotropic displacement parameters $\left(\AA^{2} \times 10^{3}\right)$ for 5. $U(e q)$ is defined as one third of the trace of the orthogonalized $U^{i j}$ tensor.

\begin{tabular}{|c|c|c|c|c|}
\hline & $\mathrm{x}$ & $\mathrm{y}$ & $\mathrm{z}$ & $\mathrm{U}(\mathrm{eq})$ \\
\hline Hf & $3380(1)$ & $4637(1)$ & $7367(1)$ & $30(1)$ \\
\hline $\mathrm{Hf}^{\prime}$ & $1048(1)$ & $35(1)$ & $2524(1)$ & $29(1)$ \\
\hline N1 & $4252(2)$ & $4429(2)$ & $8130(2)$ & $29(1)$ \\
\hline $\mathrm{N} 2$ & $4386(2)$ & $3439(2)$ & $7263(2)$ & $32(1)$ \\
\hline N1' & $1629(2)$ & $962(2)$ & $1954(2)$ & $28(1)$ \\
\hline N2' & $-245(2)$ & $1095(2)$ & $2600(2)$ & $29(1)$ \\
\hline $\mathrm{C} 1$ & $5233(3)$ & $3930(2)$ & $8059(2)$ & $29(1)$ \\
\hline $\mathrm{C} 2$ & $5125(3)$ & $3337(2)$ & $7600(2)$ & $32(1)$ \\
\hline C3 & $6080(3)$ & $4439(2)$ & $7705(2)$ & $38(1)$ \\
\hline $\mathrm{C} 4$ & $5531(3)$ & $3553(2)$ & $8718(2)$ & $40(1)$ \\
\hline C5 & $5907(3)$ & $2662(2)$ & $7553(2)$ & $45(1)$ \\
\hline C6 & $3953(3)$ & $4741(2)$ & $8770(2)$ & $30(1)$ \\
\hline $\mathrm{C} 7$ & $4227(3)$ & $5443(2)$ & $8889(2)$ & $36(1)$ \\
\hline $\mathrm{C} 8$ & $3956(3)$ & $5680(3)$ & $9532(2)$ & $48(1)$ \\
\hline C9 & $3409(4)$ & $5256(3)$ & $10034(2)$ & $54(1)$ \\
\hline $\mathrm{C} 10$ & $3114(3)$ & $4582(3)$ & $9908(2)$ & $48(1)$ \\
\hline C11 & $3369(3)$ & $4313(2)$ & $9287(2)$ & $38(1)$ \\
\hline C12 & $4768(3)$ & $5999(2)$ & $8359(2)$ & $39(1)$ \\
\hline C13 & $5809(3)$ & $6128(2)$ & $8499(3)$ & $51(1)$ \\
\hline C14 & $4145(4)$ & $6774(2)$ & $8300(3)$ & $51(1)$ \\
\hline C15 & $2980(3)$ & $3583(2)$ & $9174(2)$ & $43(1)$ \\
\hline C16 & $2997(5)$ & 2983(3) & $9773(3)$ & $71(2)$ \\
\hline C17 & 1887(3) & $3728(3)$ & 8998(3) & $52(1)$ \\
\hline C18 & $4232(3)$ & 2893(2) & $6822(2)$ & $39(1)$ \\
\hline C19 & $4734(4)$ & $2926(2)$ & $6161(3)$ & $49(1)$ \\
\hline $\mathrm{C} 20$ & $4463(4)$ & $2446(3)$ & $5730(3)$ & $65(2)$ \\
\hline C21 & $3759(4)$ & $1942(3)$ & $5959(4)$ & $77(2)$ \\
\hline $\mathrm{C} 22$ & $3311(4)$ & 1891(3) & $6612(3)$ & $66(2)$ \\
\hline $\mathrm{C} 23$ & $3524(3)$ & $2364(2)$ & $7067(3)$ & $46(1)$ \\
\hline C24 & $5559(4)$ & $3443(3)$ & $5890(3)$ & $54(1)$ \\
\hline $\mathrm{C} 25$ & $6593(4)$ & $2986(3)$ & $5708(3)$ & $78(2)$ \\
\hline $\mathrm{C} 26$ & $5303(5)$ & $3960(3)$ & $5275(3)$ & $83(2)$ \\
\hline $\mathrm{C} 27$ & $3030(3)$ & $2278(2)$ & $7790(3)$ & $50(1)$ \\
\hline C28 & $3660(4)$ & $1690(3)$ & $8199(3)$ & $78(2)$ \\
\hline C29 & $1925(4)$ & 2068(3) & 7891(3) & $66(2)$ \\
\hline C30 & $2322(3)$ & $5610(2)$ & $7724(2)$ & $39(1)$ \\
\hline C31 & $4231(4)$ & $5240(2)$ & $6463(2)$ & $44(1)$ \\
\hline C32 & $2053(3)$ & $4083(2)$ & $7106(2)$ & $42(1)$ \\
\hline C33 & $7189(3)$ & $4144(2)$ & $7518(2)$ & $38(1)$ \\
\hline C34 & $7600(3)$ & $4066(2)$ & $6863(2)$ & $46(1)$ \\
\hline C35 & $8625(4)$ & $3872(2)$ & $6667(3)$ & $57(1)$ \\
\hline C36 & $9266(4)$ & $3742(2)$ & $7142(3)$ & $59(2)$ \\
\hline C37 & $8877(4)$ & $3820(2)$ & 7794(3) & $57(1)$ \\
\hline C38 & $7844(3)$ & $4025(2)$ & $7986(3)$ & $46(1)$ \\
\hline C39 & 1411(3) & $5644(2)$ & $8254(2)$ & $37(1)$ \\
\hline $\mathrm{C} 40$ & 1481(4) & $5833(3)$ & $8890(2)$ & $51(1)$ \\
\hline C41 & $642(4)$ & $5830(3)$ & $9386(3)$ & $68(2)$ \\
\hline $\mathrm{C} 42$ & $-276(4)$ & $5659(3)$ & $9266(3)$ & $66(2)$ \\
\hline $\mathrm{C} 43$ & $-369(4)$ & $5486(3)$ & $8642(3)$ & $58(1)$ \\
\hline $\mathrm{C} 44$ & $459(3)$ & $5481(2)$ & $8143(2)$ & $44(1)$ \\
\hline $\mathrm{C} 45$ & $4614(3)$ & $5985(2)$ & $6454(2)$ & $40(1)$ \\
\hline
\end{tabular}




\begin{tabular}{|c|c|c|c|c|}
\hline $\mathrm{C} 46$ & $5643(4)$ & $6073(3)$ & $6433(3)$ & $59(1)$ \\
\hline C47 & $5984(6)$ & $6781(4)$ & $6405(3)$ & $92(2)$ \\
\hline $\mathrm{C} 48$ & $5299(9)$ & 7411(4) & 6391(4) & $123(4)$ \\
\hline C49 & $4315(8)$ & $7332(3)$ & 6419(4) & $116(3)$ \\
\hline C50 & $3954(5)$ & $6639(3)$ & $6455(3)$ & $66(2)$ \\
\hline C51 & $1969(3)$ & $4334(2)$ & $6399(2)$ & $42(1)$ \\
\hline C52 & $2345(4)$ & $3879(3)$ & $5895(3)$ & $71(2)$ \\
\hline C53 & $2349(5)$ & $4131(4)$ & $5228(3)$ & $96(2)$ \\
\hline C54 & $1957(5)$ & $4845(4)$ & $5047(3)$ & $93(2)$ \\
\hline C55 & $1539(5)$ & $5302(4)$ & $5528(3)$ & $79(2)$ \\
\hline C56 & $1548(4)$ & $5064(3)$ & $6196(3)$ & $56(1)$ \\
\hline C1' & $1220(3)$ & $1751(2)$ & $2105(2)$ & $30(1)$ \\
\hline $\mathrm{C} 2{ }^{\prime}$ & $87(3)$ & $1736(2)$ & $2398(2)$ & $31(1)$ \\
\hline C3' & $1806(3)$ & $1968(2)$ & $2650(2)$ & $36(1)$ \\
\hline C4' & $1360(3)$ & $2330(2)$ & $1487(2)$ & $38(1)$ \\
\hline C5' & $-557(3)$ & $2474(2)$ & $2438(2)$ & $44(1)$ \\
\hline C6' & $2407(3)$ & $890(2)$ & $1375(2)$ & $31(1)$ \\
\hline C7' & $3461(3)$ & $829(2)$ & $1425(2)$ & $35(1)$ \\
\hline C8' & $4157(3)$ & $783(2)$ & $843(2)$ & $47(1)$ \\
\hline C9' & $3867(4)$ & $772(2)$ & 227(3) & $53(1)$ \\
\hline C10' & 2834(3) & $804(2)$ & $188(2)$ & $45(1)$ \\
\hline C11' & 2104(3) & $864(2)$ & $746(2)$ & $36(1)$ \\
\hline C12' & $3887(3)$ & $806(2)$ & $2073(2)$ & $37(1)$ \\
\hline C13' & $4462(3)$ & $1493(2)$ & 2084(3) & $56(1)$ \\
\hline C14' & $4616(3)$ & $97(2)$ & 2183(3) & $51(1)$ \\
\hline C15' & $991(3)$ & $858(2)$ & $671(2)$ & $37(1)$ \\
\hline C16' & $694(4)$ & $1333(2)$ & $53(2)$ & $54(1)$ \\
\hline $\mathrm{C} 17^{\prime}$ & $742(3)$ & $38(2)$ & $689(2)$ & $45(1)$ \\
\hline C18' & $-1308(3)$ & $1048(2)$ & 2882(2) & $34(1)$ \\
\hline C19' & $-1641(3)$ & $1118(2)$ & $3557(2)$ & $38(1)$ \\
\hline C20' & $-2639(3)$ & $958(2)$ & $3820(3)$ & $50(1)$ \\
\hline $\mathrm{C} 21^{\prime}$ & $-3281(3)$ & $756(3)$ & $3426(3)$ & $57(1)$ \\
\hline C22' & $-2960(3)$ & $730(2)$ & $2748(3)$ & $51(1)$ \\
\hline C23' & $-1976(3)$ & $872(2)$ & $2455(2)$ & $39(1)$ \\
\hline C24' & $-996(3)$ & $1364(2)$ & $4027(2)$ & $45(1)$ \\
\hline C25' & $-1420(4)$ & $2137(3)$ & $4266(3)$ & $65(2)$ \\
\hline C26' & $-892(4)$ & $791(3)$ & $4635(3)$ & $62(1)$ \\
\hline C27' & $-1679(3)$ & $879(2)$ & $1709(2)$ & $43(1)$ \\
\hline C28' & $-1912(5)$ & $1667(3)$ & 1355(3) & $75(2)$ \\
\hline C29' & $-2165(4)$ & $314(3)$ & $1385(3)$ & $63(1)$ \\
\hline C30' & $2205(3)$ & $-891(2)$ & $2171(2)$ & $41(1)$ \\
\hline C31' & $1330(3)$ & $-5(2)$ & $3577(2)$ & $42(1)$ \\
\hline C32' & $-222(3)$ & $-686(2)$ & $2462(2)$ & $44(1)$ \\
\hline C33' & $1532(3)$ & $2701(2)$ & 2973(2) & $34(1)$ \\
\hline C34' & $1081(3)$ & $2697(2)$ & $3632(2)$ & $45(1)$ \\
\hline C $35^{\prime}$ & $853(4)$ & $3354(2)$ & $3939(3)$ & $57(1)$ \\
\hline C36' & $1051(4)$ & $4031(2)$ & $3585(3)$ & $57(1)$ \\
\hline C37' & $1504(4)$ & $4052(2)$ & $2949(3)$ & $53(1)$ \\
\hline C38' & $1743(3)$ & $3394(2)$ & $2629(2)$ & $43(1)$ \\
\hline C39' & $2408(3)$ & $-1290(2)$ & $1555(2)$ & $38(1)$ \\
\hline C40' & $3143(4)$ & $-1088(3)$ & 1026(3) & $58(1)$ \\
\hline C41' & $3303(5)$ & $-1451(3)$ & $452(3)$ & $68(2)$ \\
\hline C42' & $2763(5)$ & $-2026(3)$ & $378(3)$ & $66(2)$ \\
\hline C43' & 2033(4) & $-2235(3)$ & $897(3)$ & $60(1)$ \\
\hline C44' & $1845(4)$ & $-1885(2)$ & 1481(3) & $48(1)$ \\
\hline C45' & $2333(3)$ & $-49(2)$ & $3792(2)$ & $41(1)$ \\
\hline
\end{tabular}




\begin{tabular}{lrrrr} 
C46' & $2729(5)$ & $549(3)$ & $4007(3)$ & $74(2)$ \\
C47' & $3738(5)$ & $448(4)$ & $4218(3)$ & $78(2)$ \\
C48' & $4252(5)$ & $-243(4)$ & $4191(4)$ & $87(2)$ \\
C49' & $3876(5)$ & $-837(4)$ & $3993(4)$ & $100(2)$ \\
C50' & $2939(4)$ & $-729(3)$ & $3794(3)$ & $69(2)$ \\
C51' & $-466(3)$ & $-1105(2)$ & $3123(2)$ & $42(1)$ \\
C52' & $-1220(3)$ & $-829(2)$ & $3614(3)$ & $50(1)$ \\
C53' & $-1417(4)$ & $-1176(3)$ & $4241(3)$ & $65(1)$ \\
C54' & $-871(5)$ & $-1829(3)$ & $4419(3)$ & $77(2)$ \\
C55' & $-122(5)$ & $-2125(3)$ & $3955(3)$ & $78(2)$ \\
C56' & $89(4)$ & $-1777(2)$ & $3317(3)$ & $59(1)$ \\
\hline
\end{tabular}

Table 6. Bond lengths $[\AA]$ and angles $\left[{ }^{\circ}\right]$ for $\mathbf{5}$.

\begin{tabular}{|c|c|c|c|}
\hline Hf-N1 & $2.070(3)$ & $\mathrm{C} 18-\mathrm{C} 23$ & $1.411(6)$ \\
\hline Hf-C30 & $2.237(3)$ & C19-C20 & $1.410(7)$ \\
\hline Hf-C31 & $2.242(5)$ & C19-C24 & $1.517(7)$ \\
\hline Hf-C32 & $2.288(4)$ & C20-C21 & $1.370(8)$ \\
\hline Hf-N2 & $2.423(3)$ & $\mathrm{C} 21-\mathrm{C} 22$ & $1.370(9)$ \\
\hline Hf'-N1' & $2.073(3)$ & C22-C23 & $1.407(7)$ \\
\hline Hf'-C31' & $2.235(4)$ & C23-C27 & $1.515(7)$ \\
\hline Hf'-C30' & $2.241(3)$ & C24-C26 & $1.540(7)$ \\
\hline $\mathrm{Hf}^{\prime}-\mathrm{C} 32^{\prime}$ & $2.273(4)$ & C24-C25 & $1.543(6)$ \\
\hline Hf'-N2' & $2.431(3)$ & C27-C28 & $1.537(6)$ \\
\hline N1-C6 & $1.458(5)$ & C27-C29 & $1.541(6)$ \\
\hline N1-C1 & $1.503(4)$ & C30-C39 & $1.494(6)$ \\
\hline $\mathrm{N} 2-\mathrm{C} 2$ & $1.278(5)$ & C31-C45 & $1.482(6)$ \\
\hline N2-C18 & $1.455(5)$ & C32-C51 & $1.483(6)$ \\
\hline N1'-C6' & $1.451(5)$ & C33-C34 & $1.378(6)$ \\
\hline N1'-C1' & $1.508(4)$ & C33-C38 & $1.381(6)$ \\
\hline N2'-C2' & $1.281(5)$ & C34-C35 & $1.382(6)$ \\
\hline N2'-C18' & $1.452(5)$ & C35-C36 & $1.379(7)$ \\
\hline $\mathrm{C} 1-\mathrm{C} 2$ & $1.527(5)$ & C36-C37 & $1.366(8)$ \\
\hline C1-C4 & $1.528(5)$ & C37-C38 & $1.394(6)$ \\
\hline C1-C3 & $1.568(5)$ & C39-C44 & $1.396(6)$ \\
\hline C2-C5 & $1.513(4)$ & C39-C40 & $1.397(6)$ \\
\hline C3-C33 & $1.522(5)$ & C40-C41 & $1.385(7)$ \\
\hline C6-C7 & $1.410(5)$ & $\mathrm{C} 41-\mathrm{C} 42$ & $1.363(8)$ \\
\hline C6-C11 & $1.415(6)$ & $\mathrm{C} 42-\mathrm{C} 43$ & $1.372(8)$ \\
\hline C7-C8 & $1.404(6)$ & C43-C44 & $1.379(6)$ \\
\hline C7-C12 & $1.535(6)$ & C45-C50 & $1.390(5)$ \\
\hline C8-C9 & $1.369(7)$ & C45-C46 & $1.395(6)$ \\
\hline C9-C10 & $1.376(7)$ & C46-C47 & $1.391(8)$ \\
\hline C10-C11 & $1.386(6)$ & C47-C48 & $1.378(10)$ \\
\hline C11-C15 & $1.518(6)$ & C48-C49 & $1.331(12)$ \\
\hline C12-C13 & $1.513(6)$ & C49-C50 & $1.375(10)$ \\
\hline C12-C14 & $1.546(5)$ & C51-C52 & $1.382(7)$ \\
\hline C15-C16 & $1.540(6)$ & C51-C56 & $1.414(6)$ \\
\hline C15-C17 & $1.548(6)$ & C52-C53 & $1.387(8)$ \\
\hline C18-C19 & $1.406(6)$ & C53-C54 & $1.367(8)$ \\
\hline
\end{tabular}




\begin{tabular}{|c|c|}
\hline C54-C55 & $1.362(8)$ \\
\hline C55-C56 & $1.385(8)$ \\
\hline C1'-C2' & $1.538(5)$ \\
\hline C1'-C4' & $1.544(5)$ \\
\hline C1'-C3' & $1.566(5)$ \\
\hline C2'-C5' & $1.504(4)$ \\
\hline C3'-C33' & $1.522(5)$ \\
\hline C6'-C11' & $1.415(6)$ \\
\hline C6'-C7' & $1.421(5)$ \\
\hline C7'-C8' & $1.392(6)$ \\
\hline C7'-C12' & $1.518(6)$ \\
\hline C8'-C9' & $1.376(7)$ \\
\hline C9'-C10' & $1.391(6)$ \\
\hline C10'-C11' & $1.381(6)$ \\
\hline C11'-C15' & $1.522(6)$ \\
\hline C12'-C13' & $1.528(6)$ \\
\hline C12'-C14' & $1.536(5)$ \\
\hline C15'-C16' & $1.525(6)$ \\
\hline C15'-C17' & $1.542(6)$ \\
\hline C18'-C19' & $1.394(6)$ \\
\hline C18'-C23' & $1.426(6)$ \\
\hline C19'-C20' & $1.405(6)$ \\
\hline C19'-C24' & $1.520(6)$ \\
\hline C20'-C21' & $1.367(7)$ \\
\hline C21'-C22' & $1.386(7)$ \\
\hline C22'-C23' & $1.393(6)$ \\
\hline C23'-C27' & $1.510(6)$ \\
\hline C24'-C26' & $1.536(7)$ \\
\hline C24'-C25' & $1.541(6)$ \\
\hline C27'-C29' & $1.524(6)$ \\
\hline C27'-C28' & $1.542(6)$ \\
\hline C30'-C39' & $1.489(6)$ \\
\hline C31'-C45' & $1.468(6)$ \\
\hline C32'-C51' & $1.478(6)$ \\
\hline C33'-C34' & $1.383(6)$ \\
\hline C33'-C38' & $1.392(6)$ \\
\hline C34'-C35' & $1.381(6)$ \\
\hline C35'-C36' & $1.372(7)$ \\
\hline C36'-C37' & $1.341(7)$ \\
\hline C37'-C38' & $1.396(6)$ \\
\hline C39'-C40' & $1.383(6)$ \\
\hline C39'-C44' & $1.408(6)$ \\
\hline C40'-C41' & $1.380(8)$ \\
\hline C41'-C42' & $1.359(8)$ \\
\hline C42'-C43' & $1.370(8)$ \\
\hline C43'-C44' & $1.384(7)$ \\
\hline C45'-C50' & $1.391(6)$ \\
\hline C45'-C46' & $1.391(7)$ \\
\hline C46'-C47' & $1.467(8)$ \\
\hline C47'-C48' & $1.353(8)$ \\
\hline C48'-C49' & $1.355(10)$ \\
\hline C49'-C50' & $1.366(8)$ \\
\hline C51'-C52' & $1.394(6)$ \\
\hline C51'-C56' & $1.400(5)$ \\
\hline C52'-C53' & $1.359(7)$ \\
\hline C53'-C54' & $1.358(7)$ \\
\hline
\end{tabular}

\begin{tabular}{|c|c|}
\hline C54'-C55' & $1.369(8)$ \\
\hline C55'-C56' & $1.380(8)$ \\
\hline N1-Hf-C30 & $100.37(14)$ \\
\hline N1-Hf-C31 & $110.95(15)$ \\
\hline C30-Hf-C31 & $98.34(15)$ \\
\hline N1-Hf-C32 & $133.75(14)$ \\
\hline C30-Hf-C32 & $90.84(15)$ \\
\hline C31-Hf-C32 & $111.52(17)$ \\
\hline N1-Hf-N2 & 70.81(11) \\
\hline C30-Hf-N2 & $165.38(14)$ \\
\hline C31-Hf-N2 & $95.77(13)$ \\
\hline C32-Hf-N2 & $87.52(12)$ \\
\hline N1'-Hf'-C31' & $110.98(15)$ \\
\hline N1'-Hf'-C30' & $101.09(14)$ \\
\hline C31'-Hf'-C30' & $99.52(15)$ \\
\hline N1'-Hf'-C32' & $134.56(14)$ \\
\hline C31'-Hf'-C32' & $110.33(17)$ \\
\hline C30'-Hf'-C32' & $89.98(15)$ \\
\hline N1'-Hf'-N2' & $71.18(11)$ \\
\hline C31'-Hf'-N2' & $95.22(13)$ \\
\hline C30'-Hf'-N2' & $165.08(14)$ \\
\hline C32'-Hf'-N2' & $87.06(12)$ \\
\hline C6-N1-C1 & $115.7(3)$ \\
\hline C6-N1-Hf & $122.8(2)$ \\
\hline C1-N1-Hf & $121.5(2)$ \\
\hline C2-N2-C18 & $121.4(3)$ \\
\hline C2-N2-Hf & $114.3(2)$ \\
\hline C18-N2-Hf & $124.2(2)$ \\
\hline C6'-N1'-C1' & $116.7(3)$ \\
\hline C6'-N1'-Hf' & $122.1(2)$ \\
\hline C1'-N1'-Hf' & $121.1(2)$ \\
\hline C2'-N2'-C18' & $120.3(3)$ \\
\hline C2'-N2'-Hf' & $114.6(2)$ \\
\hline C18'-N2'-Hf' & $125.1(2)$ \\
\hline $\mathrm{N} 1-\mathrm{C} 1-\mathrm{C} 2$ & $107.2(3)$ \\
\hline $\mathrm{N} 1-\mathrm{C} 1-\mathrm{C} 4$ & $114.4(3)$ \\
\hline $\mathrm{C} 2-\mathrm{C} 1-\mathrm{C} 4$ & $110.3(3)$ \\
\hline $\mathrm{N} 1-\mathrm{C} 1-\mathrm{C} 3$ & $106.4(3)$ \\
\hline $\mathrm{C} 2-\mathrm{C} 1-\mathrm{C} 3$ & $108.8(3)$ \\
\hline $\mathrm{C} 4-\mathrm{C} 1-\mathrm{C} 3$ & $109.4(3)$ \\
\hline N2-C2-C5 & $122.7(4)$ \\
\hline $\mathrm{N} 2-\mathrm{C} 2-\mathrm{C} 1$ & $118.5(3)$ \\
\hline $\mathrm{C} 5-\mathrm{C} 2-\mathrm{C} 1$ & $118.8(3)$ \\
\hline C33-C3-C1 & $123.4(3)$ \\
\hline C7-C6-C11 & $119.4(4)$ \\
\hline C7-C6-N1 & $122.5(4)$ \\
\hline C11-C6-N1 & 118.1(3) \\
\hline C8-C7-C6 & $118.6(4)$ \\
\hline C8-C7-C12 & $116.3(4)$ \\
\hline C6-C7-C12 & $125.1(4)$ \\
\hline C9-C8-C7 & $121.6(4)$ \\
\hline C8-C9-C10 & $119.5(4)$ \\
\hline C9-C10-C11 & $121.7(4)$ \\
\hline C10-C11-C6 & 119.1(4) \\
\hline C10-C11-C15 & $119.0(4)$ \\
\hline
\end{tabular}




\begin{tabular}{|c|c|}
\hline C6-C11-C15 & $121.8(4)$ \\
\hline $\mathrm{C} 13-\mathrm{C} 12-\mathrm{C} 7$ & 112.7(3) \\
\hline C13-C12-C14 & $107.5(3)$ \\
\hline C7-C12-C14 & $112.0(3)$ \\
\hline C11-C15-C16 & 113.3(4) \\
\hline C11-C15-C17 & 110.6(3) \\
\hline C16-C15-C17 & 109.4(4) \\
\hline C19-C18-C23 & $121.5(4)$ \\
\hline C19-C18-N2 & $120.4(4)$ \\
\hline C23-C18-N2 & $118.0(4)$ \\
\hline C18-C19-C20 & $118.2(5)$ \\
\hline C18-C19-C24 & $123.4(4)$ \\
\hline C20-C19-C24 & $118.4(5)$ \\
\hline C21-C20-C19 & $120.7(6)$ \\
\hline $\mathrm{C} 22-\mathrm{C} 21-\mathrm{C} 20$ & $120.5(5)$ \\
\hline $\mathrm{C} 21-\mathrm{C} 22-\mathrm{C} 23$ & $122.0(5)$ \\
\hline C22-C23-C18 & $117.0(5)$ \\
\hline C22-C23-C27 & $120.3(5)$ \\
\hline C18-C23-C27 & $122.6(4)$ \\
\hline C19-C24-C26 & $112.1(5)$ \\
\hline C19-C24-C25 & $110.9(4)$ \\
\hline C26-C24-C25 & $109.2(5)$ \\
\hline C23-C27-C28 & $110.8(4)$ \\
\hline C23-C27-C29 & 114.2(4) \\
\hline C28-C27-C29 & $108.9(4)$ \\
\hline C39-C30-Hf & 131.2(3) \\
\hline $\mathrm{C} 45-\mathrm{C} 31-\mathrm{Hf}$ & $124.2(3)$ \\
\hline C51-C32-Hf & 107.1(3) \\
\hline C34-C33-C38 & $117.5(4)$ \\
\hline C34-C33-C3 & $120.8(4)$ \\
\hline C38-C33-C3 & $121.3(4)$ \\
\hline C33-C34-C35 & $122.4(5)$ \\
\hline C36-C35-C34 & 119.3(5) \\
\hline C37-C36-C35 & 119.3(4) \\
\hline C36-C37-C38 & $121.0(5)$ \\
\hline C33-C38-C37 & $120.4(5)$ \\
\hline C44-C39-C40 & $116.9(4)$ \\
\hline C44-C39-C30 & 121.9(4) \\
\hline C40-C39-C30 & 121.1(4) \\
\hline C41-C40-C39 & $120.6(5)$ \\
\hline C42-C41-C40 & $121.2(5)$ \\
\hline C41-C42-C43 & $119.3(5)$ \\
\hline C42-C43-C44 & $120.3(5)$ \\
\hline C43-C44-C39 & $121.6(5)$ \\
\hline C50-C45-C46 & $116.6(5)$ \\
\hline C50-C45-C31 & $120.9(4)$ \\
\hline C46-C45-C31 & $122.6(4)$ \\
\hline C47-C46-C45 & 121.3(5) \\
\hline C48-C47-C46 & $119.8(7)$ \\
\hline C49-C48-C47 & $119.3(7)$ \\
\hline C48-C49-C50 & $122.3(7)$ \\
\hline C49-C50-C45 & $120.8(6)$ \\
\hline C52-C51-C56 & 116.1(5) \\
\hline C52-C51-C32 & $121.7(4)$ \\
\hline C56-C51-C32 & $122.1(4)$ \\
\hline C51-C52-C53 & $122.1(5)$ \\
\hline
\end{tabular}

\begin{tabular}{|c|c|}
\hline C54-C53-C52 & $120.3(6)$ \\
\hline C55-C54-C53 & $119.6(6)$ \\
\hline C54-C55-C56 & $120.7(5)$ \\
\hline C55-C56-C51 & $121.1(5)$ \\
\hline N1'-C1'-C2' & 107.7(3) \\
\hline N1'-C1'-C4' & $113.0(3)$ \\
\hline $\mathrm{C} 2{ }^{\prime}-\mathrm{C} 1{ }^{\prime}-\mathrm{C} 4{ }^{\prime}$ & $110.7(3)$ \\
\hline N1'-C1'-C3' & 107.1(3) \\
\hline $\mathrm{C} 2{ }^{\prime}-\mathrm{C} 1{ }^{\prime}-\mathrm{C} 3{ }^{\prime}$ & $108.7(3)$ \\
\hline C4'-C1'-C3' & 109.4(3) \\
\hline N2'-C2'-C5' & 124.1(4) \\
\hline $\mathrm{N} 2{ }^{\prime}-\mathrm{C} 2{ }^{\prime}-\mathrm{C} 1 '$ & 117.9(3) \\
\hline $\mathrm{C} 55^{\prime}-\mathrm{C} 2^{\prime}-\mathrm{C} 1^{\prime}$ & $118.0(3)$ \\
\hline C33'-C3'-C1' & 122.1(3) \\
\hline C11'-C6'-C7' & 119.3(4) \\
\hline C11'-C6'-N1' & $118.9(3)$ \\
\hline C7'-C6'-N1' & $121.9(4)$ \\
\hline C8'-C7'-C6' & 118.2(4) \\
\hline C8'-C7'-C12' & $117.2(4)$ \\
\hline C6'-C7'-C12' & $124.5(4)$ \\
\hline C9'-C8'-C7' & $122.8(4)$ \\
\hline C8'-C9'-C10' & $118.5(4)$ \\
\hline $\mathrm{C} 11^{\prime}-\mathrm{C} 10^{\prime}-\mathrm{C} 9^{\prime}$ & 121.6(4) \\
\hline $\mathrm{C} 10^{\prime}-\mathrm{C} 11^{\prime}-\mathrm{C} 6{ }^{\prime}$ & $119.6(4)$ \\
\hline $\mathrm{C} 10^{\prime}-\mathrm{C} 11^{\prime}-\mathrm{C} 15^{\prime}$ & 118.7(4) \\
\hline C6'-C11'-C15' & $121.6(4)$ \\
\hline C7'-C12'-C13' & 111.1(4) \\
\hline C7'-C12'-C14' & $111.7(3)$ \\
\hline C13'-C12'-C14' & $108.3(3)$ \\
\hline C11'-C15'-C16' & $113.8(4)$ \\
\hline $\mathrm{C} 11^{\prime}-\mathrm{C} 15^{\prime}-\mathrm{C} 17^{\prime}$ & 109.2(3) \\
\hline $\mathrm{C} 16^{\prime}-\mathrm{C} 15^{\prime}-\mathrm{C} 17^{\prime}$ & $111.5(4)$ \\
\hline C19'-C18'-C23' & $121.4(4)$ \\
\hline C19'-C18'-N2' & $120.9(4)$ \\
\hline C23'-C18'-N2' & 117.6(4) \\
\hline C18'-C19'-C20' & $118.2(4)$ \\
\hline C18'-C19'-C24' & $124.2(4)$ \\
\hline $\mathrm{C} 20^{\prime}-\mathrm{C} 19^{\prime}-\mathrm{C} 24^{\prime}$ & 117.6(4) \\
\hline $\mathrm{C} 21^{\prime}-\mathrm{C} 20^{\prime}-\mathrm{C} 19^{\prime}$ & $121.3(5)$ \\
\hline $\mathrm{C} 20^{\prime}-\mathrm{C} 21^{\prime}-\mathrm{C} 22^{\prime}$ & $119.9(5)$ \\
\hline C21'-C22'-C23' & $121.8(5)$ \\
\hline $\mathrm{C} 22^{\prime}-\mathrm{C} 23^{\prime}-\mathrm{C} 18^{\prime}$ & 117.2(4) \\
\hline $\mathrm{C} 22^{\prime}-\mathrm{C} 23^{\prime}-\mathrm{C} 27^{\prime}$ & $119.8(4)$ \\
\hline $\mathrm{C} 18^{\prime}-\mathrm{C} 23^{\prime}-\mathrm{C} 27^{\prime}$ & $122.9(4)$ \\
\hline $\mathrm{C} 19^{\prime}-\mathrm{C} 24^{\prime}-\mathrm{C} 26^{\prime}$ & 112.9(4) \\
\hline $\mathrm{C} 19^{\prime}-\mathrm{C} 24^{\prime}-\mathrm{C} 25^{\prime}$ & $111.3(4)$ \\
\hline $\mathrm{C} 26^{\prime}-\mathrm{C} 24^{\prime}-\mathrm{C} 25^{\prime}$ & $109.4(4)$ \\
\hline C23'-C27'-C29' & $115.2(4)$ \\
\hline $\mathrm{C} 23^{\prime}-\mathrm{C} 27^{\prime}-\mathrm{C} 28^{\prime}$ & $111.2(4)$ \\
\hline $\mathrm{C} 29^{\prime}-\mathrm{C} 27^{\prime}-\mathrm{C} 28^{\prime}$ & 108.4(4) \\
\hline C39'-C30'-Hf' & $133.4(3)$ \\
\hline C45'-C $31^{\prime}-\mathrm{Hf}^{\prime}$ & $125.6(3)$ \\
\hline C51'-C32'-Hf' & 107.3(3) \\
\hline C34'-C33'-C $38^{\prime}$ & $117.6(4)$ \\
\hline C34'-C33'-C3' & $120.3(4)$ \\
\hline C38'-C33'-C3' & 122.1(4) \\
\hline
\end{tabular}




$\begin{array}{ll}\text { C35'-C34'-C33' } & 121.2(4) \\ \text { C36'-C35'-C34' } & 120.1(5) \\ \text { C37'-C36'-C35' } & 120.1(4) \\ \text { C36'-C37'-C38' } & 120.7(4) \\ \text { C33'-C38'-C37' } & 120.3(4) \\ \text { C40'-C39'-C44' } & 116.9(4) \\ \text { C40'-C39'-C30' } & 121.8(4) \\ \text { C44'-C39'-C30' } & 121.3(4) \\ \text { C41'-C40'-C39' } & 121.1(5) \\ \text { C42'-C41'-C40' } & 122.3(6) \\ \text { C41'-C42'-C43' } & 117.5(5) \\ \text { C42'-C43'-C44' } & 122.1(5) \\ \text { C43'-C44'-C39' } & 120.2(5) \\ \text { C50'-C45'-C46' } & 116.4(5) \\ \text { C50'-C45'-C31' } & 119.2(5) \\ \text { C46'-C45'-C31' } & 124.4(4) \\ \text { C45'-C46'-C47' } & 120.4(5) \\ \text { C48'-C47'-C46' } & 117.2(6) \\ \text { C47'-C48'-C49' } & 123.5(7) \\ \text { C48'-C49'-C50' } & 118.3(6) \\ \text { C49'-C50'-C45' } & 124.2(6) \\ \text { C52'-C51'-C56' } & 115.3(5) \\ \text { C52'-C51'-C32' } & 122.1(4) \\ \text { C56'-C51'-C32' } & 122.5(4) \\ \text { C53'-C52'-C51' } & 123.5(4) \\ \text { C54'-C53'-C52' } & 120.3(5) \\ \text { C53'-C54'-C55' } & 118.5(6) \\ \text { C54'-C55'-C56' } & 121.8(5) \\ \text { C55'-C56'-C51' } & 120.6(5)\end{array}$


Table 7. Anisotropic displacement parameters $\left(\AA^{2} \mathrm{x} 10^{3}\right)$ for 5. The anisotropic displacement factor exponent takes the form: $-2 \pi^{2}\left[h^{2} a^{* 2} U^{11}+\ldots+2 h k a^{*} b^{*} U^{12}\right]$

\begin{tabular}{|c|c|c|c|c|c|c|}
\hline & $\mathrm{U}^{11}$ & $\mathrm{U}^{22}$ & $\mathrm{U}^{33}$ & $\mathrm{U}^{23}$ & $\mathrm{U}^{13}$ & $\mathrm{U}^{12}$ \\
\hline $\mathrm{Hf}$ & $28(1)$ & $34(1)$ & $28(1)$ & $-2(1)$ & $-5(1)$ & $-3(1)$ \\
\hline $\mathrm{Hf}^{\prime}$ & $27(1)$ & $27(1)$ & $34(1)$ & 1(1) & $-4(1)$ & $-5(1)$ \\
\hline N1 & $26(2)$ & $33(2)$ & $28(2)$ & $-4(1)$ & $-5(1)$ & $-2(1)$ \\
\hline N2 & $32(2)$ & $31(2)$ & $33(2)$ & $-6(1)$ & $-2(2)$ & $-5(1)$ \\
\hline N1' & $28(2)$ & $26(1)$ & $30(2)$ & $-4(1)$ & $-4(1)$ & $-6(1)$ \\
\hline N2' & $21(2)$ & $35(2)$ & $33(2)$ & $-2(1)$ & $-5(1)$ & $-4(1)$ \\
\hline $\mathrm{C} 1$ & $26(2)$ & $30(2)$ & $32(2)$ & $-2(2)$ & $-7(2)$ & $-4(1)$ \\
\hline $\mathrm{C} 2$ & $26(2)$ & $32(2)$ & $38(2)$ & $0(2)$ & $-5(2)$ & $-3(1)$ \\
\hline C3 & $32(2)$ & $35(2)$ & $45(3)$ & $-2(2)$ & $-2(2)$ & $-3(2)$ \\
\hline $\mathrm{C} 4$ & $38(2)$ & $48(2)$ & $34(2)$ & $4(2)$ & $-8(2)$ & $-6(2)$ \\
\hline C5 & $41(2)$ & $35(2)$ & $60(3)$ & $-3(2)$ & $-12(2)$ & $4(2)$ \\
\hline C6 & $27(2)$ & $36(2)$ & $27(2)$ & $-3(2)$ & $-3(2)$ & $-4(1)$ \\
\hline C7 & $33(2)$ & $40(2)$ & $35(2)$ & $-5(2)$ & $-10(2)$ & $-5(2)$ \\
\hline C8 & $51(3)$ & $58(3)$ & $39(3)$ & $-21(2)$ & $-10(2)$ & $-7(2)$ \\
\hline C9 & $54(3)$ & $81(3)$ & $28(2)$ & $-17(2)$ & $0(2)$ & $-15(2)$ \\
\hline C10 & 48(3) & $69(3)$ & $24(2)$ & $-4(2)$ & $3(2)$ & $-11(2)$ \\
\hline $\mathrm{C} 11$ & $31(2)$ & $46(2)$ & $36(2)$ & $2(2)$ & $-8(2)$ & $-7(2)$ \\
\hline $\mathrm{C} 12$ & $42(2)$ & $38(2)$ & $37(2)$ & $-5(2)$ & $-2(2)$ & $-10(2)$ \\
\hline $\mathrm{C} 13$ & $47(3)$ & $51(2)$ & $59(3)$ & $-8(2)$ & $-7(2)$ & $-16(2)$ \\
\hline C14 & $56(3)$ & $37(2)$ & $63(3)$ & $-8(2)$ & $-12(3)$ & $-7(2)$ \\
\hline $\mathrm{C} 15$ & $42(2)$ & $45(2)$ & $39(3)$ & $5(2)$ & $3(2)$ & $-17(2)$ \\
\hline C16 & $90(4)$ & $57(3)$ & $63(4)$ & $22(3)$ & $-11(3)$ & $-23(3)$ \\
\hline C17 & $46(3)$ & $57(3)$ & $55(3)$ & $-11(2)$ & $0(2)$ & $-17(2)$ \\
\hline C18 & $39(2)$ & $37(2)$ & $43(3)$ & $-12(2)$ & $-11(2)$ & $-1(2)$ \\
\hline C19 & $49(3)$ & $47(2)$ & $52(3)$ & $-19(2)$ & $-7(2)$ & $-1(2)$ \\
\hline C20 & $60(3)$ & $78(3)$ & $63(4)$ & $-39(3)$ & $-15(3)$ & 7(3) \\
\hline C21 & $57(4)$ & $84(4)$ & $103(5)$ & $-64(4)$ & $-18(4)$ & $-1(3)$ \\
\hline $\mathrm{C} 22$ & $54(3)$ & $51(3)$ & $103(5)$ & $-36(3)$ & $-16(3)$ & $-7(2)$ \\
\hline $\mathrm{C} 23$ & $42(3)$ & $37(2)$ & $67(3)$ & $-19(2)$ & $-18(2)$ & $-2(2)$ \\
\hline C24 & $65(3)$ & $54(3)$ & $43(3)$ & $-18(2)$ & $0(3)$ & $-6(2)$ \\
\hline C25 & $69(4)$ & $78(4)$ & $84(5)$ & $-38(3)$ & $22(3)$ & $-13(3)$ \\
\hline C26 & $134(6)$ & $79(4)$ & $37(3)$ & $-13(3)$ & $-7(4)$ & $-12(4)$ \\
\hline C27 & $46(3)$ & $42(2)$ & $64(3)$ & $-7(2)$ & $-12(3)$ & $-13(2)$ \\
\hline $\mathrm{C} 28$ & $68(4)$ & $73(3)$ & $91(5)$ & $21(3)$ & $-20(4)$ & $-12(3)$ \\
\hline C29 & $52(3)$ & $53(3)$ & $96(5)$ & $-1(3)$ & $-10(3)$ & $-27(2)$ \\
\hline C30 & $35(2)$ & $45(2)$ & $38(3)$ & $-10(2)$ & $-5(2)$ & $-2(2)$ \\
\hline C31 & $52(3)$ & $47(2)$ & $33(2)$ & $-6(2)$ & $-3(2)$ & $-4(2)$ \\
\hline C32 & $31(2)$ & $47(2)$ & $51(3)$ & $-13(2)$ & $-13(2)$ & $0(2)$ \\
\hline C33 & $29(2)$ & $29(2)$ & $53(3)$ & $0(2)$ & $-2(2)$ & $-6(1)$ \\
\hline C34 & $37(2)$ & $46(2)$ & $52(3)$ & $-6(2)$ & $-3(2)$ & $-2(2)$ \\
\hline C35 & $40(3)$ & $56(3)$ & 71(4) & $-21(3)$ & $9(3)$ & $-1(2)$ \\
\hline C36 & $30(2)$ & $47(2)$ & $96(5)$ & $-5(3)$ & 7(3) & $-3(2)$ \\
\hline C37 & $39(3)$ & $52(3)$ & $81(4)$ & $6(3)$ & $-16(3)$ & $-9(2)$ \\
\hline C38 & $39(2)$ & $51(2)$ & $50(3)$ & $-1(2)$ & $-7(2)$ & $-12(2)$ \\
\hline C39 & $38(2)$ & $35(2)$ & $35(2)$ & $-3(2)$ & $-3(2)$ & $6(2)$ \\
\hline C40 & $44(3)$ & 71(3) & 41(3) & $-15(2)$ & $-6(2)$ & $2(2)$ \\
\hline C41 & $63(4)$ & $99(4)$ & $39(3)$ & $-18(3)$ & $2(3)$ & $4(3)$ \\
\hline C42 & $42(3)$ & $105(4)$ & $47(3)$ & $-16(3)$ & $6(3)$ & $-1(3)$ \\
\hline C43 & $31(2)$ & $72(3)$ & $64(4)$ & $0(3)$ & $0(2)$ & $2(2)$ \\
\hline C44 & $42(3)$ & $46(2)$ & $42(3)$ & $-6(2)$ & $-4(2)$ & $3(2)$ \\
\hline C45 & $45(3)$ & $40(2)$ & $29(2)$ & $6(2)$ & $-1(2)$ & $-3(2)$ \\
\hline
\end{tabular}




\begin{tabular}{|c|c|c|c|c|c|c|}
\hline C46 & $52(3)$ & $67(3)$ & $59(3)$ & $19(3)$ & $-19(3)$ & $-20(2)$ \\
\hline C47 & $121(6)$ & $117(5)$ & $53(4)$ & $31(4)$ & $-34(4)$ & $-82(5)$ \\
\hline C48 & $250(12)$ & 68(4) & $61(5)$ & $-6(4)$ & $-13(7)$ & $-74(7)$ \\
\hline C49 & $204(10)$ & $39(3)$ & $80(5)$ & $-2(3)$ & $38(6)$ & $0(4)$ \\
\hline C50 & $77(4)$ & $51(3)$ & $58(4)$ & $4(3)$ & $10(3)$ & $8(2)$ \\
\hline C51 & $32(2)$ & $53(2)$ & $45(3)$ & $-11(2)$ & $-10(2)$ & $-4(2)$ \\
\hline C52 & $70(4)$ & $82(4)$ & $63(4)$ & $-23(3)$ & $-22(3)$ & $17(3)$ \\
\hline C53 & $103(5)$ & $138(6)$ & $48(4)$ & $-44(4)$ & $-21(4)$ & $26(5)$ \\
\hline C54 & $93(5)$ & $139(6)$ & $44(4)$ & $2(4)$ & $-23(4)$ & $4(4)$ \\
\hline C55 & $82(4)$ & 91(4) & $63(4)$ & $2(3)$ & $-30(4)$ & $8(3)$ \\
\hline C56 & $55(3)$ & $65(3)$ & $51(3)$ & $-10(2)$ & $-19(3)$ & $3(2)$ \\
\hline $\mathrm{C} 1^{\prime}$ & $29(2)$ & $26(2)$ & $34(2)$ & $0(2)$ & $-4(2)$ & $-7(1)$ \\
\hline C2' & $33(2)$ & $30(2)$ & $29(2)$ & $-4(2)$ & $-7(2)$ & $0(1)$ \\
\hline C3' & $34(2)$ & $35(2)$ & $39(2)$ & $-6(2)$ & $-6(2)$ & $-3(2)$ \\
\hline C4' & $53(3)$ & $30(2)$ & $34(2)$ & $1(2)$ & $-9(2)$ & $-16(2)$ \\
\hline C5' & $42(2)$ & $33(2)$ & $55(3)$ & $-2(2)$ & $-10(2)$ & $2(2)$ \\
\hline C6' & $34(2)$ & $28(2)$ & $31(2)$ & $-5(2)$ & $-2(2)$ & $-8(1)$ \\
\hline C7' & $31(2)$ & $33(2)$ & $40(2)$ & $-2(2)$ & $0(2)$ & $-7(2)$ \\
\hline C8' & $30(2)$ & $56(2)$ & $53(3)$ & $-5(2)$ & $5(2)$ & $-12(2)$ \\
\hline C9' & $45(3)$ & $62(3)$ & $44(3)$ & $-3(2)$ & $16(2)$ & $-11(2)$ \\
\hline C10' & $51(3)$ & $51(2)$ & $33(2)$ & $-3(2)$ & $0(2)$ & $-13(2)$ \\
\hline C11' & $41(2)$ & $37(2)$ & $30(2)$ & $-3(2)$ & $-4(2)$ & $-7(2)$ \\
\hline C12' & $28(2)$ & $42(2)$ & $42(3)$ & $-9(2)$ & $-6(2)$ & $-4(2)$ \\
\hline C13' & $38(3)$ & $54(3)$ & $80(4)$ & $-19(3)$ & $-12(3)$ & $-11(2)$ \\
\hline C14' & $33(2)$ & $56(3)$ & $63(3)$ & $0(2)$ & $-14(2)$ & $-3(2)$ \\
\hline C15' & $40(2)$ & 41(2) & $31(2)$ & $-4(2)$ & $-6(2)$ & $-9(2)$ \\
\hline C16' & $65(3)$ & $56(3)$ & $46(3)$ & $4(2)$ & $-26(3)$ & $-10(2)$ \\
\hline C17' & $48(3)$ & $50(2)$ & $41(3)$ & $-1(2)$ & $-14(2)$ & $-16(2)$ \\
\hline C18' & $23(2)$ & $33(2)$ & $44(3)$ & $-4(2)$ & $-2(2)$ & $-1(1)$ \\
\hline C19' & $29(2)$ & $38(2)$ & $47(3)$ & $-8(2)$ & $1(2)$ & $-4(2)$ \\
\hline C20' & $37(3)$ & $53(2)$ & $56(3)$ & $-12(2)$ & $6(2)$ & $-3(2)$ \\
\hline C21' & $24(2)$ & $65(3)$ & $80(4)$ & $-15(3)$ & $3(2)$ & $-7(2)$ \\
\hline C22' & $28(2)$ & $60(3)$ & $69(4)$ & $-14(3)$ & $-11(2)$ & $-5(2)$ \\
\hline C23' & $30(2)$ & $40(2)$ & $47(3)$ & $-7(2)$ & $-9(2)$ & $0(2)$ \\
\hline C24' & $34(2)$ & $56(2)$ & $44(3)$ & $-10(2)$ & $2(2)$ & $-3(2)$ \\
\hline C25' & $53(3)$ & $73(3)$ & $66(4)$ & $-27(3)$ & $9(3)$ & $-3(2)$ \\
\hline C26' & $56(3)$ & $82(3)$ & $46(3)$ & $-2(3)$ & $-3(3)$ & $-11(3)$ \\
\hline C27' & $32(2)$ & $51(2)$ & $48(3)$ & $0(2)$ & $-15(2)$ & $-5(2)$ \\
\hline C28' & 101(5) & $59(3)$ & $68(4)$ & $11(3)$ & $-37(4)$ & $-6(3)$ \\
\hline C29' & $53(3)$ & $74(3)$ & $70(4)$ & $-19(3)$ & $-21(3)$ & $-9(2)$ \\
\hline C30' & $35(2)$ & $35(2)$ & $54(3)$ & $-6(2)$ & $-5(2)$ & $-5(2)$ \\
\hline C31' & $36(2)$ & $57(2)$ & $35(2)$ & $-3(2)$ & $-10(2)$ & $-2(2)$ \\
\hline C32' & $39(2)$ & $35(2)$ & $60(3)$ & $3(2)$ & $-11(2)$ & $-12(2)$ \\
\hline C33' & $28(2)$ & $34(2)$ & $42(3)$ & $-6(2)$ & $-9(2)$ & $-7(1)$ \\
\hline C34' & $50(3)$ & $40(2)$ & $45(3)$ & $-6(2)$ & $-7(2)$ & $-9(2)$ \\
\hline C35' & $66(3)$ & $53(3)$ & $53(3)$ & $-20(2)$ & $-1(3)$ & $-7(2)$ \\
\hline C36' & 61(3) & $39(2)$ & $75(4)$ & $-20(2)$ & $-18(3)$ & $-2(2)$ \\
\hline C37' & $66(3)$ & $32(2)$ & $68(4)$ & $-1(2)$ & $-25(3)$ & $-15(2)$ \\
\hline C38' & $42(2)$ & $44(2)$ & $45(3)$ & $0(2)$ & $-9(2)$ & $-15(2)$ \\
\hline C39' & $38(2)$ & $30(2)$ & $44(3)$ & $2(2)$ & $-8(2)$ & $1(2)$ \\
\hline C40' & $59(3)$ & $47(2)$ & $63(4)$ & $-3(2)$ & $5(3)$ & $-13(2)$ \\
\hline C41' & 75(4) & $67(3)$ & $54(4)$ & $-1(3)$ & 13(3) & $-5(3)$ \\
\hline C42' & $90(4)$ & $64(3)$ & $43(3)$ & $-15(3)$ & $-14(3)$ & $15(3)$ \\
\hline C43' & $70(4)$ & $45(2)$ & $70(4)$ & $-17(3)$ & $-27(3)$ & $-3(2)$ \\
\hline C44' & $51(3)$ & $41(2)$ & $50(3)$ & $-10(2)$ & $1(2)$ & $-4(2)$ \\
\hline C45' & $38(2)$ & $47(2)$ & $38(3)$ & $6(2)$ & $-7(2)$ & $-8(2)$ \\
\hline
\end{tabular}




\begin{tabular}{lcccccc} 
C46' & $94(5)$ & $78(4)$ & $56(4)$ & $20(3)$ & $-34(3)$ & $-30(3)$ \\
C47' & $88(5)$ & $94(4)$ & $58(4)$ & $17(3)$ & $-22(3)$ & $-39(3)$ \\
C48' & $62(4)$ & $106(5)$ & $93(5)$ & $13(4)$ & $-17(4)$ & $-26(4)$ \\
C49' & $72(5)$ & $110(5)$ & $117(7)$ & $12(5)$ & $-35(5)$ & $12(4)$ \\
C50' & $52(3)$ & $83(4)$ & $65(4)$ & $9(3)$ & $-15(3)$ & $14(3)$ \\
C51' & $42(2)$ & $36(2)$ & $53(3)$ & $-5(2)$ & $-14(2)$ & $-9(2)$ \\
C52' & $41(3)$ & $46(2)$ & $63(3)$ & $-2(2)$ & $-3(2)$ & $-9(2)$ \\
C53' & $68(4)$ & $64(3)$ & $63(4)$ & $-20(3)$ & $0(3)$ & $-14(3)$ \\
C54' & $112(5)$ & $68(3)$ & $51(4)$ & $1(3)$ & $-15(4)$ & $-6(3)$ \\
C55' & $114(5)$ & $51(3)$ & $61(4)$ & $6(3)$ & $-8(4)$ & $9(3)$ \\
C56' & $78(4)$ & $38(2)$ & $59(3)$ & $-3(2)$ & $-8(3)$ & $1(2)$ \\
\hline
\end{tabular}

Table 8. Hydrogen coordinates ( x 104) and isotropic displacement parameters $\left(\AA^{2} \times 10^{3}\right)$ for 5.

\begin{tabular}{|c|c|c|c|c|}
\hline & $\mathrm{x}$ & $\mathrm{y}$ & $\mathrm{z}$ & $\mathrm{U}(\mathrm{eq})$ \\
\hline $\mathrm{H} 3 \mathrm{~A}$ & 5850 & 4675 & 7292 & 45 \\
\hline H3B & 6075 & 4844 & 7989 & 45 \\
\hline $\mathrm{H} 4 \mathrm{~A}$ & 5037 & 3206 & 8919 & 60 \\
\hline H4B & 5544 & 3934 & 9017 & 60 \\
\hline $\mathrm{H} 4 \mathrm{C}$ & 6200 & 3282 & 8635 & 60 \\
\hline H5A & 5774 & 2359 & 7217 & 68 \\
\hline H5B & 5865 & 2364 & 7981 & 68 \\
\hline $\mathrm{H} 5 \mathrm{C}$ & 6582 & 2831 & 7430 & 68 \\
\hline H8 & 4154 & 6140 & 9619 & 57 \\
\hline H9 & 3237 & 5424 & 10461 & 64 \\
\hline H10 & 2729 & 4297 & 10253 & 57 \\
\hline H12 & 4853 & 5789 & 7923 & 46 \\
\hline H13A & 5742 & 6336 & 8924 & 77 \\
\hline H13B & 6121 & 6478 & 8149 & 77 \\
\hline H13C & 6233 & 5655 & 8513 & 77 \\
\hline H14A & 4461 & 7084 & 7920 & 77 \\
\hline H14B & 4127 & 7018 & 8703 & 77 \\
\hline $\mathrm{H} 14 \mathrm{C}$ & 3457 & 6707 & 8240 & 77 \\
\hline H15 & 3427 & 3377 & 8788 & 51 \\
\hline H16A & 2512 & 3150 & 10147 & 106 \\
\hline H16B & 3674 & 2909 & 9897 & 106 \\
\hline H16C & 2817 & 2513 & 9654 & 106 \\
\hline H17A & 1888 & 4066 & 8594 & 78 \\
\hline H17B & 1439 & 3953 & 9361 & 78 \\
\hline $\mathrm{H} 17 \mathrm{C}$ & 1649 & 3255 & 8931 & 78 \\
\hline $\mathrm{H} 20$ & 4770 & 2472 & 5281 & 78 \\
\hline $\mathrm{H} 21$ & 3583 & 1628 & 5665 & 92 \\
\hline H22 & 2847 & 1530 & 6761 & 80 \\
\hline $\mathrm{H} 24$ & 5624 & 3763 & 6243 & 65 \\
\hline H25A & 7111 & 3327 & 5541 & 117 \\
\hline H25B & 6543 & 2662 & 5366 & 117 \\
\hline
\end{tabular}




\begin{tabular}{|c|c|c|c|c|}
\hline $\mathrm{H} 25 \mathrm{C}$ & 6777 & 2680 & 6100 & 117 \\
\hline H26A & 4621 & 4207 & 5373 & 125 \\
\hline H26B & 5340 & 3664 & 4902 & 125 \\
\hline $\mathrm{H} 26 \mathrm{C}$ & 5786 & 4336 & 5163 & 125 \\
\hline H27 & 3020 & 2767 & 7972 & 60 \\
\hline $\mathrm{H} 28 \mathrm{~A}$ & 4351 & 1829 & 8153 & 117 \\
\hline H28B & 3670 & 1201 & 8039 & 117 \\
\hline $\mathrm{H} 28 \mathrm{C}$ & 3358 & 1669 & 8665 & 117 \\
\hline H29A & 1921 & 1559 & 7777 & 99 \\
\hline H29B & 1534 & 2413 & 7607 & 99 \\
\hline $\mathrm{H} 29 \mathrm{C}$ & 1625 & 2100 & 8354 & 99 \\
\hline $\mathrm{H} 30 \mathrm{~A}$ & 2767 & 5953 & 7846 & 47 \\
\hline H30B & 2071 & 5859 & 7322 & 47 \\
\hline H31A & 4822 & 4896 & 6311 & 53 \\
\hline H31B & 3791 & 5292 & 6118 & 53 \\
\hline $\mathrm{H} 32 \mathrm{~A}$ & 2181 & 3535 & 7168 & 50 \\
\hline H32B & 1421 & 4236 & 7394 & 50 \\
\hline H34 & 7167 & 4148 & 6537 & 55 \\
\hline H35 & 8883 & 3829 & 6216 & 68 \\
\hline H36 & 9963 & 3601 & 7018 & 71 \\
\hline H37 & 9312 & 3734 & 8118 & 69 \\
\hline H38 & 7592 & 4082 & 8436 & 55 \\
\hline $\mathrm{H} 40$ & 2102 & 5962 & 8982 & 62 \\
\hline H41 & 707 & 5947 & 9813 & 81 \\
\hline $\mathrm{H} 42$ & -840 & 5660 & 9607 & 79 \\
\hline $\mathrm{H} 43$ & -1001 & 5370 & 8555 & 69 \\
\hline H44 & 381 & 5364 & 7718 & 53 \\
\hline H46 & 6115 & 5645 & 6437 & 71 \\
\hline H47 & 6679 & 6829 & 6396 & 111 \\
\hline $\mathrm{H} 48$ & 5525 & 7893 & 6363 & 147 \\
\hline H49 & 3851 & 7764 & 6414 & 139 \\
\hline H50 & 3251 & 6606 & 6482 & 79 \\
\hline H52 & 2606 & 3383 & 6009 & 85 \\
\hline H53 & 2623 & 3809 & 4898 & 115 \\
\hline H54 & 1976 & 5019 & 4595 & 111 \\
\hline H55 & 1240 & 5785 & 5406 & 94 \\
\hline H56 & 1270 & 5392 & 6520 & 67 \\
\hline H3'A & 1758 & 1561 & 3012 & 43 \\
\hline H3'B & 2525 & 1960 & 2453 & 43 \\
\hline H4'A & 2072 & 2307 & 1292 & 57 \\
\hline H4'B & 1137 & 2831 & 1619 & 57 \\
\hline $\mathrm{H}^{\prime}{ }^{\prime} \mathrm{C}$ & 958 & 2216 & 1162 & 57 \\
\hline H5'A & -1248 & 2384 & 2635 & 65 \\
\hline H5'B & -558 & 2729 & 1993 & 65 \\
\hline $\mathrm{H}^{\prime} \mathrm{C}$ & -281 & 2786 & 2711 & 65 \\
\hline H8' & 4855 & 759 & 871 & 56 \\
\hline H9' & 4355 & 743 & -158 & 63 \\
\hline H10' & 2628 & 784 & -228 & 54 \\
\hline H12' & 3314 & 805 & 2447 & 44 \\
\hline H13D & 5075 & 1466 & 1757 & 84 \\
\hline H13E & 4643 & 1502 & 2524 & 84 \\
\hline $\mathrm{H} 13 \mathrm{~F}$ & 4033 & 1946 & 1976 & 84 \\
\hline H14D & 4290 & -343 & 2126 & 76 \\
\hline H14E & 4786 & 58 & 2631 & 76 \\
\hline $\mathrm{H} 14 \mathrm{~F}$ & 5232 & 128 & 1861 & 76 \\
\hline H15' & 577 & 1073 & 1065 & 44 \\
\hline
\end{tabular}




\begin{tabular}{|c|c|c|c|c|}
\hline H16D & 905 & 1834 & 40 & 81 \\
\hline H16E & -39 & 1364 & 69 & 81 \\
\hline H16F & 1025 & 1102 & -343 & 81 \\
\hline H17D & 1146 & -193 & 313 & 67 \\
\hline H17E & 25 & 31 & 665 & 67 \\
\hline $\mathrm{H} 17 \mathrm{~F}$ & 898 & -240 & 1101 & 67 \\
\hline H20' & -2871 & 990 & 4277 & 60 \\
\hline H21' & -3938 & 635 & 3615 & 68 \\
\hline H22' & -3418 & 613 & 2479 & 61 \\
\hline H24' & -306 & 1417 & 3777 & 54 \\
\hline $\mathrm{H} 25 \mathrm{D}$ & -2061 & 2088 & 4561 & 97 \\
\hline $\mathrm{H} 25 \mathrm{E}$ & -1530 & 2491 & 3884 & 97 \\
\hline $\mathrm{H} 25 \mathrm{~F}$ & -937 & 2317 & 4504 & 97 \\
\hline H26D & -1556 & 742 & 4899 & 93 \\
\hline H26E & -442 & 961 & 4903 & 93 \\
\hline $\mathrm{H} 26 \mathrm{~F}$ & -611 & 307 & 4484 & 93 \\
\hline H27' & -933 & 754 & 1620 & 51 \\
\hline H28D & -2643 & 1789 & 1397 & 112 \\
\hline $\mathrm{H} 28 \mathrm{E}$ & -1625 & 1674 & 887 & 112 \\
\hline $\mathrm{H} 28 \mathrm{~F}$ & -1613 & 2035 & 1558 & 112 \\
\hline H29D & -1997 & -190 & 1587 & 94 \\
\hline H29E & -1911 & 343 & 912 & 94 \\
\hline $\mathrm{H} 29 \mathrm{~F}$ & -2898 & 428 & 1452 & 94 \\
\hline $\mathrm{H} 30 \mathrm{C}$ & 2858 & -703 & 2194 & 50 \\
\hline H30D & 2122 & -1297 & 2532 & 50 \\
\hline $\mathrm{H} 31 \mathrm{C}$ & 944 & 443 & 3755 & 51 \\
\hline H31D & 1000 & -437 & 3817 & 51 \\
\hline $\mathrm{H} 32 \mathrm{C}$ & -823 & -368 & 2345 & 53 \\
\hline H32D & -1 & -1036 & 2120 & 53 \\
\hline H34' & 926 & 2238 & 3875 & 53 \\
\hline H35' & 563 & 3339 & 4391 & 68 \\
\hline H36' & 868 & 4480 & 3789 & 68 \\
\hline H37' & 1662 & 4515 & 2715 & 64 \\
\hline H38' & 2048 & 3418 & 2180 & 51 \\
\hline H40' & 3539 & -697 & 1058 & 69 \\
\hline H41' & 3803 & -1296 & 100 & 82 \\
\hline H42' & 2885 & -2271 & -14 & 79 \\
\hline H43' & 1647 & -2630 & 855 & 71 \\
\hline H44' & 1341 & -2045 & 1828 & 58 \\
\hline H46' & 2349 & 1020 & 4018 & 88 \\
\hline H47' & 4016 & 846 & 4365 & 94 \\
\hline H48' & 4905 & -314 & 4315 & 104 \\
\hline H49' & 4250 & -1311 & 3993 & 120 \\
\hline H50' & 2688 & -1141 & 3648 & 82 \\
\hline H52' & -1614 & -380 & 3506 & 60 \\
\hline H53' & -1934 & -964 & 4553 & 77 \\
\hline H54' & -1004 & -2072 & 4851 & 93 \\
\hline H55' & 259 & -2577 & 4073 & 94 \\
\hline H56' & 610 & -1994 & 3010 & 71 \\
\hline
\end{tabular}


Table 9. Crystal data and structure refinement for 7 .

Empirical formula

Formula weight

Temperature

Wavelength

Crystal system

Space group

Unit cell dimensions

Volume

Z

Density (calculated)

Absorption coefficient

$\mathrm{F}(000)$

Crystal size

Theta range for data collection

Index ranges

Reflections collected

Independent reflections

Completeness to theta $=27.52^{\circ}$

Absorption correction

Refinement method

Data / restraints / parameters

Goodness-of-fit on $\mathrm{F}^{2}$

Final $R$ indices [I>2sigma(I)]

$\mathrm{R}$ indices (all data)

Largest diff. peak and hole
$\mathrm{C}_{42} \mathrm{H}_{54} \mathrm{HfN}_{2}$

765.36

223(2) K

$0.71073 \AA$

Monoclinic

$\mathrm{P} 21 / \mathrm{c}$

$$
\begin{array}{ll}
\mathrm{a}=18.6846(16) \AA & \alpha=90^{\circ} \\
\mathrm{b}=10.4569(9) \AA & \beta=102.568(2)^{\circ} \\
\mathrm{c}=19.1504(17) \AA & \gamma=90^{\circ}
\end{array}
$$

3652.0(5) $\AA^{3}$

4

$1.392 \mathrm{Mg} / \mathrm{m}^{3}$

$2.887 \mathrm{~mm}^{-1}$

1568

$0.38 \times 0.28 \times 0.22 \mathrm{~mm}^{3}$

2.22 to $27.52^{\circ}$.

$-24 \leq \mathrm{h} \leq 24,-13 \leq \mathrm{k} \leq 11,-24 \leq \mathrm{l} \leq 24$

24992

$8191[\mathrm{R}(\mathrm{int})=0.0399]$

$97.3 \%$

Empirical

Full-matrix least-squares on $\mathrm{F}^{2}$

$8191 / 0 / 416$

1.034

$\mathrm{R} 1=0.0287, \mathrm{wR} 2=0.0689$ [5914]

$\mathrm{R} 1=0.0522, \mathrm{wR} 2=0.0825$

1.442 and -0.764 e. $\AA^{-3}$

$\mathrm{R} 1=\sum\left(\left\|\mathrm{F}_{\mathrm{O}}|-| \mathrm{F}_{\mathrm{C}}\right\|\right) / \sum\left|\mathrm{F}_{\mathrm{O}}\right|$

$w R 2=\left[\sum\left[w\left(\mathrm{~F}_{\mathrm{O}}{ }^{2}-\mathrm{F}_{\mathrm{c}}{ }^{2}\right)^{2}\right] / \sum\left[\mathrm{w}\left(\mathrm{F}_{\mathrm{O}}{ }^{2}\right)^{2}\right]\right]^{1 / 2}$

$\mathrm{S}=\left[\sum\left[\mathrm{w}\left(\mathrm{F}_{\mathrm{O}}^{2}-\mathrm{F}_{\mathrm{c}}{ }^{2}\right)^{2}\right] /(\mathrm{n}-\mathrm{p})\right]^{1 / 2}$

$\mathrm{w}=1 /\left[\sigma^{2}\left(\mathrm{~F}_{\mathrm{O}}{ }^{2}\right)+(\mathrm{m} * \mathrm{p})^{2}+\mathrm{n} * \mathrm{p}\right], \mathrm{p}=\left[\max \left(\mathrm{F}_{\mathrm{O}}^{2}, 0\right)+2 * \mathrm{~F}_{\mathrm{c}}{ }^{2}\right] / 3, \mathrm{~m} \& \mathrm{n}$ are constants. 
Table 10. Atomic coordinates $\left(\times 10^{4}\right)$ and equivalent isotropic displacement parameters $\left(\AA^{2} \times 10^{3}\right)$ for 7. $U(e q)$ is defined as one third of the trace of the orthogonalized $U^{i j}$ tensor.

\begin{tabular}{|c|c|c|c|c|}
\hline & $\mathrm{x}$ & $\mathrm{y}$ & $\mathrm{z}$ & $\mathrm{U}(\mathrm{eq})$ \\
\hline $\mathrm{Hf}$ & 2391(1) & $73(1)$ & $9778(1)$ & $34(1)$ \\
\hline N1 & $3265(2)$ & 619(2) & $10525(2)$ & $36(1)$ \\
\hline $\mathrm{N} 2$ & $2266(2)$ & $1937(2)$ & $9484(2)$ & $37(1)$ \\
\hline $\mathrm{C} 1$ & $2890(2)$ & 1704(3) & $10716(2)$ & $38(1)$ \\
\hline $\mathrm{C} 2$ & $2410(2)$ & 2369(3) & $10202(2)$ & $38(1)$ \\
\hline C3 & 2956(3) & 1966(4) & $11500(2)$ & $58(1)$ \\
\hline C5 & 1937(2) & $3410(3)$ & $10402(2)$ & $54(1)$ \\
\hline C6 & $3944(2)$ & 227(3) & $10970(2)$ & $38(1)$ \\
\hline C7 & $3997(2)$ & $-970(3)$ & $11319(2)$ & $43(1)$ \\
\hline $\mathrm{C} 8$ & $4661(2)$ & $-1271(4)$ & $11774(2)$ & $55(1)$ \\
\hline C9 & $5254(3)$ & $-472(5)$ & 11887(3) & $64(1)$ \\
\hline C10 & $5199(2)$ & $668(4)$ & $11539(2)$ & $55(1)$ \\
\hline C11 & $4554(2)$ & 1044(3) & 11072(2) & $45(1)$ \\
\hline C12 & $3368(2)$ & $-1887(3)$ & $11243(2)$ & $46(1)$ \\
\hline $\mathrm{C} 13$ & $3028(3)$ & $-1842(5)$ & $11888(3)$ & $80(2)$ \\
\hline C14 & $3575(3)$ & $-3250(4)$ & 11101(3) & $76(2)$ \\
\hline C15 & $4543(2)$ & 2296(4) & $10677(2)$ & $50(1)$ \\
\hline C16 & $4970(3)$ & 2153(7) & 10091(3) & $86(2)$ \\
\hline $\mathrm{C} 17$ & 4829(4) & $3408(5)$ & $11168(3)$ & $107(2)$ \\
\hline C18 & 2009(2) & 2826(3) & 8911(2) & $38(1)$ \\
\hline C19 & $1265(2)$ & 2891(3) & $8583(2)$ & $44(1)$ \\
\hline $\mathrm{C} 20$ & $1046(2)$ & $3755(3)$ & $8021(2)$ & $50(1)$ \\
\hline $\mathrm{C} 21$ & $1535(2)$ & $4556(4)$ & $7802(2)$ & $56(1)$ \\
\hline C22 & $2264(2)$ & $4477(3)$ & $8135(2)$ & $51(1)$ \\
\hline C23 & $2520(2)$ & $3616(3)$ & $8685(2)$ & $40(1)$ \\
\hline $\mathrm{C} 24$ & $680(2)$ & $2095(4)$ & 8798(3) & $62(1)$ \\
\hline $\mathrm{C} 25$ & $140(3)$ & 2911(5) & $9095(3)$ & $78(2)$ \\
\hline C26 & $262(3)$ & $1285(4)$ & $8171(3)$ & $77(2)$ \\
\hline C27 & $3330(2)$ & 3592(3) & 9019(2) & $42(1)$ \\
\hline C28 & $3531(3)$ & 4721(4) & $9520(3)$ & $63(1)$ \\
\hline C29 & $3798(2)$ & $3568(4)$ & $8462(2)$ & $58(1)$ \\
\hline C30 & $1512(2)$ & $-439(4)$ & $10358(2)$ & $52(1)$ \\
\hline C31 & 1102(2) & $-1424(3)$ & 9888(2) & $50(1)$ \\
\hline C32 & $1372(3)$ & $-2657(4)$ & 9864(3) & $68(1)$ \\
\hline C33 & $1008(4)$ & $-3560(4)$ & 9395(3) & $89(2)$ \\
\hline C34 & $359(4)$ & $-3267(5)$ & 8936(3) & $87(2)$ \\
\hline C35 & 71(3) & $-2062(4)$ & 8951(3) & $70(1)$ \\
\hline $\mathrm{C} 36$ & $441(2)$ & $-1154(4)$ & $9415(2)$ & $55(1)$ \\
\hline C37 & 2887(3) & $-1503(4)$ & $9246(2)$ & $61(1)$ \\
\hline $\mathrm{C} 38$ & $2483(2)$ & $-1076(3)$ & $8546(2)$ & $49(1)$ \\
\hline C39 & 1884(3) & $-1729(4)$ & $8154(3)$ & $62(1)$ \\
\hline $\mathrm{C} 40$ & 1499(3) & $-1283(6)$ & $7518(3)$ & $89(2)$ \\
\hline C41 & 1672(4) & $-125(6)$ & $7265(4)$ & $100(2)$ \\
\hline C42 & $2229(5)$ & $558(5)$ & 7650(4) & $97(2)$ \\
\hline C43 & $2638(3)$ & 101(4) & $8284(3)$ & $73(2)$ \\
\hline
\end{tabular}


Table 11. Bond lengths $[\AA]$ and angles $\left[{ }^{\circ}\right]$ for 7.

\begin{tabular}{|c|c|c|c|}
\hline Hf-N1 & $2.005(3)$ & N1-Hf-C30 & $106.60(14)$ \\
\hline Hf-N2 & $2.028(3)$ & N2-Hf-C30 & $108.31(13)$ \\
\hline Hf-C30 & $2.239(4)$ & N1-Hf-C37 & $100.41(14)$ \\
\hline Hf-C37 & $2.242(4)$ & N2-Hf-C37 & $127.96(15)$ \\
\hline $\mathrm{Hf}-\mathrm{C} 1$ & $2.505(3)$ & C30-Hf-C37 & $118.04(16)$ \\
\hline $\mathrm{Hf}-\mathrm{C} 2$ & $2.533(3)$ & N1-Hf-C1 & $34.55(11)$ \\
\hline Hf-C38 & $2.687(4)$ & N2-Hf-C1 & $63.07(11)$ \\
\hline N1-C1 & $1.422(4)$ & C30-Hf-C1 & $90.35(14)$ \\
\hline N1-C6 & $1.427(4)$ & C37-Hf-C1 & $134.44(14)$ \\
\hline $\mathrm{N} 2-\mathrm{C} 2$ & $1.417(4)$ & N1-Hf-C2 & $63.17(11)$ \\
\hline N2-C18 & $1.439(4)$ & N2-Hf-C2 & $33.96(11)$ \\
\hline $\mathrm{C} 1-\mathrm{C} 2$ & $1.368(5)$ & C30-Hf-C2 & $91.60(13)$ \\
\hline C1-C3 & $1.506(5)$ & C37-Hf-C2 & $149.86(16)$ \\
\hline C2-C5 & $1.503(5)$ & C1-Hf-C2 & $31.51(11)$ \\
\hline C6-C11 & $1.404(5)$ & N1-Hf-C38 & $123.78(12)$ \\
\hline C6-C7 & $1.411(5)$ & N2-Hf-C38 & $102.24(12)$ \\
\hline C7-C8 & $1.389(5)$ & C30-Hf-C38 & $121.52(14)$ \\
\hline C7-C12 & $1.499(5)$ & C37-Hf-C38 & $32.88(14)$ \\
\hline C8-C9 & $1.367(6)$ & C1-Hf-C38 & $148.12(12)$ \\
\hline C9-C10 & $1.359(6)$ & C2-Hf-C38 & $134.98(12)$ \\
\hline C10-C11 & $1.391(5)$ & C1-N1-C6 & $119.9(3)$ \\
\hline C11-C15 & $1.509(5)$ & C1-N1-Hf & $92.4(2)$ \\
\hline C12-C13 & $1.508(6)$ & C6-N1-Hf & $145.6(2)$ \\
\hline C12-C14 & $1.517(5)$ & C2-N2-C18 & 119.7(3) \\
\hline C15-C17 & $1.517(6)$ & C2-N2-Hf & $92.97(19)$ \\
\hline C15-C16 & $1.518(6)$ & C18-N2-Hf & $146.3(2)$ \\
\hline C18-C19 & $1.398(5)$ & $\mathrm{C} 2-\mathrm{C} 1-\mathrm{N} 1$ & $120.2(3)$ \\
\hline C18-C23 & $1.400(5)$ & $\mathrm{C} 2-\mathrm{C} 1-\mathrm{C} 3$ & $121.6(3)$ \\
\hline C19-C20 & $1.396(5)$ & $\mathrm{N} 1-\mathrm{C} 1-\mathrm{C} 3$ & $117.6(3)$ \\
\hline C19-C24 & $1.501(5)$ & C2-C1-Hf & $75.3(2)$ \\
\hline C20-C21 & $1.371(6)$ & N1-C1-Hf & $53.09(16)$ \\
\hline $\mathrm{C} 21-\mathrm{C} 22$ & $1.375(6)$ & C3-C1-Hf & $140.9(3)$ \\
\hline $\mathrm{C} 22-\mathrm{C} 23$ & $1.390(5)$ & $\mathrm{C} 1-\mathrm{C} 2-\mathrm{N} 2$ & $119.5(3)$ \\
\hline $\mathrm{C} 23-\mathrm{C} 27$ & $1.509(5)$ & $\mathrm{C} 1-\mathrm{C} 2-\mathrm{C} 5$ & $121.0(3)$ \\
\hline $\mathrm{C} 24-\mathrm{C} 25$ & $1.522(7)$ & $\mathrm{N} 2-\mathrm{C} 2-\mathrm{C} 5$ & $118.7(3)$ \\
\hline C24-C26 & $1.537(6)$ & $\mathrm{C} 1-\mathrm{C} 2-\mathrm{Hf}$ & 73.14(19) \\
\hline $\mathrm{C} 27-\mathrm{C} 28$ & $1.517(5)$ & N2-C2-Hf & $53.08(14)$ \\
\hline C27-C29 & $1.518(5)$ & C5-C2-Hf & $143.2(3)$ \\
\hline C30-C31 & $1.468(6)$ & C11-C6-C7 & $120.2(3)$ \\
\hline C31-C32 & $1.389(5)$ & C11-C6-N1 & $119.9(3)$ \\
\hline C31-C36 & $1.392(6)$ & C7-C6-N1 & $120.0(3)$ \\
\hline C32-C33 & $1.377(7)$ & C8-C7-C6 & $117.4(4)$ \\
\hline C33-C34 & $1.368(7)$ & C8-C7-C12 & $119.3(3)$ \\
\hline C34-C35 & $1.374(7)$ & C6-C7-C12 & $123.3(3)$ \\
\hline C35-C36 & $1.379(6)$ & C9-C8-C7 & $122.9(4)$ \\
\hline C37-C38 & $1.458(6)$ & C10-C9-C8 & $119.1(4)$ \\
\hline C38-C43 & $1.382(6)$ & C9-C10-C11 & $121.7(4)$ \\
\hline C38-C39 & $1.385(6)$ & C10-C11-C6 & $118.7(4)$ \\
\hline C39-C40 & $1.356(7)$ & C10-C11-C15 & $118.8(4)$ \\
\hline C40-C41 & $1.369(8)$ & C6-C11-C15 & $122.4(3)$ \\
\hline $\mathrm{C} 41-\mathrm{C} 42$ & $1.342(9)$ & C7-C12-C13 & $111.2(3)$ \\
\hline \multirow[t]{2}{*}{$\mathrm{C} 42-\mathrm{C} 43$} & $1.373(9)$ & C7-C12-C14 & $113.2(4)$ \\
\hline & & C13-C12-C14 & $110.2(4)$ \\
\hline N1-Hf-N2 & $87.19(11)$ & C11-C15-C17 & $113.0(4)$ \\
\hline
\end{tabular}




$\begin{array}{lr}\text { C11-C15-C16 } & 109.4(4) \\ \text { C17-C15-C16 } & 111.2(4) \\ \text { C19-C18-C23 } & 120.7(3) \\ \text { C19-C18-N2 } & 120.5(3) \\ \text { C23-C18-N2 } & 118.7(3) \\ \text { C20-C19-C18 } & 118.3(3) \\ \text { C20-C19-C24 } & 117.5(4) \\ \text { C18-C19-C24 } & 124.2(3) \\ \text { C21-C20-C19 } & 121.8(4) \\ \text { C20-C21-C22 } & 118.8(4) \\ \text { C21-C22-C23 } & 122.2(4) \\ \text { C22-C23-C18 } & 118.1(3) \\ \text { C22-C23-C27 } & 118.7(3) \\ \text { C18-C23-C27 } & 123.2(3) \\ \text { C19-C24-C25 } & 111.9(4) \\ \text { C19-C24-C26 } & 111.6(4) \\ \text { C25-C24-C26 } & 109.6(4) \\ \text { C23-C27-C28 } & 110.0(3) \\ \text { C23-C27-C29 } & 112.4(3) \\ \text { C28-C27-C29 } & 110.9(3) \\ \text { C31-C30-Hf } & 101.8(3) \\ \text { C32-C31-C36 } & 116.3(4) \\ \text { C32-C31-C30 } & 121.8(4) \\ \text { C36-C31-C30 } & 121.8(4) \\ \text { C33-C32-C31 } & 121.8(5) \\ \text { C34-C33-C32 } & 120.6(5) \\ \text { C33-C34-C35 } & 119.3(5) \\ \text { C34-C35-C36 } & 120.0(5) \\ \text { C35-C36-C31 } & 122.0(4) \\ \text { C38-C37-Hf } & 90.6(2) \\ \text { C43-C38-C39 } & 116.8(5) \\ \text { C43-C38-C37 } & 119.9(4) \\ \text { C39-C38-C37 } & 122.9(4) \\ \text { C43-C38-Hf } & 121.7(3) \\ \text { C39-C38-Hf } & 120.1(6) \\ \text { C37-C38-Hf } & 119.4(6) \\ \text { C40-C39-C38 } & 121.0(5) \\ \text { C39-C40-C41 } & 120.7(5) \\ \text { C42-C41-C40 } & \\ \text { C41-C42-C43 } & \\ \text { C42-C43-C38 } & \\ & \end{array}$

DOW RESTRICTED - For internal use only 
Table 12. Anisotropic displacement parameters $\left(\AA^{2} \times 10^{3}\right)$ for 7. The anisotropic displacement factor exponent takes the form: $-2 \pi^{2}\left[h^{2} a^{* 2} U^{11}+\ldots+2 h k a^{*} b^{*} U^{12}\right]$

\begin{tabular}{|c|c|c|c|c|c|c|}
\hline & $\mathrm{U}^{11}$ & $\mathrm{U}^{22}$ & $\mathrm{U}^{33}$ & $\mathrm{U}^{23}$ & $\mathrm{U}^{13}$ & $\mathrm{U}^{12}$ \\
\hline $\mathrm{Hf}$ & $33(1)$ & $32(1)$ & $35(1)$ & 1(1) & $6(1)$ & $0(1)$ \\
\hline N1 & $38(2)$ & $40(1)$ & $30(2)$ & $2(1)$ & $6(1)$ & $3(1)$ \\
\hline N2 & $39(2)$ & $35(1)$ & $33(2)$ & $3(1)$ & $3(1)$ & 1(1) \\
\hline $\mathrm{C} 1$ & $44(2)$ & $39(2)$ & $33(2)$ & 2(2) & $10(2)$ & $1(2)$ \\
\hline $\mathrm{C} 2$ & $44(2)$ & $37(2)$ & $35(2)$ & $-1(1)$ & $10(2)$ & $-1(1)$ \\
\hline C3 & $78(3)$ & $62(2)$ & $34(2)$ & $-1(2)$ & $13(2)$ & $20(2)$ \\
\hline C5 & $66(3)$ & $49(2)$ & $45(2)$ & $-3(2)$ & $6(2)$ & $15(2)$ \\
\hline C6 & $40(2)$ & $46(2)$ & $26(2)$ & $-1(1)$ & $4(2)$ & $5(2)$ \\
\hline C7 & $50(2)$ & $47(2)$ & $31(2)$ & $-3(2)$ & $5(2)$ & $9(2)$ \\
\hline C8 & $62(3)$ & $56(2)$ & $43(2)$ & $6(2)$ & 1(2) & $15(2)$ \\
\hline C9 & $49(3)$ & $77(3)$ & $56(3)$ & $0(2)$ & $-9(2)$ & $12(2)$ \\
\hline C10 & $44(2)$ & $67(2)$ & $50(3)$ & $0(2)$ & $-2(2)$ & $0(2)$ \\
\hline C11 & $43(2)$ & $56(2)$ & $32(2)$ & $-4(2)$ & $2(2)$ & 1(2) \\
\hline C12 & $57(3)$ & $41(2)$ & $38(2)$ & $7(2)$ & $9(2)$ & $7(2)$ \\
\hline C13 & $96(4)$ & $86(3)$ & $66(3)$ & $-5(3)$ & $36(3)$ & $-12(3)$ \\
\hline C14 & $96(4)$ & $47(2)$ & $86(4)$ & $-8(2)$ & 21(3) & $5(2)$ \\
\hline C15 & $45(2)$ & $57(2)$ & $44(2)$ & $2(2)$ & $2(2)$ & $-9(2)$ \\
\hline C16 & $66(4)$ & $123(5)$ & $75(4)$ & $38(3)$ & $29(3)$ & $25(3)$ \\
\hline C17 & $153(6)$ & $70(3)$ & $75(4)$ & $5(3)$ & $-27(4)$ & $-43(3)$ \\
\hline C18 & $44(2)$ & $33(1)$ & $38(2)$ & $6(1)$ & $8(2)$ & $3(1)$ \\
\hline C19 & $43(2)$ & $44(2)$ & $44(2)$ & $8(2)$ & $5(2)$ & $4(2)$ \\
\hline C20 & $44(2)$ & $56(2)$ & $48(2)$ & $14(2)$ & 2(2) & $8(2)$ \\
\hline C21 & $55(3)$ & $55(2)$ & $56(3)$ & $22(2)$ & $9(2)$ & $9(2)$ \\
\hline C22 & $54(3)$ & $46(2)$ & $55(3)$ & $16(2)$ & $14(2)$ & $2(2)$ \\
\hline $\mathrm{C} 23$ & $45(2)$ & $37(2)$ & $36(2)$ & $1(1)$ & $8(2)$ & 1(2) \\
\hline C24 & $46(3)$ & $63(2)$ & $70(3)$ & $28(2)$ & $0(2)$ & $-7(2)$ \\
\hline $\mathrm{C} 25$ & $53(3)$ & $116(4)$ & $67(3)$ & 11(3) & $18(3)$ & $-12(3)$ \\
\hline C26 & $58(3)$ & $66(3)$ & $99(4)$ & $10(3)$ & $-5(3)$ & $-10(2)$ \\
\hline $\mathrm{C} 27$ & $46(2)$ & $37(2)$ & $40(2)$ & $3(2)$ & $6(2)$ & $-4(2)$ \\
\hline C28 & $62(3)$ & $57(2)$ & $67(3)$ & $-12(2)$ & $7(2)$ & $-6(2)$ \\
\hline C29 & $53(3)$ & $67(2)$ & $52(3)$ & $6(2)$ & $10(2)$ & $-3(2)$ \\
\hline C30 & $46(2)$ & $51(2)$ & $63(3)$ & $8(2)$ & $19(2)$ & $0(2)$ \\
\hline C31 & $46(2)$ & $47(2)$ & 61(3) & $13(2)$ & $21(2)$ & $-2(2)$ \\
\hline C32 & $62(3)$ & $58(2)$ & 79(4) & $14(2)$ & 4(3) & $7(2)$ \\
\hline C33 & $114(5)$ & $48(2)$ & $96(4)$ & $3(3)$ & 6(4) & $9(3)$ \\
\hline C34 & $113(5)$ & $58(3)$ & $82(4)$ & $-2(3)$ & $7(4)$ & $-13(3)$ \\
\hline C35 & $68(3)$ & $69(3)$ & $70(3)$ & 13(3) & 7(3) & $-4(2)$ \\
\hline C36 & $54(3)$ & $49(2)$ & $65(3)$ & $12(2)$ & 19(2) & $-2(2)$ \\
\hline C37 & $52(3)$ & $73(3)$ & $57(3)$ & $-14(2)$ & $10(2)$ & $13(2)$ \\
\hline C38 & $49(2)$ & $48(2)$ & $54(3)$ & $-15(2)$ & $20(2)$ & $-1(2)$ \\
\hline C39 & $62(3)$ & $67(2)$ & $56(3)$ & $-1(2)$ & $11(2)$ & $-17(2)$ \\
\hline C40 & $67(4)$ & $127(5)$ & $67(4)$ & 3(4) & $5(3)$ & $-11(3)$ \\
\hline C41 & $109(6)$ & $123(5)$ & $69(4)$ & $26(4)$ & $24(4)$ & $36(4)$ \\
\hline C42 & $149(7)$ & $70(3)$ & $85(5)$ & $9(3)$ & $56(5)$ & $-10(4)$ \\
\hline C43 & $87(4)$ & $69(3)$ & $71(4)$ & $-18(3)$ & $35(3)$ & $-32(3)$ \\
\hline
\end{tabular}


Table 13. Hydrogen coordinates ( x 104) and isotropic displacement parameters $\left(\AA^{2} \times 10^{3}\right)$ for 7 .

\begin{tabular}{|c|c|c|c|c|}
\hline & $\mathrm{x}$ & $\mathrm{y}$ & $\mathrm{Z}$ & $\mathrm{U}(\mathrm{eq})$ \\
\hline H3A & 3012 & 2878 & 11588 & 87 \\
\hline H3B & 3381 & 1522 & 11775 & 87 \\
\hline $\mathrm{H} 3 \mathrm{C}$ & 2518 & 1667 & 11644 & 87 \\
\hline H5A & 1562 & 3033 & 10617 & 81 \\
\hline H5B & 1707 & 3883 & 9977 & 81 \\
\hline H5C & 2238 & 3985 & 10742 & 81 \\
\hline H8 & 4704 & -2059 & 12017 & 66 \\
\hline H9 & 5694 & -709 & 12200 & 76 \\
\hline H10 & 5606 & 1218 & 11616 & 66 \\
\hline H12 & 2989 & -1608 & 10825 & 55 \\
\hline H13A & 3386 & -2108 & 12309 & 119 \\
\hline H13B & 2609 & -2413 & 11815 & 119 \\
\hline H13C & 2869 & -976 & 11955 & 119 \\
\hline H14A & 3787 & -3269 & 10682 & 114 \\
\hline H14B & 3141 & -3785 & 11020 & 114 \\
\hline $\mathrm{H} 14 \mathrm{C}$ & 3930 & -3568 & 11511 & 114 \\
\hline H15 & 4027 & 2484 & 10445 & 60 \\
\hline H16A & 5473 & 1919 & 10303 & 129 \\
\hline H16B & 4963 & 2957 & 9838 & 129 \\
\hline H16C & 4746 & 1492 & 9760 & 129 \\
\hline H17A & 4564 & 3451 & 11550 & 161 \\
\hline H17B & 4760 & 4198 & 10896 & 161 \\
\hline $\mathrm{H} 17 \mathrm{C}$ & 5347 & 3285 & 11371 & 161 \\
\hline $\mathrm{H} 220$ & 549 & 3788 & 7786 & 61 \\
\hline $\mathrm{H} 21$ & 1375 & 5148 & 7432 & 67 \\
\hline $\mathrm{H} 22$ & 2601 & 5024 & 7984 & 62 \\
\hline $\mathrm{H} 24$ & 922 & 1504 & 9181 & 74 \\
\hline $\mathrm{H} 25 \mathrm{~A}$ & 389 & 3294 & 9543 & 117 \\
\hline $\mathrm{H} 25 \mathrm{~B}$ & -259 & 2378 & 9175 & 117 \\
\hline $\mathrm{H} 25 \mathrm{C}$ & -53 & 3579 & 8754 & 117 \\
\hline $\mathrm{H} 26 \mathrm{~A}$ & 66 & 1838 & 7768 & 116 \\
\hline H26B & -138 & 840 & 8316 & 116 \\
\hline $\mathrm{H} 26 \mathrm{C}$ & 593 & 667 & 8034 & 116 \\
\hline $\mathrm{H} 27$ & 3433 & 2801 & 9307 & 50 \\
\hline $\mathrm{H} 28 \mathrm{~A}$ & 3418 & 5511 & 9253 & 95 \\
\hline $\mathrm{H} 28 \mathrm{~B}$ & 4051 & 4693 & 9736 & 95 \\
\hline $\mathrm{H} 28 \mathrm{C}$ & 3253 & 4682 & 9892 & 95 \\
\hline H29A & 3654 & 2849 & 8143 & 87 \\
\hline H29B & 4310 & 3483 & 8699 & 87 \\
\hline $\mathrm{H} 29 \mathrm{C}$ & 3728 & 4357 & 8190 & 87 \\
\hline H30A & 1720 & -779 & 10835 & 63 \\
\hline H30B & 1201 & 300 & 10401 & 63 \\
\hline H32 & 1816 & -2880 & 10176 & 82 \\
\hline H33 & 1206 & -4385 & 9391 & 106 \\
\hline H34 & 114 & -3884 & 8614 & 104 \\
\hline H35 & -380 & -1856 & 8644 & 84 \\
\hline H36 & 242 & -329 & 9412 & 66 \\
\hline H37A & 3420 & -1434 & 9309 & 73 \\
\hline H37B & 2748 & -2361 & 9375 & 73 \\
\hline H39 & 1741 & -2502 & 8334 & 74 \\
\hline $\mathrm{H} 40$ & 1112 & -1771 & 7250 & 106 \\
\hline
\end{tabular}


H41

$\mathrm{H} 42$

H43
1402

2341

3027
190

1362

593
6827

7482

8544
116

88

DOW RESTRICTED - For internal use only 
Table 14. Crystal data and structure refinement for $\mathbf{8}$.

Empirical formula

Formula weight

Temperature

Wavelength

Crystal system

Space group

Unit cell dimensions

Volume

Z

Density (calculated)

Absorption coefficient

$\mathrm{F}(000)$

Crystal size

Theta range for data collection

Index ranges

Reflections collected

Independent reflections

Completeness to theta $=27.59^{\circ}$

Absorption correction

Refinement method

Data / restraints / parameters

Goodness-of-fit on $\mathrm{F}^{2}$

Final $R$ indices [I>2sigma(I)]

$\mathrm{R}$ indices (all data)

Largest diff. peak and hole
$\mathrm{C}_{42} \mathrm{H}_{54} \mathrm{~N}_{2} \mathrm{Zr}$

678.09

223(2) K

$0.71073 \AA$

Monoclinic

$\mathrm{P} 21 / \mathrm{c}$

$$
\begin{array}{ll}
\mathrm{a}=18.6901(9) \AA & \alpha=90^{\circ} . \\
\mathrm{b}=10.5637(5) \AA & \beta=102.335(1)^{\circ} . \\
\mathrm{c}=19.1698(9) \AA & \gamma=90^{\circ} .
\end{array}
$$

3697.4(3) $\AA^{3}$

4

$1.218 \mathrm{Mg} / \mathrm{m}^{3}$

$0.327 \mathrm{~mm}^{-1}$

1440

$0.44 \times 0.42 \times 0.20 \mathrm{~mm}^{3}$

2.17 to $27.59^{\circ}$.

$-24<=\mathrm{h}<=24,-12<=\mathrm{k}<=13,-24<=\mathrm{l}<=24$

24113

$8326[\mathrm{R}(\mathrm{int})=0.0340]$

$97.2 \%$

Semi-empirical

Full-matrix least-squares on $\mathrm{F}^{2}$

$8326 / 0 / 416$

1.051

$\mathrm{R} 1=0.0372, \mathrm{wR} 2=0.1004$ [7299]

$\mathrm{R} 1=0.0433, \mathrm{wR} 2=0.1072$

0.595 and -0.391 e. $\AA^{-3}$

$$
\begin{aligned}
& \mathrm{R} 1=\sum\left(\left\|\mathrm{F}_{\mathrm{O}}|-| \mathrm{F}_{\mathrm{c}}\right\|\right) / \sum\left|\mathrm{F}_{\mathrm{O}}\right| \\
& \left.\mathrm{wR} 2=\left[\sum\left[\mathrm{w}\left(\mathrm{F}_{\mathrm{O}}{ }^{2}-\mathrm{F}_{\mathrm{c}}^{2}\right)^{2}\right] / \sum\left[\mathrm{w}\left(\mathrm{F}_{\mathrm{O}}^{2}\right)^{2}\right]\right]\right]^{1 / 2} \\
& \mathrm{~S}=\left[\sum\left[\mathrm{w}\left(\mathrm{F}_{\mathrm{O}}^{2}-\mathrm{F}_{\mathrm{c}}{ }^{2}\right)^{2}\right] /(\mathrm{n}-\mathrm{p})\right]^{1 / 2} \\
& \mathrm{w}=1 /\left[\sigma^{2}\left(\mathrm{~F}_{\mathrm{O}}^{2}\right)+(\mathrm{m} * \mathrm{p})^{2}+\mathrm{n} * \mathrm{p}\right], \mathrm{p}=\left[\max \left(\mathrm{F}_{\mathrm{O}}^{2}, 0\right)+2 * \mathrm{~F}_{\mathrm{c}}^{2}\right] / 3, \mathrm{~m} \& \mathrm{n} \text { are constants. }
\end{aligned}
$$


Table 15. Atomic coordinates ( $\times 10^{4}$ ) and equivalent isotropic displacement parameters $\left(\AA^{2} \times 10^{3}\right)$ for 8. $U(e q)$ is defined as one third of the trace of the orthogonalized $U^{i j}$ tensor.

\begin{tabular}{|c|c|c|c|c|}
\hline & $\mathrm{x}$ & $\mathrm{y}$ & $\mathrm{z}$ & $\mathrm{U}(\mathrm{eq})$ \\
\hline $\mathrm{Zr} 1$ & $7647(1)$ & $5143(1)$ & $5225(1)$ & $30(1)$ \\
\hline N1 & 6751(1) & $5681(1)$ & $4479(1)$ & $32(1)$ \\
\hline $\mathrm{N} 2$ & $7775(1)$ & $7029(1)$ & $5493(1)$ & $32(1)$ \\
\hline $\mathrm{C} 1$ & 7137(1) & 6732(2) & $4269(1)$ & $34(1)$ \\
\hline $\mathrm{C} 2$ & $7628(1)$ & $7412(2)$ & $4771(1)$ & $34(1)$ \\
\hline C3 & $7080(1)$ & $6943(2)$ & $3478(1)$ & $51(1)$ \\
\hline C5 & $8109(1)$ & $8414(2)$ & 4543(1) & $49(1)$ \\
\hline C6 & $6066(1)$ & $5304(2)$ & $4036(1)$ & $36(1)$ \\
\hline C7 & $5996(1)$ & $4102(2)$ & $3698(1)$ & $40(1)$ \\
\hline $\mathrm{C} 8$ & $5322(1)$ & $3788(2)$ & $3254(1)$ & $53(1)$ \\
\hline C9 & 4733(1) & 4603(3) & $3145(1)$ & $61(1)$ \\
\hline $\mathrm{C} 10$ & $4802(1)$ & $5758(2)$ & $3485(1)$ & $54(1)$ \\
\hline C11 & $5461(1)$ & $6130(2)$ & $3936(1)$ & $41(1)$ \\
\hline $\mathrm{C} 12$ & $6626(1)$ & $3171(2)$ & $3769(1)$ & $43(1)$ \\
\hline C13 & 6963(2) & $3205(3)$ & $3117(2)$ & $72(1)$ \\
\hline C14 & $6406(2)$ & 1821(2) & $3917(2)$ & $65(1)$ \\
\hline C15 & $5487(1)$ & $7395(2)$ & $4318(1)$ & $45(1)$ \\
\hline C16 & $5023(1)$ & $7345(3)$ & $4883(2)$ & $75(1)$ \\
\hline C17 & $5246(2)$ & 8494(3) & 3801(2) & $89(1)$ \\
\hline C18 & $8028(1)$ & $7920(2)$ & $6058(1)$ & $33(1)$ \\
\hline C19 & $8778(1)$ & $8010(2)$ & 6383(1) & $39(1)$ \\
\hline C20 & 8996(1) & $8846(2)$ & $6955(1)$ & $46(1)$ \\
\hline C21 & 8498(1) & 9591(2) & $7200(1)$ & $49(1)$ \\
\hline C22 & $7765(1)$ & $9511(2)$ & $6876(1)$ & $45(1)$ \\
\hline C23 & $7515(1)$ & $8678(2)$ & $6310(1)$ & $35(1)$ \\
\hline C24 & 9374(1) & 7261(2) & 6135(1) & $50(1)$ \\
\hline C25 & 9910(1) & $8140(3)$ & $5867(2)$ & $66(1)$ \\
\hline $\mathrm{C} 26$ & $9783(1)$ & $6408(2)$ & $6733(2)$ & $68(1)$ \\
\hline C27 & 6703(1) & $8640(2)$ & $5979(1)$ & $37(1)$ \\
\hline C28 & 6493(2) & $9778(2)$ & $5484(2)$ & $57(1)$ \\
\hline C29 & $6229(1)$ & $8583(2)$ & $6537(1)$ & $51(1)$ \\
\hline C30 & $8506(1)$ & $4633(2)$ & 4582(1) & $48(1)$ \\
\hline C31 & $8870(1)$ & $3661(2)$ & $5086(1)$ & $45(1)$ \\
\hline C32 & $8546(1)$ & $2460(2)$ & $5130(1)$ & $56(1)$ \\
\hline C33 & $8870(2)$ & 1571(2) & $5626(2)$ & $67(1)$ \\
\hline C34 & $9519(2)$ & $1828(2)$ & 6093(2) & $68(1)$ \\
\hline $\mathrm{C} 35$ & $9846(2)$ & $3005(2)$ & $6072(2)$ & $63(1)$ \\
\hline C36 & 9523(1) & 3897(2) & 5583(1) & $51(1)$ \\
\hline C37 & 7019(1) & $3643(2)$ & $5729(1)$ & $48(1)$ \\
\hline C38 & $7466(1)$ & $4022(2)$ & $6417(1)$ & $41(1)$ \\
\hline C39 & $8028(1)$ & $3263(2)$ & 6812(1) & $55(1)$ \\
\hline C40 & $8471(2)$ & $3679(3)$ & 7433(1) & $69(1)$ \\
\hline C41 & $8398(2)$ & $4890(3)$ & $7686(2)$ & $72(1)$ \\
\hline C42 & 7877(2) & $5672(3)$ & 7306(1) & $71(1)$ \\
\hline C43 & $7413(2)$ & $5251(2)$ & $6680(1)$ & $54(1)$ \\
\hline
\end{tabular}


Table 16. Bond lengths $[\AA]$ and angles $\left[{ }^{\circ}\right]$ for 8 .

\begin{tabular}{|c|c|c|c|}
\hline $\mathrm{Zr1-N1}$ & $2.037(1)$ & $\mathrm{N} 1-\mathrm{Zr} 1-\mathrm{N} 2$ & $86.51(6)$ \\
\hline $\mathrm{Zr} 1-\mathrm{N} 2$ & $2.060(1)$ & $\mathrm{N} 1-\mathrm{Zr} 1-\mathrm{C} 30$ & $104.69(7)$ \\
\hline Zr1-C30 & $2.287(2)$ & N2-Zr1-C30 & $107.74(7)$ \\
\hline Zr1-C37 & $2.303(2)$ & N1-Zr1-C37 & $94.06(7)$ \\
\hline Zr1-C1 & $2.518(2)$ & N2-Zr1-C37 & $127.11(7)$ \\
\hline $\mathrm{Zr} 1-\mathrm{C} 2$ & $2.548(2)$ & C30-Zr1-C37 & $122.92(8)$ \\
\hline Zr1-C38 & $2.659(2)$ & N1-Zr1-C1 & $34.53(5)$ \\
\hline Zr1-C31 & $2.830(2)$ & $\mathrm{N} 2-\mathrm{Zr} 1-\mathrm{C} 1$ & $62.75(6)$ \\
\hline $\mathrm{N} 1-\mathrm{C} 1$ & $1.427(2)$ & C30-Zr1-C1 & $87.99(7)$ \\
\hline N1-C6 & $1.434(2)$ & $\mathrm{C} 37-\mathrm{Zr} 1-\mathrm{C} 1$ & $128.06(7)$ \\
\hline $\mathrm{N} 2-\mathrm{C} 2$ & $1.412(2)$ & N1-Zr1-C2 & $63.12(6)$ \\
\hline N2-C18 & $1.436(2)$ & $\mathrm{N} 2-\mathrm{Zr} 1-\mathrm{C} 2$ & $33.63(5)$ \\
\hline $\mathrm{C} 1-\mathrm{C} 2$ & $1.380(2)$ & $\mathrm{C} 30-\mathrm{Zr} 1-\mathrm{C} 2$ & $89.84(7)$ \\
\hline C1-C3 & $1.513(2)$ & $\mathrm{C} 37-\mathrm{Zr} 1-\mathrm{C} 2$ & $145.02(7)$ \\
\hline $\mathrm{C} 2-\mathrm{C} 5$ & $1.513(2)$ & $\mathrm{C} 1-\mathrm{Zr} 1-\mathrm{C} 2$ & $31.61(5)$ \\
\hline C6-C11 & $1.410(3)$ & $\mathrm{N} 1-\mathrm{Zr} 1-\mathrm{C} 38$ & $119.46(6)$ \\
\hline C6-C7 & $1.418(3)$ & N2-Zr1-C38 & $104.22(6)$ \\
\hline C7-C8 & $1.401(3)$ & C30-Zr1-C38 & $126.23(7)$ \\
\hline C7-C12 & $1.518(3)$ & C37-Zr1-C38 & $33.22(7)$ \\
\hline C8-C9 & $1.378(4)$ & C1-Zr1-C38 & $145.57(6)$ \\
\hline C9-C10 & $1.376(3)$ & C2-Zr1-C38 & $135.87(6)$ \\
\hline C10-C11 & $1.401(3)$ & N1-Zr1-C31 & $130.38(6)$ \\
\hline C11-C15 & $1.520(3)$ & N2-Zr1-C31 & $120.37(6)$ \\
\hline C12-C13 & $1.516(3)$ & C30-Zr1-C31 & $31.24(7)$ \\
\hline C12-C14 & $1.526(3)$ & C37-Zr1-C31 & $98.82(7)$ \\
\hline C15-C16 & $1.525(3)$ & C1-Zr1-C31 & $119.22(6)$ \\
\hline C15-C17 & $1.530(3)$ & $\mathrm{C} 2-\mathrm{Zr} 1-\mathrm{C} 31$ & $116.15(6)$ \\
\hline C18-C19 & $1.410(2)$ & C38-Zr1-C31 & $95.05(6)$ \\
\hline C18-C23 & $1.411(2)$ & C1-N1-C6 & $119.35(14)$ \\
\hline C19-C20 & $1.400(3)$ & C1-N1-Zr1 & $91.51(10)$ \\
\hline C19-C24 & $1.522(3)$ & C6-N1-Zr1 & $146.55(12)$ \\
\hline C20-C21 & $1.375(3)$ & C2-N2-C18 & $121.09(13)$ \\
\hline C21-C22 & $1.381(3)$ & C2-N2-Zr1 & $92.52(10)$ \\
\hline C22-C23 & $1.397(2)$ & C18-N2-Zr1 & $145.48(11)$ \\
\hline C23-C27 & $1.516(2)$ & $\mathrm{C} 2-\mathrm{C} 1-\mathrm{N} 1$ & $120.59(15)$ \\
\hline C24-C26 & $1.528(3)$ & $\mathrm{C} 2-\mathrm{C} 1-\mathrm{C} 3$ & $121.01(16)$ \\
\hline $\mathrm{C} 24-\mathrm{C} 25$ & $1.532(4)$ & $\mathrm{N} 1-\mathrm{C} 1-\mathrm{C} 3$ & $117.72(15)$ \\
\hline C27-C28 & $1.530(3)$ & $\mathrm{C} 2-\mathrm{C} 1-\mathrm{Zr} 1$ & $75.40(10)$ \\
\hline C27-C29 & $1.530(3)$ & $\mathrm{N} 1-\mathrm{C} 1-\mathrm{Zr} 1$ & $53.96(8)$ \\
\hline C30-C31 & $1.474(3)$ & C3-C1-Zr1 & $139.63(13)$ \\
\hline C31-C36 & $1.400(3)$ & $\mathrm{C} 1-\mathrm{C} 2-\mathrm{N} 2$ & $119.70(15)$ \\
\hline C31-C32 & $1.416(3)$ & $\mathrm{C} 1-\mathrm{C} 2-\mathrm{C} 5$ & $120.70(16)$ \\
\hline C32-C33 & $1.380(4)$ & N2-C2-C5 & $118.72(16)$ \\
\hline C33-C34 & $1.372(4)$ & $\mathrm{C} 1-\mathrm{C} 2-\mathrm{Zr} 1$ & $72.98(10)$ \\
\hline C34-C35 & $1.390(4)$ & $\mathrm{N} 2-\mathrm{C} 2-\mathrm{Zr} 1$ & $53.86(8)$ \\
\hline C35-C36 & $1.375(3)$ & $\mathrm{C} 5-\mathrm{C} 2-\mathrm{Zr} 1$ & $142.35(14)$ \\
\hline C37-C38 & $1.459(3)$ & C11-C6-C7 & 119.91(17) \\
\hline C38-C43 & $1.404(3)$ & C11-C6-N1 & $119.85(16)$ \\
\hline C38-C39 & $1.406(3)$ & C7-C6-N1 & $120.24(17)$ \\
\hline C39-C40 & $1.369(4)$ & C8-C7-C6 & $118.25(19)$ \\
\hline C40-C41 & $1.385(4)$ & C8-C7-C12 & $118.70(18)$ \\
\hline C41-C42 & $1.363(4)$ & C6-C7-C12 & $122.98(17)$ \\
\hline \multirow[t]{2}{*}{$\mathrm{C} 42-\mathrm{C} 43$} & $1.395(4)$ & C9-C8-C7 & $122.0(2)$ \\
\hline & & C10-C9-C8 & $119.4(2)$ \\
\hline
\end{tabular}




\begin{tabular}{|c|c|}
\hline C9-C10-C11 & $121.5(2)$ \\
\hline C10-C11-C6 & 118.97(19) \\
\hline $\mathrm{C} 10-\mathrm{C} 11-\mathrm{C} 15$ & $118.54(18)$ \\
\hline C6-C11-C15 & $122.46(17)$ \\
\hline $\mathrm{C} 13-\mathrm{C} 12-\mathrm{C} 7$ & $111.18(18)$ \\
\hline C13-C12-C14 & $110.53(19)$ \\
\hline C7-C12-C14 & $112.84(18)$ \\
\hline C11-C15-C16 & $110.32(19)$ \\
\hline C11-C15-C17 & $112.28(18)$ \\
\hline C16-C15-C17 & $110.7(2)$ \\
\hline C19-C18-C23 & $119.68(15)$ \\
\hline C19-C18-N2 & $120.82(15)$ \\
\hline $\mathrm{C} 23-\mathrm{C} 18-\mathrm{N} 2$ & $119.45(15)$ \\
\hline C20-C19-C18 & $118.88(17)$ \\
\hline C20-C19-C24 & $117.56(17)$ \\
\hline C18-C19-C24 & $123.55(16)$ \\
\hline C21-C20-C19 & 121.64(19) \\
\hline C20-C21-C22 & $119.32(18)$ \\
\hline $\mathrm{C} 21-\mathrm{C} 22-\mathrm{C} 23$ & $121.53(18)$ \\
\hline C22-C23-C18 & $118.94(17)$ \\
\hline C22-C23-C27 & 118.78(16) \\
\hline C18-C23-C27 & $122.26(15)$ \\
\hline C19-C24-C26 & $110.8(2)$ \\
\hline C19-C24-C25 & $111.34(18)$ \\
\hline C26-C24-C25 & $110.5(2)$ \\
\hline C23-C27-C28 & $109.90(16)$ \\
\hline C23-C27-C29 & $112.65(16)$ \\
\hline C28-C27-C29 & $110.80(18)$ \\
\hline C31-C30-Zr1 & $95.17(13)$ \\
\hline C36-C31-C32 & $116.2(2)$ \\
\hline C36-C31-C30 & $122.34(19)$ \\
\hline C32-C31-C30 & $121.3(2)$ \\
\hline C36-C31-Zr1 & $116.17(13)$ \\
\hline C32-C31-Zr1 & $97.19(13)$ \\
\hline $\mathrm{C} 30-\mathrm{C} 31-\mathrm{Zr} 1$ & $53.59(10)$ \\
\hline C33-C32-C31 & $121.3(2)$ \\
\hline C34-C33-C32 & $120.8(2)$ \\
\hline C33-C34-C35 & $119.3(2)$ \\
\hline C36-C35-C34 & $120.1(2)$ \\
\hline C35-C36-C31 & $122.3(2)$ \\
\hline C38-C37-Zr1 & $86.91(11)$ \\
\hline C43-C38-C39 & $115.9(2)$ \\
\hline C43-C38-C37 & $120.49(19)$ \\
\hline C39-C38-C37 & $123.21(19)$ \\
\hline C43-C38-Zr1 & $85.90(12)$ \\
\hline C39-C38-Zr1 & $119.95(14)$ \\
\hline C37-C38-Zr1 & $59.87(10)$ \\
\hline C40-C39-C38 & 121.9(2) \\
\hline C39-C40-C41 & $121.0(2)$ \\
\hline C42-C41-C40 & $119.0(3)$ \\
\hline C41-C42-C43 & $120.5(2)$ \\
\hline C42-C43-C38 & $121.7(2)$ \\
\hline
\end{tabular}

DOW RESTRICTED - For internal use only 
Table 17. Anisotropic displacement parameters $\left(\AA^{2} \times 10^{3}\right)$ for 8 . The anisotropic displacement factor exponent takes the form: $-2 \pi^{2}\left[h^{2} a^{* 2} U^{11}+\ldots+2 h k a^{*} b^{*} U^{12}\right]$

\begin{tabular}{|c|c|c|c|c|c|c|}
\hline & $\mathrm{U}^{11}$ & $\mathrm{U}^{22}$ & $\mathrm{U}^{33}$ & $\mathrm{U}^{23}$ & $\mathrm{U}^{13}$ & $\mathrm{U}^{12}$ \\
\hline $\mathrm{Zr} 1$ & $28(1)$ & $31(1)$ & $32(1)$ & $-1(1)$ & $6(1)$ & $0(1)$ \\
\hline N1 & $30(1)$ & $37(1)$ & $29(1)$ & $0(1)$ & $5(1)$ & $-4(1)$ \\
\hline N2 & $33(1)$ & $33(1)$ & $28(1)$ & $-2(1)$ & $4(1)$ & $0(1)$ \\
\hline $\mathrm{C} 1$ & $36(1)$ & $38(1)$ & $30(1)$ & $0(1)$ & $8(1)$ & $-2(1)$ \\
\hline $\mathrm{C} 2$ & $36(1)$ & $33(1)$ & $33(1)$ & 1(1) & $8(1)$ & $0(1)$ \\
\hline C3 & $64(1)$ & $60(1)$ & $30(1)$ & $2(1)$ & $10(1)$ & $-20(1)$ \\
\hline C5 & $56(1)$ & $46(1)$ & $44(1)$ & $2(1)$ & $10(1)$ & $-15(1)$ \\
\hline C6 & $34(1)$ & $45(1)$ & $26(1)$ & $2(1)$ & $4(1)$ & $-7(1)$ \\
\hline C7 & $43(1)$ & $46(1)$ & $31(1)$ & 1(1) & $6(1)$ & $-8(1)$ \\
\hline C8 & $55(1)$ & $57(1)$ & $42(1)$ & $-8(1)$ & $2(1)$ & $-15(1)$ \\
\hline C9 & $44(1)$ & $78(2)$ & $51(1)$ & $-8(1)$ & $-9(1)$ & $-14(1)$ \\
\hline C10 & $38(1)$ & $69(1)$ & $48(1)$ & $-3(1)$ & $-4(1)$ & 1(1) \\
\hline C11 & $35(1)$ & $54(1)$ & $32(1)$ & $0(1)$ & $2(1)$ & $-2(1)$ \\
\hline C12 & $51(1)$ & $41(1)$ & $37(1)$ & $-3(1)$ & $10(1)$ & $-7(1)$ \\
\hline C13 & $86(2)$ & $79(2)$ & $61(2)$ & $5(1)$ & $38(2)$ & $7(2)$ \\
\hline C14 & $76(2)$ & $45(1)$ & $75(2)$ & $6(1)$ & $16(1)$ & $-7(1)$ \\
\hline C15 & $38(1)$ & $55(1)$ & $40(1)$ & $-4(1)$ & 1(1) & $6(1)$ \\
\hline C16 & $54(2)$ & $104(2)$ & $71(2)$ & $-35(2)$ & $23(1)$ & $-22(1)$ \\
\hline C17 & $124(3)$ & $65(2)$ & $62(2)$ & $1(1)$ & $-13(2)$ & $24(2)$ \\
\hline C18 & $36(1)$ & $31(1)$ & $32(1)$ & $-2(1)$ & $5(1)$ & $-1(1)$ \\
\hline C19 & $35(1)$ & $42(1)$ & $39(1)$ & $-6(1)$ & $5(1)$ & $0(1)$ \\
\hline $\mathrm{C} 20$ & $38(1)$ & $51(1)$ & $45(1)$ & $-11(1)$ & $2(1)$ & $-5(1)$ \\
\hline C21 & $47(1)$ & $53(1)$ & $45(1)$ & $-20(1)$ & $6(1)$ & $-7(1)$ \\
\hline C22 & $45(1)$ & $45(1)$ & $46(1)$ & $-14(1)$ & $12(1)$ & $-1(1)$ \\
\hline $\mathrm{C} 23$ & $37(1)$ & $34(1)$ & $34(1)$ & $-1(1)$ & $7(1)$ & $-1(1)$ \\
\hline C24 & $34(1)$ & $58(1)$ & $55(1)$ & $-20(1)$ & $0(1)$ & $6(1)$ \\
\hline $\mathrm{C} 25$ & $45(1)$ & $92(2)$ & $64(2)$ & $-19(1)$ & $17(1)$ & $-1(1)$ \\
\hline C26 & $48(1)$ & $64(1)$ & $81(2)$ & $-13(1)$ & $-8(1)$ & $13(1)$ \\
\hline $\mathrm{C} 27$ & $36(1)$ & $36(1)$ & $36(1)$ & $-3(1)$ & $5(1)$ & $3(1)$ \\
\hline C28 & $54(1)$ & $53(1)$ & $59(2)$ & $14(1)$ & 2(1) & $6(1)$ \\
\hline C29 & $42(1)$ & $68(1)$ & $46(1)$ & $-5(1)$ & 11(1) & $-1(1)$ \\
\hline C30 & $41(1)$ & $50(1)$ & $58(1)$ & $-6(1)$ & $20(1)$ & $3(1)$ \\
\hline C31 & $40(1)$ & $45(1)$ & $57(1)$ & $-11(1)$ & 21(1) & $3(1)$ \\
\hline C32 & $50(1)$ & $50(1)$ & $69(2)$ & $-10(1)$ & $16(1)$ & $-6(1)$ \\
\hline C33 & $78(2)$ & $44(1)$ & $80(2)$ & $-6(1)$ & $21(1)$ & $-7(1)$ \\
\hline C34 & $80(2)$ & $54(1)$ & $69(2)$ & $3(1)$ & $12(1)$ & $11(1)$ \\
\hline C35 & $58(1)$ & $62(1)$ & $66(2)$ & $-10(1)$ & 7(1) & $4(1)$ \\
\hline C36 & $47(1)$ & $47(1)$ & $62(1)$ & $-11(1)$ & $15(1)$ & $-1(1)$ \\
\hline C37 & $45(1)$ & $52(1)$ & $47(1)$ & $7(1)$ & $10(1)$ & $-11(1)$ \\
\hline C38 & $39(1)$ & $45(1)$ & $42(1)$ & $9(1)$ & $15(1)$ & $1(1)$ \\
\hline C39 & $60(1)$ & $55(1)$ & $52(1)$ & $4(1)$ & $14(1)$ & $18(1)$ \\
\hline C40 & $54(1)$ & $94(2)$ & $57(2)$ & $7(1)$ & $5(1)$ & $22(1)$ \\
\hline C41 & $72(2)$ & $92(2)$ & $49(2)$ & $-5(1)$ & $4(1)$ & $-7(1)$ \\
\hline C42 & $102(2)$ & $59(1)$ & $54(1)$ & $-8(1)$ & $24(1)$ & $4(1)$ \\
\hline C43 & $66(2)$ & $51(1)$ & $48(1)$ & $9(1)$ & 19(1) & 19(1) \\
\hline
\end{tabular}


Table 18. Hydrogen coordinates ( x 10 ${ }^{4}$ ) and isotropic displacement parameters $\left(\AA^{2} \times 10^{3}\right)$ for 8 .

\begin{tabular}{|c|c|c|c|c|}
\hline & $\mathrm{x}$ & $\mathrm{y}$ & $\mathrm{z}$ & $\mathrm{U}(\mathrm{eq})$ \\
\hline H3A & 7527 & 6657 & 3347 & 77 \\
\hline H3B & 7010 & 7838 & 3371 & 77 \\
\hline $\mathrm{H} 3 \mathrm{C}$ & 6667 & 6470 & 3210 & 77 \\
\hline H5A & 7828 & 8885 & 4142 & 73 \\
\hline H5B & 8523 & 8014 & 4402 & 73 \\
\hline H5C & 8284 & 8987 & 4938 & 73 \\
\hline H8 & 5270 & 2998 & 3023 & 63 \\
\hline H9 & 4287 & 4372 & 2842 & 73 \\
\hline H10 & 4398 & 6310 & 3413 & 64 \\
\hline H12 & 7008 & 3441 & 4183 & 52 \\
\hline H13A & 7134 & 4055 & 3053 & 108 \\
\hline H13B & 6598 & 2962 & 2699 & 108 \\
\hline H13C & 7372 & 2621 & 3183 & 108 \\
\hline H14A & 6836 & 1282 & 4001 & 98 \\
\hline H14B & 6051 & 1508 & 3508 & 98 \\
\hline $\mathrm{H} 14 \mathrm{C}$ & 6191 & 1816 & 4335 & 98 \\
\hline H15 & 6001 & 7551 & 4566 & 55 \\
\hline H16A & 5182 & 6640 & 5203 & 112 \\
\hline H16B & 4513 & 7234 & 4652 & 112 \\
\hline H16C & 5081 & 8128 & 5153 & 112 \\
\hline H17A & 4731 & 8399 & 3579 & 133 \\
\hline H17B & 5534 & 8491 & 3436 & 133 \\
\hline $\mathrm{H} 17 \mathrm{C}$ & 5319 & 9288 & 4061 & 133 \\
\hline $\mathrm{H} 20$ & 9494 & 8899 & 7178 & 55 \\
\hline $\mathrm{H} 21$ & 8656 & 10149 & 7584 & 58 \\
\hline $\mathrm{H} 22$ & 7427 & 10028 & 7040 & 54 \\
\hline $\mathrm{H} 24$ & 9136 & 6714 & 5733 & 61 \\
\hline $\mathrm{H} 25 \mathrm{~A}$ & 10148 & 8689 & 6253 & 100 \\
\hline $\mathrm{H} 25 \mathrm{~B}$ & 9645 & 8651 & 5476 & 100 \\
\hline $\mathrm{H} 25 \mathrm{C}$ & 10276 & 7637 & 5703 & 100 \\
\hline $\mathrm{H} 26 \mathrm{~A}$ & 9448 & 5786 & 6854 & 101 \\
\hline H26B & 9983 & 6918 & 7150 & 101 \\
\hline $\mathrm{H} 26 \mathrm{C}$ & 10179 & 5979 & 6574 & 101 \\
\hline $\mathrm{H} 27$ & 6607 & 7864 & 5684 & 44 \\
\hline $\mathrm{H} 28 \mathrm{~A}$ & 6758 & 9740 & 5100 & 85 \\
\hline $\mathrm{H} 28 \mathrm{~B}$ & 6618 & 10553 & 5753 & 85 \\
\hline $\mathrm{H} 28 \mathrm{C}$ & 5971 & 9760 & 5284 & 85 \\
\hline H29A & 6290 & 9358 & 6815 & 77 \\
\hline H29B & 6377 & 7866 & 6851 & 77 \\
\hline $\mathrm{H} 29 \mathrm{C}$ & 5719 & 8489 & 6300 & 77 \\
\hline H30A & 8289 & 4286 & 4110 & 58 \\
\hline H30B & 8829 & 5344 & 4536 & 58 \\
\hline H32 & 8101 & 2264 & 4815 & 67 \\
\hline H33 & 8643 & 781 & 5643 & 80 \\
\hline H34 & 9740 & 1213 & 6425 & 82 \\
\hline H35 & 10288 & 3191 & 6393 & 76 \\
\hline H36 & 9747 & 4693 & 5582 & 62 \\
\hline H37A & 6496 & 3822 & 5674 & 58 \\
\hline H37B & 7102 & 2771 & 5591 & 58 \\
\hline H39 & 8101 & 2447 & 6645 & 66 \\
\hline $\mathrm{H} 40$ & 8830 & 3136 & 7690 & 83 \\
\hline
\end{tabular}


H41

$\mathrm{H} 42$

H43
8703

7829

7056
5168

6501

5804
8113

7468

6427
87

85

DOW RESTRICTED - For internal use only 
Table 19. Crystal data and structure refinement for $\mathbf{1 3}$.

Empirical formula

Formula weight

Temperature

Wavelength

Crystal system

Space group

Unit cell dimensions

Volume

$\mathrm{Z}$

Density (calculated)

Absorption coefficient

$\mathrm{F}(000)$

Crystal size

Theta range for data collection

Index ranges

Reflections collected

Independent reflections

Completeness to theta $=27.50^{\circ}$

Refinement method

Data / restraints / parameters

Goodness-of-fit on $\mathrm{F}^{2}$

Final $\mathrm{R}$ indices [I $>2 \operatorname{sigma}(\mathrm{I})]$

$\mathrm{R}$ indices (all data)

Largest diff. peak and hole
$\mathrm{C}_{54} \mathrm{H}_{64} \mathrm{~N}_{2} \mathrm{Zr}$

832.29

223(2) K

$0.71073 \AA$

Monoclinic

$\mathrm{P} 21 / \mathrm{n}$

$\mathrm{a}=13.5237(10) \AA$

$\alpha=90^{\circ}$

$\mathrm{b}=18.2574(14) \AA$

$\beta=91.016(2)^{\circ}$

$c=18.3733(14) \AA$

$\gamma=90^{\circ}$

4535.8(6) $\AA^{3}$

4

$1.219 \mathrm{Mg} / \mathrm{m}^{3}$

$0.280 \mathrm{~mm}^{-1}$

1768

$0.40 \times 0.36 \times 0.32 \mathrm{~mm}^{3}$

1.57 to $27.50^{\circ}$

$-17<=\mathrm{h}<=17,-23<=\mathrm{k}<=23,-23<=\mathrm{l}<=23$

30152

$10186[\mathrm{R}(\mathrm{int})=0.0431]$

$97.7 \%$

Full-matrix least-squares on $\mathrm{F}^{2}$

$10186 / 0$ / 522

1.038

$\mathrm{R} 1=0.0409, \mathrm{wR} 2=0.1081$ [8458]

$\mathrm{R} 1=0.0508, \mathrm{wR} 2=0.1170$

0.341 and -0.400 e. $\AA^{-3}$

$\mathrm{R} 1=\sum\left(\left\|\mathrm{F}_{\mathrm{O}}|-| \mathrm{F}_{\mathrm{C}}\right\|\right) / \sum\left|\mathrm{F}_{\mathrm{O}}\right|$

$\mathrm{wR} 2=\left[\sum\left[\mathrm{w}\left(\mathrm{F}_{\mathrm{O}}{ }^{2}-\mathrm{F}_{\mathrm{c}}{ }^{2}\right)^{2}\right] / \sum\left[\mathrm{w}\left(\mathrm{F}_{\mathrm{O}}{ }^{2}\right)^{2}\right]\right]^{1 / 2}$

$\mathrm{S}=\left[\sum\left[\mathrm{w}\left(\mathrm{F}_{\mathrm{O}}{ }^{2}-\mathrm{F}_{\mathrm{c}}{ }^{2}\right)^{2}\right] /(\mathrm{n}-\mathrm{p})\right]^{1 / 2}$

$\mathrm{w}=1 /\left[\sigma^{2}\left(\mathrm{~F}_{\mathrm{O}}{ }^{2}\right)+\left(\mathrm{m}^{*} \mathrm{p}\right)^{2}+\mathrm{n} * \mathrm{p}\right], \mathrm{p}=\left[\max \left(\mathrm{F}_{\mathrm{O}}{ }^{2}, 0\right)+2 * \mathrm{~F}_{\mathrm{c}}{ }^{2}\right] / 3, \mathrm{~m} \& \mathrm{n}$ are constants. 
Table 20. Atomic coordinates ( x 10 $0^{4}$ ) and equivalent isotropic displacement parameters $\left(\AA^{2} \times 10^{3}\right)$ for 13. $U(e q)$ is defined as one third of the trace of the orthogonalized $U^{i j}$ tensor.

\begin{tabular}{|c|c|c|c|c|}
\hline & $\mathrm{x}$ & $\mathrm{y}$ & $\mathrm{z}$ & $\mathrm{U}(\mathrm{eq})$ \\
\hline$\overline{\mathrm{Zr}}$ & $3(1)$ & $-2244(1)$ & $-7775(1)$ & $29(1)$ \\
\hline N1 & $-1336(1)$ & $-3044(1)$ & $-7412(1)$ & $29(1)$ \\
\hline $\mathrm{N} 2$ & 580(1) & $-3268(1)$ & $-7424(1)$ & $29(1)$ \\
\hline $\mathrm{C} 1$ & $-1077(1)$ & $-3645(1)$ & $-7098(1)$ & $32(1)$ \\
\hline $\mathrm{C} 2$ & $2(1)$ & $-3795(1)$ & $-7019(1)$ & $31(1)$ \\
\hline $\mathrm{C} 3$ & $-1804(2)$ & $-4232(1)$ & $-6876(1)$ & $50(1)$ \\
\hline C6 & $-2397(1)$ & $-2953(1)$ & $-7562(1)$ & $32(1)$ \\
\hline $\mathrm{C} 7$ & $-2990(1)$ & $-2574(1)$ & $-7075(1)$ & $36(1)$ \\
\hline $\mathrm{C} 8$ & $-3996(2)$ & $-2516(1)$ & $-7246(1)$ & $45(1)$ \\
\hline C9 & $-4393(2)$ & $-2814(1)$ & $-7878(2)$ & $49(1)$ \\
\hline C10 & $-3791(2)$ & $-3175(1)$ & $-8356(1)$ & $46(1)$ \\
\hline C11 & $-2782(2)$ & $-3254(1)$ & $-8214(1)$ & $38(1)$ \\
\hline C12 & $-2602(2)$ & $-2238(1)$ & $-6366(1)$ & $41(1)$ \\
\hline C13 & $-2931(2)$ & $-2679(2)$ & $-5710(2)$ & $63(1)$ \\
\hline C14 & $-2936(2)$ & $-1440(2)$ & $-6276(2)$ & $58(1)$ \\
\hline C15 & $-2147(2)$ & $-3643(1)$ & $-8768(1)$ & $47(1)$ \\
\hline C16 & $-2596(3)$ & $-4379(2)$ & $-9008(2)$ & $89(1)$ \\
\hline $\mathrm{C} 17$ & $-1984(3)$ & $-3162(2)$ & $-9430(2)$ & $85(1)$ \\
\hline C18 & 1519(1) & $-3575(1)$ & $-7638(1)$ & $30(1)$ \\
\hline C19 & 2403(1) & $-3416(1)$ & $-7249(1)$ & $33(1)$ \\
\hline $\mathrm{C} 20$ & $3284(2)$ & $-3730(1)$ & $-7474(1)$ & $43(1)$ \\
\hline $\mathrm{C} 21$ & $3319(2)$ & $-4201(1)$ & $-8058(1)$ & $53(1)$ \\
\hline $\mathrm{C} 22$ & $2459(2)$ & $-4367(1)$ & $-8431(1)$ & $49(1)$ \\
\hline $\mathrm{C} 23$ & $1557(2)$ & $-4067(1)$ & $-8237(1)$ & $38(1)$ \\
\hline $\mathrm{C} 24$ & $2431(2)$ & $-2954(1)$ & $-6563(1)$ & $38(1)$ \\
\hline $\mathrm{C} 25$ & $2649(2)$ & $-3432(2)$ & $-5898(1)$ & $66(1)$ \\
\hline $\mathrm{C} 26$ & $3177(2)$ & $-2326(2)$ & $-6594(2)$ & $58(1)$ \\
\hline $\mathrm{C} 27$ & $636(2)$ & $-4295(1)$ & $-8671(1)$ & $48(1)$ \\
\hline $\mathrm{C} 28$ & $361(2)$ & $-5097(2)$ & $-8522(2)$ & $72(1)$ \\
\hline $\mathrm{C} 29$ & $752(2)$ & $-4190(2)$ & $-9495(1)$ & $66(1)$ \\
\hline $\mathrm{C} 30$ & $-1393(2)$ & $-1536(1)$ & $-7968(1)$ & $44(1)$ \\
\hline C31 & 691(2) & $-1478(1)$ & $-6926(1)$ & $38(1)$ \\
\hline $\mathrm{C} 32$ & $599(2)$ & $-2173(1)$ & $-8907(1)$ & $49(1)$ \\
\hline C33 & $-1442(1)$ & $-4816(1)$ & $-6363(1)$ & $36(1)$ \\
\hline C34 & $-1234(2)$ & $-5514(1)$ & $-6611(1)$ & $51(1)$ \\
\hline $\mathrm{C} 35$ & $-973(2)$ & $-6071(1)$ & $-6118(2)$ & $60(1)$ \\
\hline C36 & $-921(2)$ & $-5914(2)$ & $-5390(2)$ & $61(1)$ \\
\hline $\mathrm{C} 37$ & $-1123(2)$ & $-5229(2)$ & $-5141(2)$ & $59(1)$ \\
\hline C38 & $-1378(2)$ & $-4688(1)$ & $-5620(1)$ & $47(1)$ \\
\hline C39 & $-1181(1)$ & $-832(1)$ & $-8333(1)$ & $36(1)$ \\
\hline $\mathrm{C} 40$ & $-1278(2)$ & $-761(1)$ & $-9090(1)$ & $45(1)$ \\
\hline $\mathrm{C} 41$ & $-1067(2)$ & $-124(2)$ & $-9445(2)$ & $63(1)$ \\
\hline $\mathrm{C} 42$ & $-747(2)$ & $476(2)$ & $-9068(2)$ & $72(1)$ \\
\hline $\mathrm{C} 43$ & $-664(2)$ & $441(2)$ & $-8316(2)$ & $68(1)$ \\
\hline $\mathrm{C} 44$ & $-885(2)$ & $-210(1)$ & $-7949(1)$ & $49(1)$ \\
\hline $\mathrm{C} 45$ & $209(2)$ & $-1496(1)$ & $-6203(1)$ & $37(1)$ \\
\hline $\mathrm{C} 46$ & $107(2)$ & $-2146(1)$ & $-5809(1)$ & $43(1)$ \\
\hline $\mathrm{C} 47$ & $-359(2)$ & $-2169(1)$ & $-5145(1)$ & $51(1)$ \\
\hline $\mathrm{C} 48$ & $-747(2)$ & $-1538(2)$ & $-4844(1)$ & $54(1)$ \\
\hline C49 & $-656(2)$ & $-888(2)$ & $-5221(1)$ & $59(1)$ \\
\hline $\mathrm{C} 50$ & $-195(2)$ & $-870(1)$ & $-5886(1)$ & $50(1)$ \\
\hline
\end{tabular}




\begin{tabular}{lrrrr} 
C51 & $1497(2)$ & $-1731(1)$ & $-8762(1)$ & $41(1)$ \\
C52 & $2427(2)$ & $-2055(2)$ & $-8677(1)$ & $55(1)$ \\
C54 & $3186(2)$ & $-899(2)$ & $-8429(2)$ & $74(1)$ \\
C53 & $3255(2)$ & $-1642(2)$ & $-8528(2)$ & $73(1)$ \\
C55 & $2272(3)$ & $-565(2)$ & $-8494(2)$ & $72(1)$ \\
C56 & $1436(2)$ & $-971(1)$ & $-8673(1)$ & $53(1)$ \\
\hline
\end{tabular}

Table 21. Bond lengths $[\AA]$ and angles $\left[{ }^{\circ}\right]$ for $\mathbf{1 3}$.

\begin{tabular}{|c|c|c|c|}
\hline $\mathrm{Zr}-\mathrm{N} 2$ & $2.121(2)$ & C16-H16B & 0.9700 \\
\hline Zr-C32 & $2.247(2)$ & C16-H16C & 0.9700 \\
\hline Zr-C31 & $2.283(2)$ & C17-H17A & 0.9700 \\
\hline Zr-C30 & $2.310(2)$ & C17-H17B & 0.9700 \\
\hline Zr-N1 & $2.429(2)$ & C17-H18C & 0.9700 \\
\hline N1-C1 & $1.286(2)$ & C18-C19 & $1.413(2)$ \\
\hline N1-C6 & $1.466(2)$ & C18-C23 & $1.422(3)$ \\
\hline N2-C18 & $1.449(2)$ & C19-C20 & $1.391(3)$ \\
\hline N2-C2 & $1.453(2)$ & C19-C24 & $1.516(3)$ \\
\hline $\mathrm{C} 1-\mathrm{C} 2$ & $1.488(2)$ & C20-C21 & $1.375(3)$ \\
\hline C1-C3 & $1.515(3)$ & C20-H20 & 0.9400 \\
\hline C2-H2A & 0.9800 & C21-C22 & $1.373(4)$ \\
\hline C2-H2B & 0.9800 & $\mathrm{C} 21-\mathrm{H} 21$ & 0.9400 \\
\hline C3-C33 & $1.499(3)$ & C22-C23 & $1.390(3)$ \\
\hline C3-H3A & 0.9800 & $\mathrm{C} 22-\mathrm{H} 22$ & 0.9400 \\
\hline C3-H3B & 0.9800 & C23-C27 & $1.524(3)$ \\
\hline C6-C7 & $1.396(3)$ & C24-C25 & $1.527(3)$ \\
\hline C6-C11 & $1.408(3)$ & C24-C26 & $1.529(3)$ \\
\hline C7-C8 & $1.394(3)$ & C24-H24 & 0.9900 \\
\hline C7-C12 & $1.525(3)$ & $\mathrm{C} 25-\mathrm{H} 25 \mathrm{~A}$ & 0.9700 \\
\hline C8-C9 & $1.383(4)$ & $\mathrm{C} 25-\mathrm{H} 25 \mathrm{~B}$ & 0.9700 \\
\hline C8-H8 & 0.9400 & $\mathrm{C} 25-\mathrm{H} 25 \mathrm{C}$ & 0.9700 \\
\hline C9-C10 & $1.376(4)$ & C26-H26A & 0.9700 \\
\hline C9-H9 & 0.9400 & C26-H26B & 0.9700 \\
\hline C10-C11 & $1.392(3)$ & $\mathrm{C} 26-\mathrm{H} 26 \mathrm{C}$ & 0.9700 \\
\hline C10-H10 & 0.9400 & C27-C28 & $1.537(4)$ \\
\hline C11-C15 & $1.520(3)$ & C27-C29 & $1.537(4)$ \\
\hline C12-C13 & $1.523(3)$ & $\mathrm{C} 27-\mathrm{H} 27$ & 0.9900 \\
\hline C12-C14 & $1.535(3)$ & C28-H28A & 0.9700 \\
\hline C12-H12 & 0.9900 & $\mathrm{C} 28-\mathrm{H} 28 \mathrm{~B}$ & 0.9700 \\
\hline C13-H13A & 0.9700 & $\mathrm{C} 28-\mathrm{H} 28 \mathrm{C}$ & 0.9700 \\
\hline C13-H13B & 0.9700 & C29-H29A & 0.9700 \\
\hline C13-H13C & 0.9700 & C29-H29B & 0.9700 \\
\hline C14-H14A & 0.9700 & C29-H29C & 0.9700 \\
\hline C14-H14B & 0.9700 & C30-C39 & $1.481(3)$ \\
\hline C14-H14C & 0.9700 & C30-H30A & 0.9800 \\
\hline C15-C17 & $1.520(4)$ & C30-H30B & 0.9800 \\
\hline C15-C16 & $1.537(4)$ & C31-C45 & $1.490(3)$ \\
\hline C15-H15 & 0.9900 & C31-H31A & 0.9800 \\
\hline C16-H16A & 0.9700 & C31-H31B & 0.9800 \\
\hline
\end{tabular}




\begin{tabular}{|c|c|}
\hline C32-C51 & $1.479(3)$ \\
\hline C32-H32A & 0.9800 \\
\hline C32-H32B & 0.9800 \\
\hline C33-C34 & $1.385(3)$ \\
\hline C33-C38 & $1.387(3)$ \\
\hline C34-C35 & $1.403(4)$ \\
\hline C34-H34 & 0.9400 \\
\hline C35-C36 & $1.368(4)$ \\
\hline C35-H35 & 0.9400 \\
\hline C36-C37 & $1.359(4)$ \\
\hline C36-H36 & 0.9400 \\
\hline C37-C38 & $1.363(3)$ \\
\hline C37-H37 & 0.9400 \\
\hline C38-H38 & 0.9400 \\
\hline C39-C44 & $1.392(3)$ \\
\hline C39-C40 & $1.401(3)$ \\
\hline C40-C41 & $1.367(4)$ \\
\hline C40-H40 & 0.9400 \\
\hline C41-C42 & $1.362(5)$ \\
\hline C41-H41 & 0.9400 \\
\hline C42-C43 & $1.385(5)$ \\
\hline C42-H42 & 0.9400 \\
\hline C43-C44 & $1.402(4)$ \\
\hline C43-H43 & 0.9400 \\
\hline C44-H44 & 0.9400 \\
\hline C45-C50 & $1.399(3)$ \\
\hline $\mathrm{C} 45-\mathrm{C} 46$ & $1.399(3)$ \\
\hline C46-C47 & $1.384(3)$ \\
\hline C46-H46 & 0.9400 \\
\hline C47-C48 & $1.385(4)$ \\
\hline C47-H47 & 0.9400 \\
\hline C48-C49 & $1.380(4)$ \\
\hline C48-H48 & 0.9400 \\
\hline C49-C50 & $1.382(4)$ \\
\hline C49-H49 & 0.9400 \\
\hline C50-H50 & 0.9400 \\
\hline C51-C52 & $1.396(3)$ \\
\hline C51-C56 & $1.400(3)$ \\
\hline C52-C53 & $1.373(4)$ \\
\hline C52-H52 & 0.9400 \\
\hline C54-C53 & $1.373(5)$ \\
\hline C54-C55 & $1.381(5)$ \\
\hline C54-H53 & 0.9400 \\
\hline C53-H53 & 0.9400 \\
\hline C55-C56 & $1.386(4)$ \\
\hline C55-H54 & 0.9400 \\
\hline C56-H55 & 0.9400 \\
\hline N2-Zr-C32 & $101.34(8)$ \\
\hline N2-Zr-C31 & $100.88(7)$ \\
\hline C32-Zr-C31 & $116.68(9)$ \\
\hline N2-Zr-C30 & $146.59(7)$ \\
\hline C32-Zr-C30 & $97.52(9)$ \\
\hline C31-Zr-C30 & $94.82(8)$ \\
\hline N2-Zr-N1 & $70.05(5)$ \\
\hline C32-Zr-N1 & $124.77(7)$ \\
\hline
\end{tabular}

\begin{tabular}{|c|c|}
\hline C31-Zr-N1 & $118.52(7)$ \\
\hline C30-Zr-N1 & $76.54(7)$ \\
\hline C1-N1-C6 & $116.08(16)$ \\
\hline $\mathrm{C} 1-\mathrm{N} 1-\mathrm{Zr}$ & $115.94(12)$ \\
\hline C6-N1-Zr & $127.75(12)$ \\
\hline C18-N2-C2 & $111.33(15)$ \\
\hline C18-N2-Zr & $125.33(12)$ \\
\hline $\mathrm{C} 2-\mathrm{N} 2-\mathrm{Zr}$ & $122.77(11)$ \\
\hline $\mathrm{N} 1-\mathrm{C} 1-\mathrm{C} 2$ & $117.38(17)$ \\
\hline $\mathrm{N} 1-\mathrm{C} 1-\mathrm{C} 3$ & $123.43(17)$ \\
\hline $\mathrm{C} 2-\mathrm{C} 1-\mathrm{C} 3$ & $118.90(17)$ \\
\hline $\mathrm{N} 2-\mathrm{C} 2-\mathrm{C} 1$ & $111.31(15)$ \\
\hline N2-C2-H2A & 109.4 \\
\hline C1-C2-H2A & 109.4 \\
\hline N2-C2-H2B & 109.4 \\
\hline C1-C2-H2B & 109.4 \\
\hline H2A-C2-H2B & 108.0 \\
\hline C33-C3-C1 & $117.74(17)$ \\
\hline C33-C3-H3A & 107.9 \\
\hline C1-C3-H3A & 107.9 \\
\hline C33-C3-H3B & 107.9 \\
\hline C1-C3-H3B & 107.9 \\
\hline H3A-C3-H3B & 107.2 \\
\hline C7-C6-C11 & $122.07(17)$ \\
\hline C7-C6-N1 & $120.43(17)$ \\
\hline C11-C6-N1 & $117.49(18)$ \\
\hline C8-C7-C6 & $117.5(2)$ \\
\hline C8-C7-C12 & $118.8(2)$ \\
\hline C6-C7-C12 & $123.68(17)$ \\
\hline C9-C8-C7 & $121.5(2)$ \\
\hline C9-C8-H8 & 119.2 \\
\hline C7-C8-H8 & 119.2 \\
\hline C10-C9-C8 & $119.90(19)$ \\
\hline С10-C9-H9 & 120.0 \\
\hline C8-C9-H9 & 120.0 \\
\hline C9-C10-C11 & $121.3(2)$ \\
\hline C9-C10-H10 & 119.4 \\
\hline C11-C10-H10 & 119.4 \\
\hline C10-C11-C6 & $117.7(2)$ \\
\hline C10-C11-C15 & $119.12(19)$ \\
\hline C6-C11-C15 & $123.15(18)$ \\
\hline C13-C12-C7 & $111.3(2)$ \\
\hline C13-C12-C14 & $109.0(2)$ \\
\hline C7-C12-C14 & $112.16(19)$ \\
\hline C13-C12-H12 & 108.1 \\
\hline C7-C12-H12 & 108.1 \\
\hline C14-C12-H12 & 108.1 \\
\hline C12-C13-H13A & 109.5 \\
\hline C12-C13-H13B & 109.5 \\
\hline H13A-C13-H13B & 109.5 \\
\hline C12-C13-H13C & 109.5 \\
\hline H13A-C13-H13C & 109.5 \\
\hline H13B-C13-H13C & 109.5 \\
\hline C12-C14-H14A & 109.5 \\
\hline C12-C14-H14B & 109.5 \\
\hline H14A-C14-H14B & 109.5 \\
\hline
\end{tabular}




\begin{tabular}{|c|c|}
\hline C12-C14-H14C & 109.5 \\
\hline H14A-C14-H14C & 109.5 \\
\hline H14B-C14-H14C & 109.5 \\
\hline C11-C15-C17 & $111.0(2)$ \\
\hline C11-C15-C16 & $112.1(2)$ \\
\hline C17-C15-C16 & $109.7(2)$ \\
\hline C11-C15-H15 & 108.0 \\
\hline C17-C15-H15 & 108.0 \\
\hline C16-C15-H15 & 108.0 \\
\hline C15-C16-H16A & 109.5 \\
\hline C15-C16-H16B & 109.5 \\
\hline H16A-C16-H16B & 109.5 \\
\hline C15-C16-H16C & 109.5 \\
\hline H16A-C16-H16C & 109.5 \\
\hline H16B-C16-H16C & 109.5 \\
\hline C15-C17-H17A & 109.5 \\
\hline C15-C17-H17B & 109.5 \\
\hline H17A-C17-H17B & 109.5 \\
\hline C15-C17-H18C & 109.5 \\
\hline H17A-C17-H18C & 109.5 \\
\hline H17B-C17-H18C & 109.5 \\
\hline C19-C18-C23 & $118.68(17)$ \\
\hline C19-C18-N2 & $121.42(17)$ \\
\hline C23-C18-N2 & $119.88(16)$ \\
\hline C20-C19-C18 & 119.09(19) \\
\hline C20-C19-C24 & $117.89(17)$ \\
\hline C18-C19-C24 & $122.92(17)$ \\
\hline C21-C20-C19 & $122.0(2)$ \\
\hline C21-C20-H20 & 119.0 \\
\hline C19-C20-H20 & 119.0 \\
\hline $\mathrm{C} 22-\mathrm{C} 21-\mathrm{C} 20$ & $119.2(2)$ \\
\hline C22-C21-H21 & 120.4 \\
\hline C20-C21-H21 & 120.4 \\
\hline $\mathrm{C} 21-\mathrm{C} 22-\mathrm{C} 23$ & $121.6(2)$ \\
\hline $\mathrm{C} 21-\mathrm{C} 22-\mathrm{H} 22$ & 119.2 \\
\hline $\mathrm{C} 23-\mathrm{C} 22-\mathrm{H} 22$ & 119.2 \\
\hline $\mathrm{C} 22-\mathrm{C} 23-\mathrm{C} 18$ & 119.41(19) \\
\hline $\mathrm{C} 22-\mathrm{C} 23-\mathrm{C} 27$ & $118.1(2)$ \\
\hline C18-C23-C27 & $122.49(18)$ \\
\hline C19-C24-C25 & $110.4(2)$ \\
\hline C19-C24-C26 & 113.19(19) \\
\hline $\mathrm{C} 25-\mathrm{C} 24-\mathrm{C} 26$ & $110.0(2)$ \\
\hline C19-C24-H24 & 107.7 \\
\hline C25-C24-H24 & 107.7 \\
\hline C26-C24-H24 & 107.7 \\
\hline $\mathrm{C} 24-\mathrm{C} 25-\mathrm{H} 25 \mathrm{~A}$ & 109.5 \\
\hline C24-C25-H25B & 109.5 \\
\hline $\mathrm{H} 25 \mathrm{~A}-\mathrm{C} 25-\mathrm{H} 25 \mathrm{~B}$ & 109.5 \\
\hline $\mathrm{C} 24-\mathrm{C} 25-\mathrm{H} 25 \mathrm{C}$ & 109.5 \\
\hline $\mathrm{H} 25 \mathrm{~A}-\mathrm{C} 25-\mathrm{H} 25 \mathrm{C}$ & 109.5 \\
\hline $\mathrm{H} 25 \mathrm{~B}-\mathrm{C} 25-\mathrm{H} 25 \mathrm{C}$ & 109.5 \\
\hline C24-C26-H26A & 109.5 \\
\hline C24-C26-H26B & 109.5 \\
\hline H26A-C26-H26B & 109.5 \\
\hline C24-C26-H26C & 109.5 \\
\hline $\mathrm{H} 26 \mathrm{~A}-\mathrm{C} 26-\mathrm{H} 26 \mathrm{C}$ & 109.5 \\
\hline
\end{tabular}

\begin{tabular}{|c|c|}
\hline $\mathrm{H} 26 \mathrm{~B}-\mathrm{C} 26-\mathrm{H} 26 \mathrm{C}$ & 109.5 \\
\hline C23-C27-C28 & $111.4(2)$ \\
\hline C23-C27-C29 & $112.6(2)$ \\
\hline C28-C27-C29 & $108.8(2)$ \\
\hline C23-C27-H27 & 107.9 \\
\hline C28-C27-H27 & 107.9 \\
\hline C29-C27-H27 & 107.9 \\
\hline C27-C28-H28A & 109.5 \\
\hline C27-C28-H28B & 109.5 \\
\hline H28A-C28-H28B & 109.5 \\
\hline $\mathrm{C} 27-\mathrm{C} 28-\mathrm{H} 28 \mathrm{C}$ & 109.5 \\
\hline H28A-C28-H28C & 109.5 \\
\hline $\mathrm{H} 28 \mathrm{~B}-\mathrm{C} 28-\mathrm{H} 28 \mathrm{C}$ & 109.5 \\
\hline C27-C29-H29A & 109.5 \\
\hline C27-C29-H29B & 109.5 \\
\hline H29A-C29-H29B & 109.5 \\
\hline C27-C29-H29C & 109.5 \\
\hline H29A-C29-H29C & 109.5 \\
\hline H29B-C29-H29C & 109.5 \\
\hline C39-C30-Zr & $113.03(14)$ \\
\hline С39-C30-H30A & 109.0 \\
\hline Zr-C30-H30A & 109.0 \\
\hline С39-С30-Н30B & 109.0 \\
\hline Zr-C30-H30B & 109.0 \\
\hline H30A-C30-H30B & 107.8 \\
\hline $\mathrm{C} 45-\mathrm{C} 31-\mathrm{Zr}$ & $114.57(13)$ \\
\hline C45-C31-H31A & 108.6 \\
\hline Zr-C31-H31A & 108.6 \\
\hline C45-C31-H31B & 108.6 \\
\hline Zr-C31-H31B & 108.6 \\
\hline H31A-C31-H31B & 107.6 \\
\hline $\mathrm{C} 51-\mathrm{C} 32-\mathrm{Zr}$ & $99.87(15)$ \\
\hline C51-C32-H32A & 111.8 \\
\hline $\mathrm{Zr}-\mathrm{C} 32-\mathrm{H} 32 \mathrm{~A}$ & 111.8 \\
\hline C51-C32-H32B & 111.8 \\
\hline Zr-C32-H32B & 111.8 \\
\hline H32A-C32-H32B & 109.5 \\
\hline C34-C33-C38 & $118.0(2)$ \\
\hline C34-C33-C3 & $120.9(2)$ \\
\hline C38-C33-C3 & $120.9(2)$ \\
\hline C33-C34-C35 & $120.3(2)$ \\
\hline C33-C34-H34 & 119.8 \\
\hline C35-C34-H34 & 119.8 \\
\hline C36-C35-C34 & $119.1(2)$ \\
\hline C36-C35-H35 & 120.4 \\
\hline C34-C35-H35 & 120.4 \\
\hline C37-C36-C35 & $121.0(2)$ \\
\hline C37-C36-H36 & 119.5 \\
\hline C35-C36-H36 & 119.5 \\
\hline C36-C37-C38 & $120.0(3)$ \\
\hline C36-C37-H37 & 120.0 \\
\hline C38-C37-H37 & 120.0 \\
\hline C37-C38-C33 & $121.6(2)$ \\
\hline C37-C38-H38 & 119.2 \\
\hline C33-C38-H38 & 119.2 \\
\hline C44-C39-C40 & $116.7(2)$ \\
\hline
\end{tabular}




\begin{tabular}{|c|c|}
\hline C44-C39-C30 & $122.4(2)$ \\
\hline С40-C39-С30 & $120.9(2)$ \\
\hline C41-C40-C39 & $122.4(2)$ \\
\hline C41-C40-H40 & 118.8 \\
\hline C39-C40-H40 & 118.8 \\
\hline C42-C41-C40 & $120.5(3)$ \\
\hline C42-C41-H41 & 119.7 \\
\hline C40-C41-H41 & 119.7 \\
\hline C41-C42-C43 & $119.4(3)$ \\
\hline C41-C42-H42 & 120.3 \\
\hline $\mathrm{C} 43-\mathrm{C} 42-\mathrm{H} 42$ & 120.3 \\
\hline C42-C43-C44 & $120.3(3)$ \\
\hline C42-C43-H43 & 119.9 \\
\hline C44-C43-H43 & 119.9 \\
\hline C39-C44-C43 & $120.6(2)$ \\
\hline C39-C44-H44 & 119.7 \\
\hline C43-C44-H44 & 119.7 \\
\hline C50-C45-C46 & $115.8(2)$ \\
\hline C50-C45-C 31 & $122.2(2)$ \\
\hline C46-C45-C31 & $122.02(19)$ \\
\hline C47-C46-C45 & $122.2(2)$ \\
\hline C47-C46-H46 & 118.9 \\
\hline C45-C46-H46 & 118.9 \\
\hline C46-C47-C48 & $120.5(2)$ \\
\hline C46-C47-H47 & 119.7 \\
\hline C48-C47-H47 & 119.7 \\
\hline C49-C48-C47 & $118.5(2)$ \\
\hline C49-C48-H48 & 120.8 \\
\hline C47-C48-H48 & 120.8 \\
\hline C48-C49-C50 & $120.7(2)$ \\
\hline C48-C49-H49 & 119.7 \\
\hline C50-C49-H49 & 119.7 \\
\hline C49-C50-C45 & $122.3(2)$ \\
\hline C49-C50-H50 & 118.9 \\
\hline C45-C50-H50 & 118.9 \\
\hline C52-C51-C56 & $117.5(2)$ \\
\hline C52-C51-C32 & $121.7(2)$ \\
\hline C56-C51-C32 & $120.8(2)$ \\
\hline C53-C52-C51 & $121.3(3)$ \\
\hline C53-C52-H52 & 119.3 \\
\hline C51-C52-H52 & 119.3 \\
\hline C53-C54-C55 & $119.2(3)$ \\
\hline C53-C54-H53 & 120.4 \\
\hline C55-C54-H53 & 120.4 \\
\hline C54-C53-C52 & $120.8(3)$ \\
\hline C54-C53-H53 & 119.6 \\
\hline C52-C53-H53 & 119.6 \\
\hline C54-C55-C56 & $120.6(3)$ \\
\hline C54-C55-H54 & 119.7 \\
\hline C56-C55-H54 & 119.7 \\
\hline C55-C56-C51 & $120.5(2)$ \\
\hline C55-C56-H55 & 119.7 \\
\hline C51-C56-H55 & 119.7 \\
\hline
\end{tabular}

DOW RESTRICTED - For internal use only 
Table 22. Anisotropic displacement parameters $\left(\AA^{2} \mathrm{x} 10^{3}\right)$ for 13. The anisotropic displacement factor exponent takes the form: $-2 \pi^{2}\left[h^{2} a^{* 2} U^{11}+\ldots+2 h k a^{*} b^{*} U^{12}\right]$

\begin{tabular}{|c|c|c|c|c|c|c|}
\hline & $\mathrm{U}^{11}$ & $\mathrm{U}^{22}$ & $\mathrm{U}^{33}$ & $\mathrm{U}^{23}$ & $\mathrm{U}^{13}$ & $\mathrm{U}^{12}$ \\
\hline $\mathrm{Zr}$ & $27(1)$ & $30(1)$ & $31(1)$ & $1(1)$ & $2(1)$ & $-3(1)$ \\
\hline N1 & $23(1)$ & $36(1)$ & $30(1)$ & $0(1)$ & $2(1)$ & $-1(1)$ \\
\hline N2 & $23(1)$ & $30(1)$ & $33(1)$ & $0(1)$ & $4(1)$ & $-1(1)$ \\
\hline $\mathrm{C} 1$ & $27(1)$ & $38(1)$ & $31(1)$ & $4(1)$ & $3(1)$ & $-2(1)$ \\
\hline $\mathrm{C} 2$ & $25(1)$ & $33(1)$ & $34(1)$ & $3(1)$ & $3(1)$ & $-1(1)$ \\
\hline C3 & $30(1)$ & $54(1)$ & $65(2)$ & $24(1)$ & $-1(1)$ & $-9(1)$ \\
\hline C6 & $23(1)$ & $35(1)$ & $40(1)$ & $9(1)$ & $-1(1)$ & $-3(1)$ \\
\hline $\mathrm{C} 7$ & $26(1)$ & $37(1)$ & $45(1)$ & $8(1)$ & $5(1)$ & $0(1)$ \\
\hline $\mathrm{C} 8$ & 24(1) & $48(1)$ & $63(1)$ & $13(1)$ & $6(1)$ & $2(1)$ \\
\hline C9 & $26(1)$ & $54(1)$ & $68(2)$ & $20(1)$ & $-7(1)$ & $-2(1)$ \\
\hline $\mathrm{C} 10$ & $37(1)$ & $46(1)$ & $55(1)$ & $12(1)$ & $-16(1)$ & $-10(1)$ \\
\hline C11 & $35(1)$ & $35(1)$ & $43(1)$ & $8(1)$ & $-6(1)$ & $-4(1)$ \\
\hline $\mathrm{C} 12$ & $32(1)$ & $47(1)$ & $44(1)$ & $0(1)$ & $8(1)$ & $3(1)$ \\
\hline C13 & $72(2)$ & $72(2)$ & $46(1)$ & $9(1)$ & $10(1)$ & $-2(1)$ \\
\hline C14 & $58(2)$ & $55(2)$ & $63(2)$ & $-8(1)$ & $9(1)$ & $7(1)$ \\
\hline $\mathrm{C} 15$ & $47(1)$ & $55(1)$ & $40(1)$ & $-4(1)$ & $-7(1)$ & $-1(1)$ \\
\hline C16 & $117(3)$ & $59(2)$ & $92(2)$ & $-22(2)$ & $15(2)$ & $-9(2)$ \\
\hline $\mathrm{C} 17$ & $117(3)$ & $80(2)$ & $59(2)$ & $7(2)$ & $28(2)$ & $-5(2)$ \\
\hline C18 & $26(1)$ & $30(1)$ & $34(1)$ & $2(1)$ & $7(1)$ & $-2(1)$ \\
\hline C19 & $26(1)$ & $36(1)$ & $36(1)$ & $6(1)$ & $6(1)$ & $0(1)$ \\
\hline $\mathrm{C} 20$ & $28(1)$ & $50(1)$ & $52(1)$ & $6(1)$ & $6(1)$ & $2(1)$ \\
\hline $\mathrm{C} 21$ & $37(1)$ & $55(1)$ & $66(2)$ & $1(1)$ & 21(1) & $12(1)$ \\
\hline $\mathrm{C} 22$ & $53(1)$ & $44(1)$ & $53(1)$ & $-10(1)$ & $20(1)$ & $4(1)$ \\
\hline $\mathrm{C} 23$ & $36(1)$ & $35(1)$ & $43(1)$ & $-3(1)$ & $10(1)$ & $-3(1)$ \\
\hline $\mathrm{C} 24$ & $30(1)$ & $47(1)$ & $37(1)$ & $1(1)$ & $1(1)$ & $-2(1)$ \\
\hline $\mathrm{C} 25$ & $88(2)$ & $70(2)$ & $41(1)$ & $7(1)$ & $1(1)$ & $4(2)$ \\
\hline $\mathrm{C} 26$ & 49(1) & $64(2)$ & $61(2)$ & $-9(1)$ & $6(1)$ & $-19(1)$ \\
\hline $\mathrm{C} 27$ & $46(1)$ & $52(1)$ & $46(1)$ & $-18(1)$ & $6(1)$ & $-7(1)$ \\
\hline $\mathrm{C} 28$ & $82(2)$ & $67(2)$ & $69(2)$ & $-19(2)$ & 11(2) & $-33(2)$ \\
\hline C29 & $88(2)$ & $62(2)$ & $47(1)$ & $-18(1)$ & $-1(1)$ & $-4(2)$ \\
\hline C30 & $36(1)$ & $43(1)$ & $53(1)$ & $13(1)$ & $5(1)$ & $2(1)$ \\
\hline C31 & $38(1)$ & $34(1)$ & $41(1)$ & $-1(1)$ & $-2(1)$ & $-2(1)$ \\
\hline C32 & $57(2)$ & $47(1)$ & $44(1)$ & $3(1)$ & $18(1)$ & $-3(1)$ \\
\hline C33 & $24(1)$ & $39(1)$ & $46(1)$ & $8(1)$ & $4(1)$ & $-4(1)$ \\
\hline C34 & $43(1)$ & $55(1)$ & $54(1)$ & $-8(1)$ & $10(1)$ & $-5(1)$ \\
\hline $\mathrm{C} 35$ & $52(2)$ & $36(1)$ & $94(2)$ & $-1(1)$ & $16(1)$ & $5(1)$ \\
\hline C36 & $53(2)$ & $60(2)$ & $70(2)$ & $24(1)$ & $8(1)$ & $7(1)$ \\
\hline C37 & $58(2)$ & $71(2)$ & $49(1)$ & $11(1)$ & $2(1)$ & $-1(1)$ \\
\hline C38 & 47(1) & $44(1)$ & $51(1)$ & $-2(1)$ & $3(1)$ & $-2(1)$ \\
\hline C39 & $25(1)$ & $37(1)$ & $45(1)$ & $4(1)$ & $2(1)$ & $3(1)$ \\
\hline $\mathrm{C} 40$ & $40(1)$ & $50(1)$ & $47(1)$ & $5(1)$ & $0(1)$ & $7(1)$ \\
\hline C41 & $52(2)$ & $70(2)$ & $66(2)$ & $29(1)$ & 18(1) & $18(1)$ \\
\hline $\mathrm{C} 42$ & 43(1) & $51(2)$ & $124(3)$ & $38(2)$ & $28(2)$ & $9(1)$ \\
\hline C43 & $32(1)$ & $39(1)$ & $134(3)$ & $-14(2)$ & $-2(1)$ & $2(1)$ \\
\hline C44 & $35(1)$ & $48(1)$ & $63(1)$ & $-12(1)$ & $-4(1)$ & $10(1)$ \\
\hline $\mathrm{C} 45$ & $36(1)$ & $39(1)$ & $35(1)$ & $-5(1)$ & $-7(1)$ & $-1(1)$ \\
\hline $\mathrm{C} 46$ & $44(1)$ & $42(1)$ & $43(1)$ & $-4(1)$ & $0(1)$ & $6(1)$ \\
\hline C47 & $53(1)$ & $57(2)$ & $43(1)$ & $5(1)$ & $3(1)$ & $7(1)$ \\
\hline $\mathrm{C} 48$ & 51(1) & $72(2)$ & $39(1)$ & $-7(1)$ & $4(1)$ & $10(1)$ \\
\hline C49 & $68(2)$ & $57(2)$ & $51(1)$ & $-19(1)$ & $1(1)$ & $15(1)$ \\
\hline $\mathrm{C} 50$ & $61(2)$ & $40(1)$ & $48(1)$ & $-8(1)$ & $-3(1)$ & $4(1)$ \\
\hline
\end{tabular}




\begin{tabular}{llllccc} 
C51 & $48(1)$ & $41(1)$ & $33(1)$ & $8(1)$ & $18(1)$ & $7(1)$ \\
C52 & $59(2)$ & $49(1)$ & $58(2)$ & $16(1)$ & $14(1)$ & $17(1)$ \\
C54 & $63(2)$ & $88(2)$ & $70(2)$ & $8(2)$ & $-7(1)$ & $-16(2)$ \\
C53 & $51(2)$ & $87(2)$ & $82(2)$ & $33(2)$ & $-3(1)$ & $11(2)$ \\
C55 & $87(2)$ & $47(2)$ & $82(2)$ & $-6(1)$ & $27(2)$ & $-9(2)$ \\
C56 & $52(1)$ & $43(1)$ & $66(2)$ & $9(1)$ & $26(1)$ & $8(1)$ \\
\hline
\end{tabular}

Table 23. Hydrogen coordinates ( x 104) and isotropic displacement parameters $\left(\AA^{2} \times 10^{3}\right)$ for $\mathbf{1 3}$.

\begin{tabular}{|c|c|c|c|c|}
\hline & $\mathrm{x}$ & $\mathrm{y}$ & $\mathrm{z}$ & $\mathrm{U}(\mathrm{eq})$ \\
\hline $\mathrm{H} 2 \mathrm{~A}$ & 196 & -3774 & -6503 & 37 \\
\hline H2B & 141 & -4290 & -7197 & 37 \\
\hline H3A & -2369 & -3989 & -6652 & 60 \\
\hline H3B & -2051 & -4473 & -7320 & 60 \\
\hline H8 & -4413 & -2268 & -6925 & 54 \\
\hline H9 & -5074 & -2770 & -7982 & 59 \\
\hline H10 & -4066 & -3371 & -8787 & 55 \\
\hline H12 & -1870 & -2246 & -6374 & 49 \\
\hline H13A & -3648 & -2683 & -5694 & 95 \\
\hline H13B & -2666 & -2457 & -5268 & 95 \\
\hline H13C & -2689 & -3177 & -5749 & 95 \\
\hline H14A & -2598 & -1226 & -5857 & 88 \\
\hline H14B & -3644 & -1426 & -6203 & 88 \\
\hline $\mathrm{H} 14 \mathrm{C}$ & -2776 & -1164 & -6709 & 88 \\
\hline H15 & -1493 & -3742 & -8536 & 57 \\
\hline H16A & -3203 & -4292 & -9284 & 134 \\
\hline H16B & -2739 & -4672 & -8582 & 134 \\
\hline H16C & -2130 & -4638 & -9310 & 134 \\
\hline H17A & -1678 & -2705 & -9278 & 127 \\
\hline H17B & -2615 & -3060 & -9668 & 127 \\
\hline $\mathrm{H} 18 \mathrm{C}$ & -1556 & -3413 & -9767 & 127 \\
\hline $\mathrm{H} 20$ & 3874 & -3616 & -7220 & 52 \\
\hline $\mathrm{H} 21$ & 3923 & -4406 & -8199 & 63 \\
\hline $\mathrm{H} 22$ & 2482 & -4692 & -8828 & 59 \\
\hline $\mathrm{H} 24$ & 1767 & -2737 & -6504 & 45 \\
\hline $\mathrm{H} 25 \mathrm{~A}$ & 3318 & -3621 & -5922 & 99 \\
\hline $\mathrm{H} 25 \mathrm{~B}$ & 2185 & -3837 & -5889 & 99 \\
\hline $\mathrm{H} 25 \mathrm{C}$ & 2582 & -3142 & -5459 & 99 \\
\hline H26A & 3053 & -2037 & -7030 & 87 \\
\hline $\mathrm{H} 26 \mathrm{~B}$ & 3842 & -2523 & -6604 & 87 \\
\hline $\mathrm{H} 26 \mathrm{C}$ & 3108 & -2017 & -6168 & 87 \\
\hline $\mathrm{H} 27$ & 80 & -3983 & -8513 & 58 \\
\hline $\mathrm{H} 28 \mathrm{~A}$ & 302 & -5172 & -8002 & 109 \\
\hline $\mathrm{H} 28 \mathrm{~B}$ & 872 & -5416 & -8708 & 109 \\
\hline $\mathrm{H} 28 \mathrm{C}$ & -264 & -5210 & -8763 & 109 \\
\hline H29A & 1235 & -4536 & -9674 & 99 \\
\hline H29B & 973 & -3695 & -9592 & 99 \\
\hline
\end{tabular}




\begin{tabular}{lrrrl} 
H29C & 121 & -4274 & -9740 & 99 \\
H30A & -1870 & -1813 & -8268 & 53 \\
H30B & -1699 & -1437 & -7499 & 53 \\
H31A & 1390 & -1607 & -6859 & 45 \\
H31B & 662 & -976 & -7113 & 45 \\
H32A & 759 & -2658 & -9102 & 59 \\
H32B & 137 & -1923 & -9241 & 59 \\
H34 & -1268 & -5616 & -7113 & 61 \\
H35 & -835 & -6546 & -6285 & 72 \\
H36 & -744 & -6284 & -5057 & 73 \\
H37 & -1086 & -5130 & -4640 & 71 \\
H38 & -1513 & -4217 & -5442 & 57 \\
H40 & -1495 & -1167 & -9364 & 55 \\
H41 & -1144 & -99 & -9954 & 75 \\
H42 & -585 & 908 & -9316 & 86 \\
H43 & -458 & 856 & -8052 & 82 \\
H44 & -834 & -226 & -7438 & 58 \\
H46 & 363 & -2582 & -6001 & 52 \\
H47 & -413 & -2617 & -4895 & 61 \\
H48 & -1065 & -1551 & -4393 & 65 \\
H49 & -910 & -454 & -5024 & 70 \\
H50 & -152 & -421 & -6134 & 60 \\
H52 & 2488 & -2566 & -8723 & 66 \\
H53 & 3753 & -620 & -8318 & 88 \\
H53 & 3876 & -1872 & -8493 & 88 \\
H54 & 2216 & -58 & -8417 & 86 \\
H55 & 823 & -734 & -8734 & 64 \\
& & & & \\
\hline
\end{tabular}

